$$
\text { UNIVERSIDADE DE SÃO PAULO }
$$

FACULDADE DE MEDICINA DE RIBEIRÃO PRETO

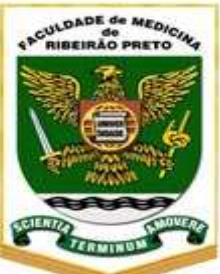

"POLIMORFISMOS NOS RECEPTORES DE ADENOSINA, SUAS ASSOCIAÇÕES COM CARACTERÍSTICAS FISIOPATOLÓGICAS E AVALIAÇÃO DE COMPONENTES NA BIOSSÍNTESE DA ADENOSINA EM PACIENTES COM DOENÇA FALCIFORME"

Carolina Dias Carlos

RIBEIRÃO PRETO 


\author{
UNIVERSIDADE DE SÃO PAULO
}

FACULDADE DE MEDICINA DE RIBEIRÃO PRETO

\title{
"POLIMORFISMOS NOS RECEPTORES DE ADENOSINA, SUAS ASSOCIAÇÕES COM CARACTERÍSTICAS FISIOPATOLÓGICAS E AVALIAÇÃO DE COMPONENTES NA BIOSSÍNTESE DA ADENOSINA EM PACIENTES COM DOENÇA FALCIFORME"
}

\section{Carolina Dias Carlos}

Dissertação Apresentada à Faculdade de Medicina de Ribeirão Preto da Universidade de São Paulo para Obtenção do Título de Mestre em Genética.

Área de Concentração: Genética

Orientador: Prof. Dr. Rodrigo Alexandre Panepucci

RIBEIRÃO PRETO 
AUTORIZO A DIVULGAÇÃO TOTAL OU PARCIAL DESTE TRABALHO, POR QUALQUER MEIO CONVENCIONAL OU ELETRÔNICO, PARA FINS DE ESTUDO E PESQUISA, DESDE QUE CITADA A FONTE.

\section{FICHA CATALOGRÁFICA}

Preparada pela Biblioteca Central do Campus Administrativo de Ribeirão Preto/USP

Dias-Carlos, Carolina

POLIMORFISMOS NOS RECEPTORES DE ADENOSINA, SUAS ASSOCIAÇÕES

CARACTERÍSTICAS FISIOPATOLÓGICAS E AVALIAÇÃO DE COMPONENTE BIOSSÍNTESE DA ADENOSINA EM PACIENTES COM DOENÇA FALCIFORME. 156 p.:il. ; $30 \mathrm{~cm}$

Dissertação de Mestrado apresentada à Faculdade Medicina de Ribeirão Preto/USP. Área de concentração: Genética.

Orientador: Panepucci, Rodrigo Alexandre.

1. Doença Falciforme 2. Polimorfismos 3. Adenosina deaminase 4. Receptores de adenosina. 


\section{FOLHA DE APROVAÇÃO}

Carolina Dias Carlos

POLIMORFISMOS NOS RECEPTORES DE ADENOSINA, SUAS ASSOCIAÇÕES COM CARACTERÍSTICAS FISIOPATOLÓGICAS E AVALIAÇÃO DE COMPONENTES NA BIOSSÍNTESE DA ADENOSINA EM PACIENTES COM DOENÇA FALCIFORME.

Dissertação Apresentada à Faculdade de Medicina de Ribeirão Preto da Universidade de São Paulo para Obtenção do Título de Mestre em Ciências.

Área de Concentração: Genética

Aprovado em:

Banca Examinadora

Prof. Dr. Rodrigo Alexandre Panepucci

Instituição: Assinatura

Prof. Dr.

Instituição: Assinatura

Prof. Dr.

Instituição: Assinatura 
"O Progresso humano nunca corre sobre as rodas da inevitabilidade; ele vem através dos esforços incansáveis dos homens que desejam colaborar com Deus, e sem esse trabalho árduo, o próprio tempo torna-se um aliado das forças da estagnação social. Temos que usar o tempo criativamente, sabendo que é sempre certo o tempo de fazer o que é certo"

MARTIN LUTHER KING JR. 


\section{AGRADECIMENTOS}

À Universidade de São Paulo de Ribeirão Preto, ao Hospital das Clínicas e ao Hemocentro pelo suporte técnico-científico;

À FAPESP, pela concessão de dois anos de bolsa de estudos e reserva técnica permitindo viajens a congressos que contribuíram muito para minha formação acadêmica;

Ao curso de Pós-Graduação em Genética, pela oportunidade de realização do meu Mestrado;

Aos professores credenciados pelo curso que ministraram as disciplinas as quais pude participar e que muito contribuíram para minha formação;

Às secretárias do Curso de Pós Graduação em Genética, Susie, Maria Aparecida e Silvia por toda prestatividade de informações durante o período em que estive matriculada neste curso.

Ao meu orientador Rodrigo A. Panepucci, pela oportunidade oferecida de crescimento profissional e pessoal, pela amizade e orientações essenciais a esse trabalho e à minha formação.

As funcionárias do laboratório, Marli, Amélia, Cláudia, Júlia por estarem sempre prontas a ajudar no que fosse preciso para o desenvolvimento deste trabalho;

Aos amigos que me receberam de coração aberto, Francisco pelos ensinamentos práticos de laboratório e palavra amiga nas horas difíceis e agradeço em especial ao Felipe que participou de forma ativa no projeto ajudando tanto na prática de experimentos, como dicas para um melhor desenvolvimento deste trabalho sempre com toda atenção e paciência;

Aos amigos "Turquinho", Lucila e Josiane pela convivência ajuda e companherismo;

À professora Dra. Simone Kashima Haddad pela disponibilidade de seu laboratório e interesse no envolvimento deste projeto, inclusive para a formação do Banco de amostras de doença falciforme do Hemocentro.

A todos os alunos e funcionários do Laboratório de Biologia Molecular do Centro Regional de Hematologia de Ribeirão Preto em especial Virginia Mara Wagatsuma e Evandra Strazza Rodrigues, que me acompanharam desde a minha chegada com o processamento das amostras; 
Aos Funcionários do Hemocentro Patrícia Vianna Bonini Palma, Camila, nas análises de citometria de fluxo, a Adriana Aparecida Marques e Israel Tojal Silva, na realização e análise do seqüenciamento;

À médica Ana Cristina Silva Pinto pela atenção despendida para que fosse possível a coleta de sangue no ambulatório do Hemocentro;

À equipe de enfermagem do Hemocentro, em especial Carol e Fernando, por suas habilidade e atenção na coleta de sangue.

Aos amigos Marcelo Luizon, Ronyere e a amiga Carla, me ajudando de forma imprescindível na operação e interpretação de programas de análise estatística;

Às grandes amizades que conquistei nesta cidade, Mariane Fráguas pelas longas conversas e trocas de idéias e ótima convivência, à amiga Mariane Benício pessoa mais prestativa que conheci, além de contar com sua amizade, pude contar com sua ajuda e dicas imprescindíveis e palavra amiga de sempre. E à amiga Sabrina pela companhia agradável de toda e qualquer hora!

À minha amiga de longa data, Bianca que acabou vindo pra "ribs" e com certeza foi um apoio maior que tive durante o último ano de mestrado, contando sempre com sua presença importante;

Aos meus pais, pela dedicação em me oferecer sempre o melhor que puderam, pela paciência de me escutarem, por toda preocupação e apoio incondicional, por tuuuudooo!!!!!

A todos, que de alguma forma contribuíram e conviverem comigo, meus sinceros agradecimentos!!!!

A Deus por ter me permitido chegar até aqui, sempre me ajudando a vencer os obstáculos. 
DIAS-CARLOS, C. Polimorfismos nos receptores de adenosina, suas associações com diferentes características fisiopatológicas e avaliação de componentes na biossíntese da adenosina em pacientes com doença falciforme. Dissertação de Mestrado em Genética. Faculdade de Medicina de Ribeirão Preto, Universidade de São Paulo. Ribeirão Preto, 2011.

\section{RESUMO}

$\mathrm{Na}$ Anemia Falciforme em situações de baixa tensão de oxigênio, a hemoglobina mutante $S(\mathrm{HbS})$ sofre polimerização promovendo a falcização das hemácias, que podem aderir ao endotélio vascular, causando a oclusão de vasos (VO) e isquemia tecidual (crises dolorosas) que caracterizam o quadro clínico da doença. Além disso, os pacientes falciformes apresentam outras manifestações clínicas como o priapismo, alterações ósseas, certas complicações pulmonares entre outros. Além das células eritróides, células endoteliais, leucócitos e plaquetas também desempenham um papel fundamental na fisiopatologia da anemia falciforme. A hidroxiuréia (HU), na anemia falciforme, aumenta a produção de hemoglobina fetal $(\mathrm{HbF})$ em células eritróides, reduzindo a polimerização da $\mathrm{HbS}$, diminuindo os sintomas clínicos dos pacientes. $\mathrm{O}$ aumento da $\mathrm{HbF}$, no entanto, não implica necessariamente na melhora clínica, indicando desta forma a potencial ação da HU sobre outros processos. Estudos recentes vêm relacionando priapismo e asma com elevados níveis de adenosina. Devido a esta importância da adenosina relacionada a patologias comuns a $\mathrm{AF}$, tivemos como objetivo identificar polimorfismos em genes de receptores de adenosina e na adenosina deaminase e verificar a possível associação entre as manifestações clínicas, além de investigar o papel da HU na modulação de marcadores envolvido na síntese e degradação da adenosina. Foram analisados diversos sítios polimórficos nos genes que codificam ADORA1, ADORA 2b, ADORA 3 e ADA, seguindo com a genotipagem em pacientes com AF, comparando afetados e não afetados. Em adição foi avaliada a expressão diferencial de mRNA de ADA pela $\mathrm{HU}$ em monócitos destes pacientes, comparando tratados e não tratados e também avaliamos por citometria de fluxo a modulação de marcadores de superfície CD39, CD73 e CD26, pela HU. As análises estatísticas foram realizadas utilizando os softwares GenePop 3.4 para análises de associação, cálculo do HWE, GraphPad Prism 5, Arlequin para identificação de desequilíbrio de ligação, haplótipos, heterozigozidade e SAS 9.13 para associação dos haplótipos as características. Os resultados mostraram que os pacientes sob tratamento com $\mathrm{HU}$ apresentaram um aumento da expressão de mRNA de ADA, aumento da expressão de CD26 em monócitos e diminuição de CD39 em linfócitos. Sem alterações significativas em relação a CD73. Encontramos também um aumento da freqüência do alelo $T$ do SNP (rs1685103) presente no gene de ADORA 1 associado com pacientes afetados com síndrome torácica aguda. Apesar de não ter sido estatisticamente significante, concorda com dados da literatura. No gene ADORA 2B, 
verificamos associação do SNP 1007 C>T no desenvolvimento de STA indicando $O$ alelo $T$ como fator de risco e o alelo $C$ para alterações ósseas. Para o SNP 968 G>T houve associação com alterações ósseas. Na análise haplotípica entre os SNPs 968 G>T e 1007 C>T encontramos associação dos haplótipos ht2 e ht3 com STA, como fator de risco, ht2 para hipertensão pulmonar. ht1 para priapismo, alterações ósseas e estenose/AVC. Os haplótipos formados pelos três SNPs 968 G>T, 1007 C>T e rs16851030, encontramos associação entre ht1, ht3 e ht 4 entre os afetados com priapismo, caracterizando-o como haplótipo de risco e também ht1 e ht6 associados à estenose/AVC. Concluímos, que a hidroxiuréia participa na modulação da expressão da adenosina deaminase, de CD26 em monócitos e CD39 em linfócitos. Além disso, mostrou-se a importância de sítios polimórfico presente no gene ADORA 2B e ADORA1 envolvido na fisiopatologia das manifestações clínicas da doença falciforme. Associações dos SNPs em ADORA 1 e ADA, devem ser melhor estudados em um número maior de pacientes. A determinação destes polimorfismos associados com diferentes características clínicas pode levar a um melhor entendimento dos processos fisiopatológicos da anemia falciforme, levando à identificação de pacientes de risco, possibilitando um manejamento racional dos mesmos, em termos de cuidados específicos, ou mesmo à determinação de alvos para o desenvolvimento de terapias alternativas.

Palavras-chave: Polimorfismo Gênico, receptor de adenosina, adenosina deaminase, Doença Falciforme. 
DIAS-CARLOS, C. Polymorphism in adenosine receptors and their associations with different pathophysiological characteristics and evaluation of components in the biosynthesis of adenosine in patients with sickle cell disease.Master's Thesis in Genetics. Faculty of Medicine of Ribeirao Preto, Universidade de São Paulo. Ribeirão Preto, 2011.

\section{ABSTRACT}

In sickle cell disease in low oxygen tension, mutant hemoglobin $S(\mathrm{HbS})$ undergoes polymerization promoting sickling of red blood cells that can adhere to vascular endothelium, causing vessel occlusion (VO) and tissue ischemia (painful crises) that characterize the clinical disease. In addition, sickle cell patients have other clinical manifestations such as priapism, bone disorders, certain pulmonary complications among others. In addition to the erythroid cells, endothelial cells, white cells and platelets also play a key role in the pathophysiology of sickle cell anemia. Hydroxyurea (HU) in sickle cell anemia, increases the production of fetal hemoglobin $(\mathrm{HbF})$ in erythroid cells, reducing the $\mathrm{HbS}$ polymerization, reducing the clinical symptoms of patients. The increase in $\mathrm{HbF}$, however, does not necessarily imply clinical improvement, thus indicating the potential effects of HU on other processes. Recent studies relating asthma and priapism with high levels of adenosine. Due to this importance of adenosine-related pathologies common to AF, we aimed to identify gene polymorphisms in adenosine receptors and adenosine deaminase and verify the possible association between clinical manifestations, and to investigate the role of $\mathrm{HU}$ in the modulation of markers involved synthesis and degradation of adenosine. We analyzed several polymorphic sites in genes that encode ADORA1, ADORA 2b, 3 and ADORA ADA, according to the genotype in patients with $A F$, comparing affected and unaffected. In addition we assessed the differential expression of ADA mRNA by HU in monocytes of these patients, comparing treated and untreated, and also evaluated by flow cytometry modulation of surface markers CD39, CD73 and CD26 by HU. Statistical analysis was performed using the software GenePop 3.4 for association analysis, calculation of HWE, GraphPad Prism 5, Arlequin for identification of linkage disequilibrium, haplotypes, heterozygosity and SAS 9.13 for association of haplotypes features. The results showed that patients treated with $\mathrm{HU}$ showed an increase in mRNA expression of ADA, increased expression of CD26 on monocytes and decreased CD39 on lymphocytes. No significant changes in relation to CD73. We also found an increased frequency of allele $T$ (SNP rs1685103) present in a gene associated with ADORA affected patients with acute chest syndrome. Although not statistically significant, agrees with literature data. ADORA 2B gene, we found association of the SNP $1007 \mathrm{C}>\mathrm{T}$ in the development of STA indicating the $T$ allele as a risk factor for the $C$ allele and bone changes. For the SNP $968 \mathrm{G}>\mathrm{T}$ was associated with bone disorders. In haplotype analysis between SNPs 968 G> T and 1007 C> T found 
association of haplotypes ht2 and HT3 with STA as a risk factor for pulmonary hypertension ht2. ht1 for priapism, stenosis and bone disorders / stroke. The three haplotypes formed by SNPs $968 \mathrm{G}>\mathrm{T}, 1007 \mathrm{C}>\mathrm{T}$ and rs16851030, we found association between ht1, HT3 and HT4 among those affected with priapism, characterizing it as a risk haplotype and also ht $1 \mathrm{ht} 6$ associated with renal and / AVC. We conclude that hydroxyurea participates in modulating the expression of adenosine deaminase of CD26 on monocytes and CD39 on lymphocytes. Moreover, he showed the importance of polymorphic sites in this gene and ADORA 2B ADORA1 involved in the pathophysiology of clinical manifestations of sickle cell disease. Associations of SNPs in ADORA 1 and ADA should be better studied in a larger number of patients. The determination of these polymorphisms associated with different clinical characteristics can lead to a better understanding of the pathophysiological processes of sickle cell anemia, leading to the identification of patients at risk, enabling a rational handling of the same in terms of specific care, or even the determination of targets for the development of alternative therapies.

Keywords: Gene polymorphism, adenosine receptors, adenosine deaminase, Sickle Cell Disease. 


\section{SUMÁRIO}

1. INTRODUCÃO

1.1. Anemia Falciforme e outras Doenças Falciformes .................................................... 19

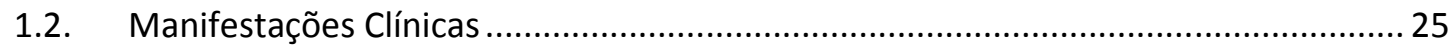

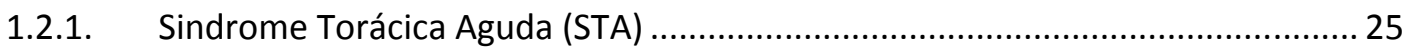

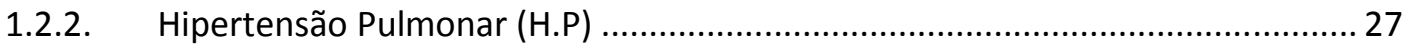

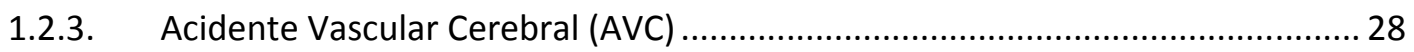

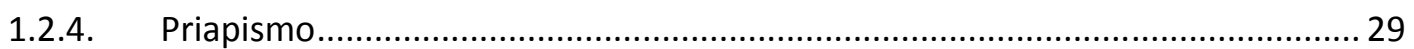

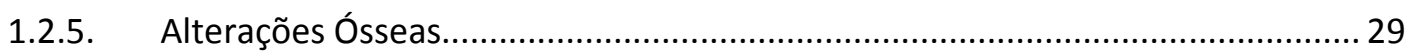

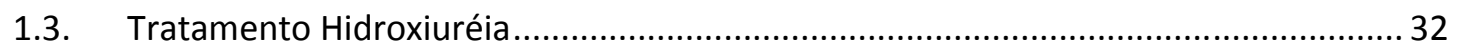

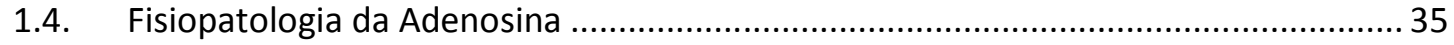

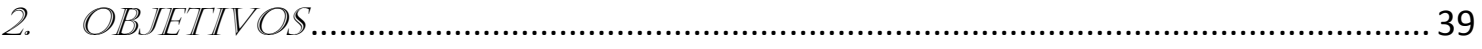

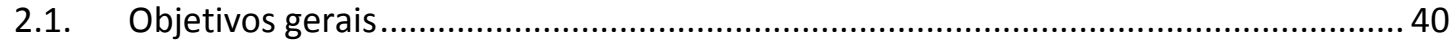

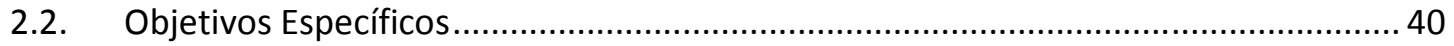

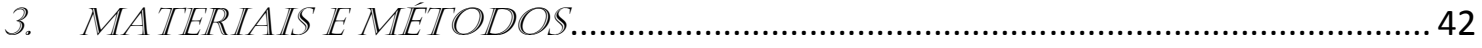

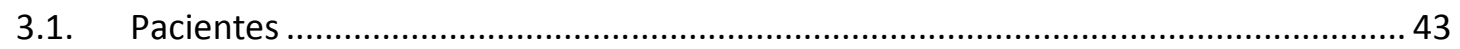

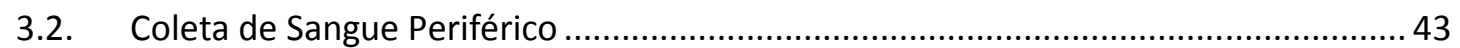

3.3. Extração, Quantificação e Armazenamento das Amostras de DNA............................. 43

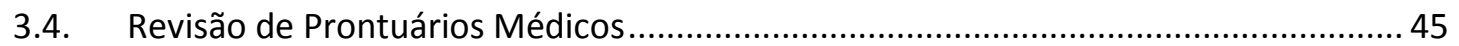

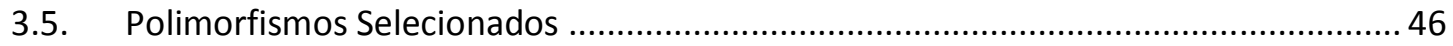

3.6. Desenho de Sondas para Discriminação Alélica................................................................ 47

3.7. Desenho de iniciadores para seqüenciamento ............................................................ 49

3.8. Padronização das reações de PCR ........................................................................... 50

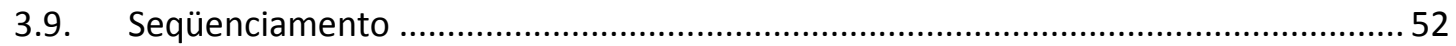

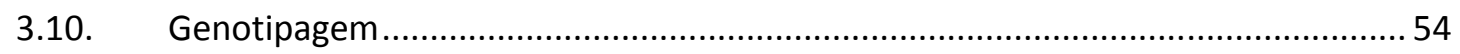

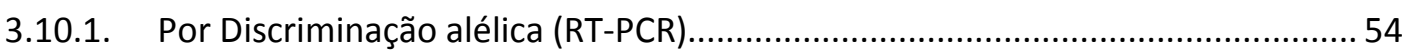

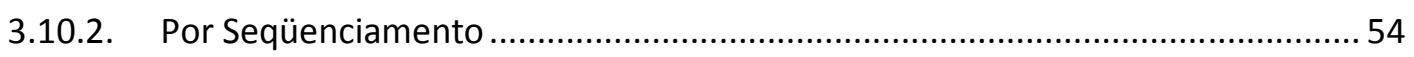

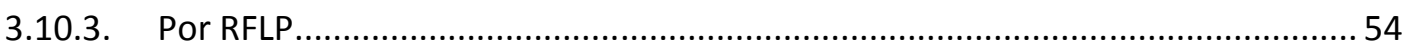

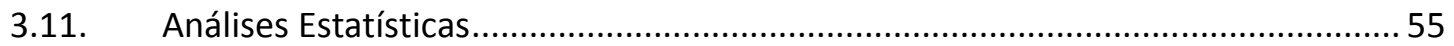

3.12. Avaliação da modulação de componentes envolvidos na biossíntese da adenosina pela Hidroxiuréia em pacientes com doença falciforme ................................................... 58

3.12.1. Isolamento de Monócitos do Sangue Periférico …………................................. 58

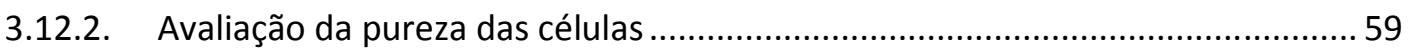

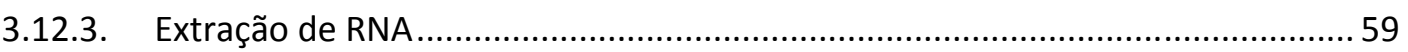


3.12.4. Quantificação do RNA

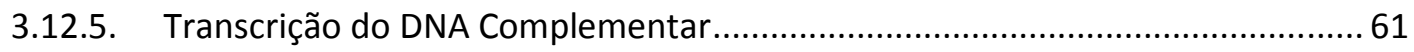

3.12.6. Avaliação dos Níveis Transcricicionais da ADA (RT-PCR)......................................61

3.12.7. Avaliação da modulação da expressão de CD39, CD73 e CD26 em linfócitos e monócitos de paciente de AF, frente ao tratamento com HU...........................................62 62

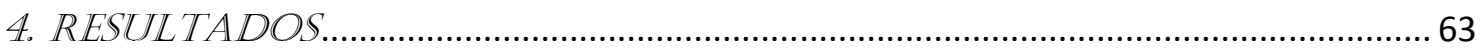

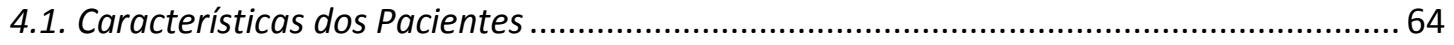

4.2. Avaliação das Potenciais Associações entre os Polimorfismos Estudados e as Manifestações Clínicas da Doença Falciforme

4.3. Detecção de polimorfismos no gene ADORA $2 B$ e suas associações com as manifestações

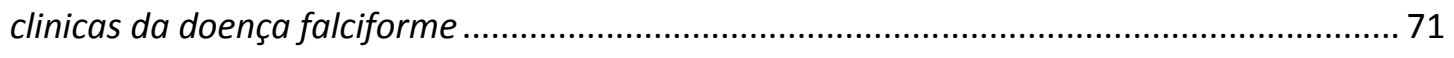

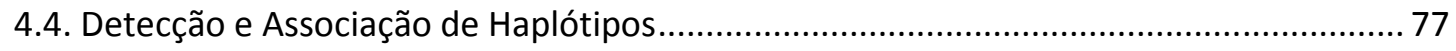

4.5. Modulação de componentes envolvidos na biossíntese da adenosina pela Hidroxiuréia em pacientes com doença falciforme

4.5.1. Avaliação do Perfil transcricional da ADA em pacientes tratados ou não com Hidroxiuréia.

4.5.2. Avaliação da modulação da expressão de CD39, CD73 e CD26 em linfócitos e monócitos de paciente falciformes, frente ao tratamento com $\mathrm{HU}$.

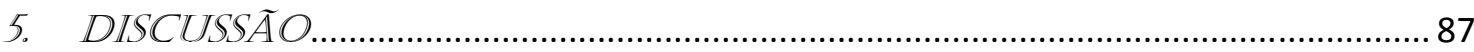

5.1. Polimorfismo do gene de receptor de adenosina A1 .................................................... 88

5.2. Polimorfismo do gene de receptor de adenosina A3................................................. 96

5.3. Polimorfismo do gene de receptor de adenosina $A 2 B$.............................................. 98

5.4. Polimorfismo do gene da adenosina deaminase ….................................................... 111

5.5. Modulação dos componentes envolvidos na síntese e degradação da adenosina pela hidroxiuréia em pacientes falciformes...................................................................... 117

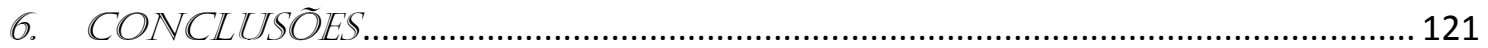

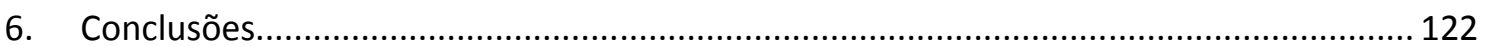

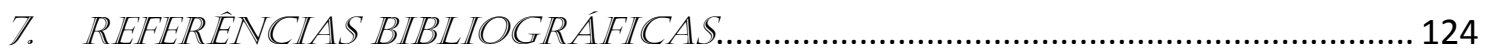

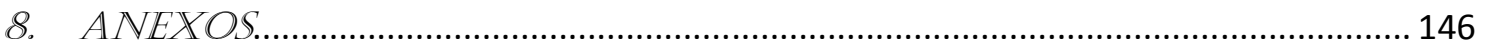

8.1. Anexo 1. Termo de Consentimento Livre e Esclarecido............................................. 147

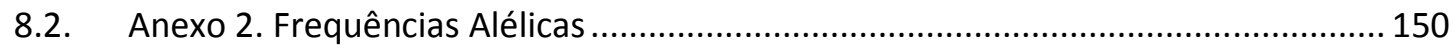

Freqüências alélicas dos polimorfismos nos genes ADORA1,ADORA 2B, ADORA 3 e ADA para STA, HP, priapismo, alterações ósseas e estenose/AVC e suas probabilidades de associação

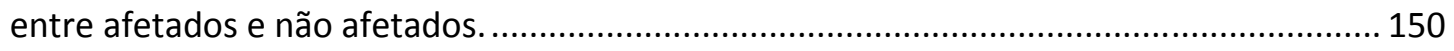

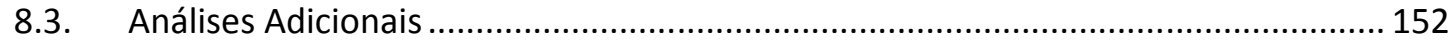





\section{LISTA DE FIGURAS}

Figura 1. Alteração da membrana de hemácias por polímeros de hemoglobina

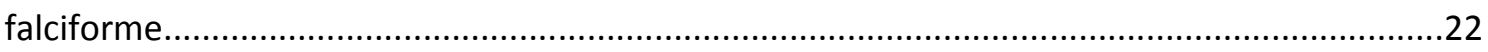

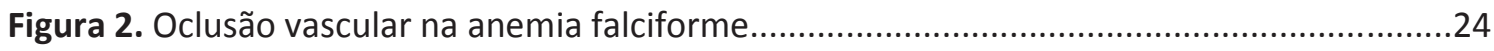

Figura 3. Complicações da doença falciforme por idade..........................................................31

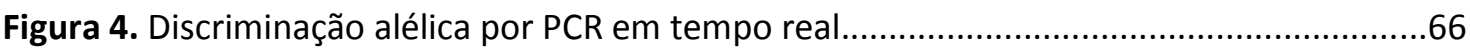

Figura 5. Géis de agarose com resultados representativos da genotipagem realizada por RFLP para o polimorfismo ADA*2 66

Figura 6. Cromatograma do seqüenciamento com os polimorfismos + $968 \mathrm{G}>\mathrm{T}$ identificado no éxon 1 do gene ADORA 2B. .71

Figura 7. Cromatograma do seqüenciamento com os polimorfismos $+1007 \mathrm{C}>\mathrm{T}$ identificado no éxon 1 do gene ADORA 2B. .72

Figura 8. Avaliação por citometria de fluxo da pureza dos monócitos obtidas por seleção positiva.

Figura 9. Análise de expressão gênica relativa da adenosina deaminase por PCR em tempo real.

Figura 10. EXPRESSÃO DE CD26, CD39 E CD73 em monócitos e linfócitos por citometria de fluxo em pacientes com doença falciforme sob o uso da hidroxiuréia.

Figura 11. Modelo do trabalho da adenosina mediando a sinalização intracelular em corpos cavernosos.

Figura 12. Como células T induzem osteoclastogêne na artrite autoimune. 107

Figura 13. Metabolismo da adenosina. 118 


\section{LISTA DE TABELAS}

Tabela 1. Descrição dos polimorfismos selecionados para o estudo de associação com as manifestações clínicas da Anemia Falciforme.

Tabela 2. Sondas selecionadas para a discriminação alélica por PCR em tempo real. .48

Tabela 3. Iniciadores para amplificação da região polimórfica G22A do gene da adenosina deaminase. 48

Tabela 4. Iniciadores desenhados para o seqüenciamento do éxon 1 e 2 do gene ADORA 2B...50

Tabela 5. Condições de amplificação de PCR para a região polimórfica do gene ADA. .51

Tabela 6. Condição de amplificação de PCR para o seqüenciamento do gene ADORA 2B .52

Tabela 7. Condições de amplificação de PCR para análise dos fragmentos dos éxons do gene ADORA 2B no seqüenciador automático MegaBACE 1000. 53

Tabela 8. Características demográficas, clínicas e laboratoriais da população em estudo. 64

Tabela 9. Freqüência genotípica dos polimorfismos nos genes ADORA1 ADORA 3 e ADA para Síndrome Torácica Aguda e suas probabilidades de associação entre afetados e não afetados. 67

Tabela 10. Freqüência alélica dos polimorfismos nos genes ADORA1 ADORA 3 e ADA para Síndrome Torácica Aguda e suas probabilidades de associação entre afetados e não afetados. 68

Tabela 11. Freqüência genotípica dos polimorfismos nos genes ADORA1 ADORA 3 e ADA para priapismo e suas probabilidades de associação entre afetados e não afetados..

Tabela 12. Freqüência genotípica dos polimorfismos nos genes ADORA1 ADORA 3 e ADA para alterações ósseas e suas probabilidades de associação entre afetados e não afetados.

Tabela 13. Freqüência genotípica dos polimorfismos nos genes ADORA1 ADORA 3 e ADA para estenose/AVC e suas probabilidades de associação entre afetados e não afetados...

Tabela 14. Freqüência alélica dos polimorfismos no gene ADORA 2B para síndrome torácica aguda e suas probabilidades de associação entre afetados e não afetados.

Tabela 15. Freqüência genotípica dos polimorfismos no gene ADORA 2B para síndrome torácica aguda e suas probabilidades de associação entre afetados e não afetados.

Tabela 16. Freqüência genotípica dos polimorfismos no gene ADORA 2B para hipertensão pulmonar e suas probabilidades de associação entre afetados e não afetados.

Tabela 17. Freqüência genotípica dos polimorfismos no gene ADORA 2B para priapismo e suas probabilidades de associação entre afetados e não afetados. 
Tabela 18. Freqüência genotípica dos polimorfismos no gene ADORA 2B para alterações ósseas e suas probabilidades de associação entre afetados e não

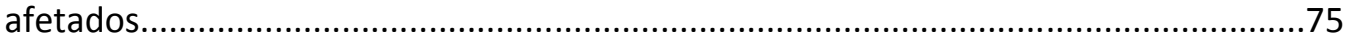

Tabela 19. Freqüência genotípica dos polimorfismos no gene ADORA 2B para estenose/AVC e suas probabilidades de associação entre afetados e não afetados.

Tabela 20. Diversidade Genética para todas as manifestações clínicas obtidas a partir dos SNP 968 G>T e 1007 C>T do gene ADORA 2B. Heterozigosidade observada (Ho), heterozigosidade esperada (He), EHW valores de $p$ obtidos no teste de Equilíbrio de Hardy-Weinberg $(p<0,05)$, DL desequilíbrio de ligação $(p<0,05)$

Tabela 21. Diversidade Genética para todas as manifestações clínicas obtidas a partir dos SNP 968 G>T, 1007 C>T, rs16851030 do gene ADORA 2B e ADORA 1. Heterozigosidade observada (Ho), heterozigosidade esperada (He), EHW valores de $p$ obtidos no teste de Equilíbrio de Hardy-Weinberg $(p<0,05)$, DL desequilíbrio de ligação $(p<0,05)$.

Tabela 22. Haplótipos do gene ADORA $2 B$ e suas freqüências entre os grupos de pacientes falciformes. 81

Tabela 23. Haplótipos dos genes ADORA 1 e ADORA 2B para priapismo e estenose/AVC e suas freqüências entre os grupos de pacientes falciformes. 
1. INTRODUCÃO 


\subsection{Anemia Falciforme e outras Doenças Falciformes}

Embora a Anemia Falciforme (AF) tenha sido descrita há mais de 100 anos (James Herrick, 1904), o entendimento pleno de sua patofisiologia continua longe de ser completo (SERJEANT, 2001).

No Brasil, as regiões de maior prevalência são a Sudeste e a Nordeste, com cerca de $8 \%$ de heterozigotos entre os indivíduos de descendência africana (DI NUZZO et al., 2004; ADORNO et al., 2005). Esta é, no entanto, uma estimativa média, já que, em algumas populações, como na população de Salvador, no Estado da Bahia, a incidência de portadores do traço falcêmico pode ser superior a 10\% (ADORNO et al., 2005). Mais de 50 milhões de pessoas são afetadas por doença falciforme mundialmente (CARTRON \& ELION, 2008).

A definição "Doença Falciforme" engloba um grupo de hemoglobinopatias associadas à substituição de uma única base (20 $G A G \rightarrow G T G)$ na região codificante do gene da cadeia $\beta^{A}$ da hemoglobina $(H b)$, que leva à substituição de um acido glutâmico (polar) por uma valina (hidrofobica) na posição 6 da cadeia $\beta^{A}$ ( $\beta 6$ Glu $\rightarrow$ Val), originando a cadeia variante $\beta^{S}$ (ZAGO et al., 2004; COSTA et al., 2007; WENNING, et al 2007). Os indivíduos heterozigotos para esta mutação apresentam a $\mathrm{Hb} A S\left(\alpha 2 \beta^{A} \beta^{S}\right)$ e são, via de regra, assintomáticos, sendo referido como portadores do traço falcêmico; interessantemente, uma condição que confere resistência à malária (WILLIAMS, 2006; CREARY et al., 2007). Em contraste, a homozigosidade para a mutação na cadeia $\beta$ da origem à Hemoglobina $H b S\left(\alpha 2 \beta^{S} 2\right)$, responsável pela mais severa variante das doenças falciformes, a anemia 
falciforme (CLASTER et al 2003; BERRY et al., 2007), a primeira "doença molecular" descrita por Linus Pauling, em 1949 (FRENETTE et al., 2007).

A associações da $\mathrm{Hb} \mathrm{S}$ com outras variantes estruturais da $\mathrm{Hb}$, como as hemoglobinas $\mathrm{HbC}$ (originadas por diferentes mutações na cadeia $\beta$ ) ou $\mathrm{HbD}$ (originadas por diferentes mutações nas cadeias $\alpha$ ou $\beta$ ), dão origem às Doenças Falciformes, SC, SD; já a interação com as $\beta$-Talassemias, caracterizadas pela ausência de expressão da cadeia $\beta\left(\beta^{0}\right)$ ou redução nos seus níveis de expressão $\left(\beta^{+}\right)$, origina a Doença Falciforme $S-\beta$ talassemia. As DFs SC, SD e as S- $\beta^{+}$talassemias levam a quadros clínicos que podem ter apresentação mais benigna que o da AF, com anemia hemolítica de menor intensidade. Já a associação da $\mathrm{Hb} S$ com a talassemia $\beta^{0}$ (S- $\beta^{0}$ talassemias) leva a manifestações clínicas bastante similares àquelas da AF (CLASTER et al 2003; BERRY et al., 2007).

Em condições normais, as hemácias são capazes de sofrer deformação, o que permite que elas circulem através de vazos estreitos e carreguem $\circ \mathrm{O}_{2}$ para todos os tecidos do corpo. Quando a $\mathrm{Hb} S$ passa para a forma desoxigenada, a valina hidrofóbica (presente no lugar do ácido glutâmico polar) é exposta na superfície da cadeia $\beta^{S}$, levando à polimerização da $\mathrm{Hb} S$ por meio de interações intermoleculares hidrofóbicas e à falcilização das hemácias (MADIGAN et AL., 2006; VEKILOV, 2007). Estas alterações tornam estes eritrócitos rígidos e não deformáveis, o que contribui para o processo de hemólise crônica, oclusão microvascular com conseqüente isquemia tecidual e disfunções orgânicas, que caracterizam o quadro clínico da doença e comprometem tanto a sobrevida, quanto a qualidade de vida dos pacientes falciformes (MADIGAN et AL., 2006; VEKILOV, 2007). 
Aparentemente, existe um estado de inflamação crônica nos pacientes com AF (ADAMS, 2007), com componente de vasculopatia crônica resultante de episódios recorrentes de isquemia / hipóxia e reoxigenação, além de muitos marcadores inflamatórios estarem aumentados durante a vaso-oclusão (OPKALA, 2004; HEBBEL et al., 2004). A vaso-oclusão é um processo muito complexo, regido por vários fatores, incluindo a interação entre várias moléculas de adesão e receptores nas células vermelhas, células brancas do sangue, plaquetas e células endoteliais e proteínas plasmáticas (OPKALA, 2004; HEBBEL et al., 2004; FRENETTE, 2004).

Além das mudanças óbvias no formato das hemacias, que resulta da formação de polímeros de hemoglobina intracelular, os polímeros pode ter um impacto direto sobre a membrana plasmática da hemácia, levando a exposição extracelulares dos epítopos de proteínas e glicolipídios que são normalmente encontrados no interior da célula (Figura 1) podendo explicar a maior aderência das hemácias falciformes ao endotélio vascular (FRENETTE et al., 2007). A aderência ao endotélio é mediada por vários receptores da superfície eritrocitária, incluindo as proteínas BCAM/Lu (CD239), CD47, CD147, ICAM-4 e fosfatidilserina, que, em células normais, encontra-se restrita a superfície interna da membrana bilipídica. Alem das hemácias maduras, os reticulócitos, em número aumentado na DF, expressam uma quantidade maior dos antígenos CD36 e VLA-4, que podem também elevar significativamente a adesão ao endotélio (MADIGAN et al., 2006; CHIANG et al., 2005; ZEN et al., 2004). 


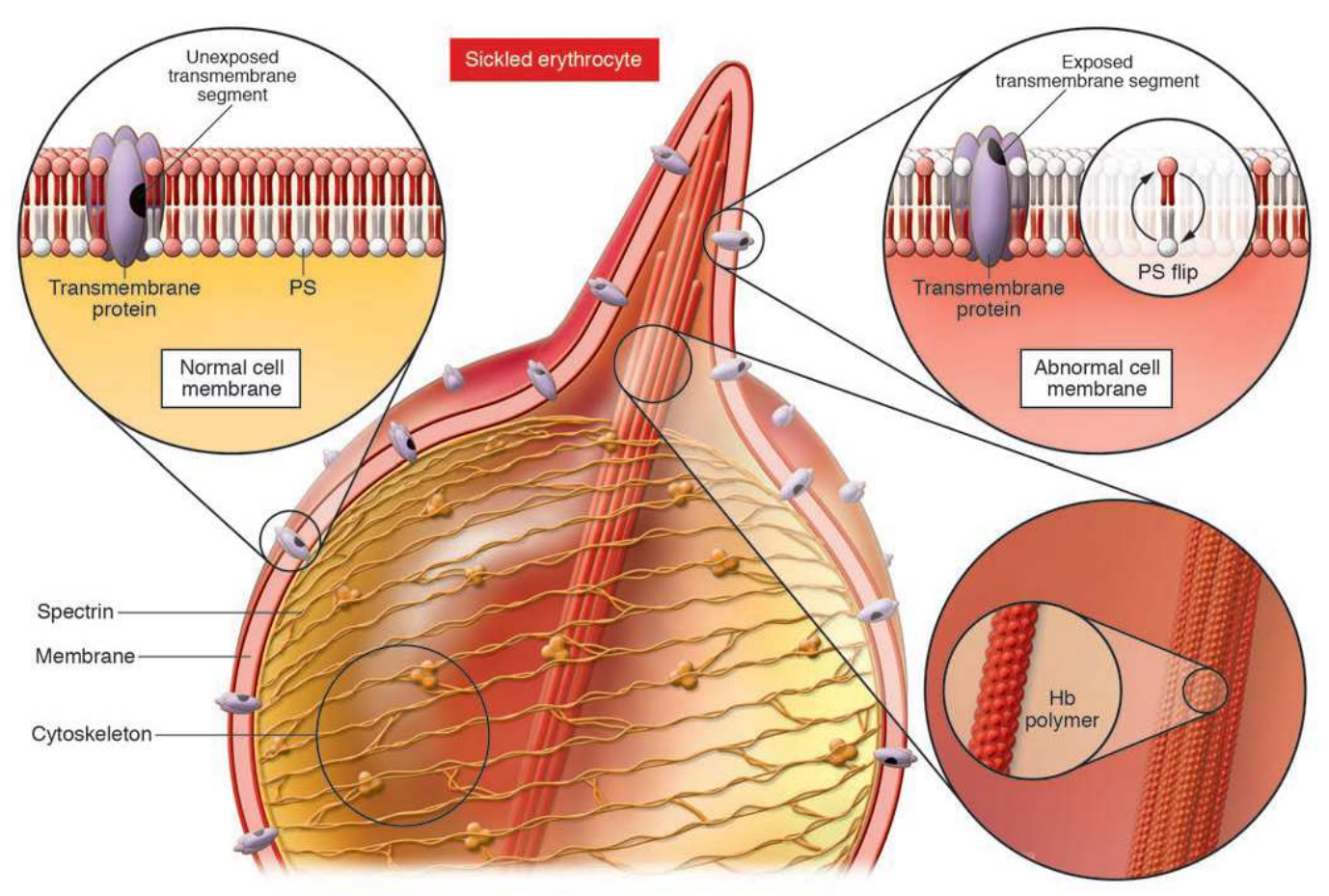

Figura 1. Alteração da membrana de hemácias por polímeros de hemoglobina falciforme. Desoxigenação da hemoglobina $S$ induz uma mudança de conformação em que 0 cadeia $b$ mutante se liga a um sitio complementar hidrofóbico resultante de uma substituição por valina, levando à formação de um polímero de hemoglobina (Hb polímero; inferior direito). Os polímeros de hemoglobina rompem o citoesqueleto da hemácia formando saliências, dando origem à característica aparência de foice. Interrupção da ligação da membrana com os resultados de proteína do citoesqueleto na exposição de transmembrana epítopos de proteínas e lipídios intercâmbios, nomeadamente de fosfatidilserina (PS), entre o interior e o exterior da célula (superior direito). Exposição de glicolipídeos carregadas negativamente contribui para o estado pró-inflamatório e pró-trombótico da anemia falciforme. Fonte: FRENETTE et al., 2007.

Na última década um conjunto significativo da literatura se acumulou, sugerindo que células circulantes do sangue estão intrinsecamente ativadas nos indivíduos falciformes, levando a uma aderencia aumentada ao endotélio; incluindo reticulócitos (BRITTAIN et al., 2008), neutrófilos (CANALLI et al., 2008; CHANG et al., 2008), monócitos (HEBBEL et al., 1985;BRITTAIN et al., 2008; BELCHER et al., 2000), e plaquetas (VILLAGRA et al., 2007; INWALD et al., 2000; LEE et al., 2006).

A inflamação, a adesão leucocitária ao endotélio vascular, a ativação de células endoteliais e a subsequente injúria endotelial, ao que tudo indica, 
exercem um papel central na patogênese da vaso-oclusão observada na AF (SONATI et al., 2008; CHIAN \& FRENETTE, 2005; OKPALA, 2006; FRENETTE et al., 2004) (Figura 2).

As interações entre células sanguineas e o endotelio envolvem proteínas de adesão endoteliais como VCAM-1 (VCAM-1), ICAM-1 (ICAM-1), E-selectina e P-selectina e uma longa lista de proteínas do plasma, que servem como intermediários na adesão, tais como fibrinogênio, fator de von Willebrand, trombospondina, e muitos outros (KATO et al., 2009). De fato, em camundongos modelos para a anemia falciforme $(\mathrm{Hb} \mathrm{S})$, a deficiencia de P e Eselectinas, moléculas de adesão chaves no rolamento e adesão de leucócitos, previne a redução do fluxo sanguíneo e diminui a incidência de morte nestes animais (TURHAN et al., 2002; FRENETTE et al., 1996).

Durante a infecção e inflamação, neutrófilos e células mononucleares ativadas são importantes produtoras de citocinas (HOFSTRA et al., 1996; LUM et al., 2004) que participam em vários processos que contribuem para a patogênese vaso-oclusivas na $A F$, incluindo ativação endotelial vascular, a indução de adesão de hemácias e leucócitos ao endotélio vascular, ativação plaquetária, produção de endotelina-1, e desregulação da apoptose endotelial (MAKIS et al., 2000).

A ativação dos monócitos, e a consequente secreção de citocinas próinflamatórias (IL-1 e TNF- $\alpha$ ), leva os leucócitos, em número constantemente elevado, a aderirem ao endotélio inflamado e a interagirem com as hemácias falcizadas (ASSIS et al., 2005; CANALLI et al., 2005; CONRAN et al., 2007). 
Apesar da inflamação crônica associada à AF ser usualmente consiredada decorrência dos episódios de vaso oclusão, Perelman e colaboradores propuseram que a produção aumentada de eritroblastos, como resultado de hemólise crônica, leva a níveis aumentados do fator de crescimento placentário (PIGF), que, por sua vez, levaria à ativação de monócitos e do endotélio, contribuindo para a vaso-oclusão (PERELMAN et al., 2003).

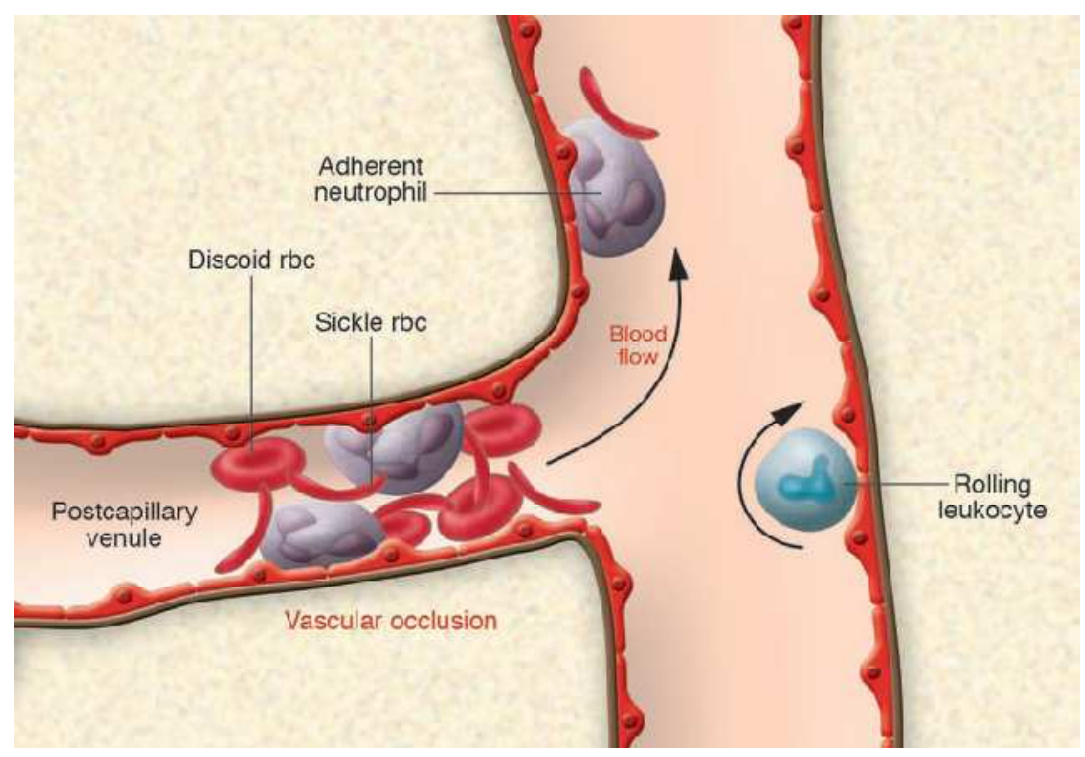

Figura 2. Oclusão Vascular na A.F. A oclusão vascular na AF é mediada por múltiplos elementos celulares, incluindo eritrócitos falcizados, células endoteliais, leucócitos aderentes e plaquetas, cada etapa pode representar um alvo útil para intervenção terapêutica. Fonte: FRENETTE et al, 2007.

Os diferentes processos biológicos envolvidos na fisiopatologia da AF sofrem a influência de múltiplos fatores envolvidos, direta ou indiretamente, nestes processos e variações genéticas entre os indivíduos, contribuem para a incidencia de diferentes manifestações clínicas comuns à AF. Neste sentido, investigações genômicas nesta área podem fornecem lições instrutivas sobre o 
potencial envolvimento de genes modificadores dos fenótipos associados à anemia falciforme (KATO et al., 2009).

\subsection{Manifestações Clínicas}

As complicações da AF são muitas, e algumas destas variam consideravelmente em freqüência e gravidade (BALLAS et al., 2009; CHUI \& DOVER, 2001; STEINBERG \& ADEWOYER, 2006) (Figura 3). Estas incluem anemia hemolítica crônica de intensidade moderada ou grave, episódios dolorosos e intermitentes de vaso-oclusão, risco permanente de infecções como resultado de auto-infarto esplênico, complicações hepáticas e biliares, complicações cardíacas que estão presentes na maioria dos pacientes. Outras manifestações clínicas tem incidência mais variável entre os pacientes (objeto de interesse no presente estudo) e incluem a síndrome torácica aguda (STA), acidentes vasculares cerebrais (AVC), priapismo, alterações ósseas (MADIGAN et al., 2006; DI NUZZO et al., 2004; LIMA et al., 2006; SEIDMAN et al., 2007; TRAINA et al., 2007) e hipertensão pulmonar, que tem sido também reconhecida como uma seria complicação, particularmente em adultos (CASTRO et al., 2003; ATAGA et al., 2004; MACHADO et al., 2005; MORRIS et al., 2005; KATO et al 2007; BARNETT et al., 2008).

\subsubsection{Sindrome Torácica Aguda (STA)}

As doenças pulmonares são as principais responsáveis pelas mortes na anemia falciforme (VENDRAMINI et al., 2004). A hiperresponsividade das vias aéreas foi descritas em pacientes com anemia falciforme, sugerindo que a inflamação das vias aéreas pode contribuir para as complicações pulmonares da doença. Indivíduos com transtornos falciformes tem uma fisiopatologia 
singular que coloca a microvasculatura do pulmão especialmente em risco (SANTOLI et al., 1998; KOUMBOURLIS et al., 2001; STYLES et al., 1996; LEONG et al., 1996).

A síndrome torácica aguda (STA) é uma complicação vaso-oclusiva relativamente comum da doença falciforme (VICHINSKY et al., 2000). A incidência é maior na crianças de 2 a 4 anos de idade, diminuindo gradualmente com a idade, mas, continuando a ser comum em adultos (BALLAS et al., 2009). A STA é segunda razão mais comum de internação, após episódios de dores vaso-oclusivas (PLATT et al., 1994), afetando cerca de $50 \%$ pacientes com anemia falciforme, pelo menos uma vez na sua vida, podendo levar a uma morte prematura dos indivíduos nesta população (PLATT et al., 1994; CASTRO et al., 1994).

A etiologia complexa e multifatorial da STA, incluindo agentes infecciosos (bacteriana, viral, micoplasma, etc) e não infecciosos (embolia gordurosa), com diferentes causas predominantes em crianças e adultos, dificultam o estudo desta manifestação (STEINBERG, 2009). Ainda, a patogênese não é completamente compreendida, dificultando assim, predizer qual paciente está sob maior risco de desenvolver STA ou diagnósticar precocemente esta grave complicação, dificultando seu tratamento adequado.

A síndrome torácica aguda é definida com a observação de um novo infiltrado pulmonar (em raio $X$ do tórax), presença de dor torácica, febre maior que $38.5^{\circ} \mathrm{C}$, taquipnéia, sibilância, ou tosse. $\mathrm{O}$ inf iltrado deve envolver pelo menos um segmento pulmonar completo para o episódio ser ser considerado STA (GILLL et al. 1995). É impossível distinguir clinicamente entre a STA e a 
pneumonia, uma vez que a radiografia de tórax e os resultados laboratoriais se sobrepõe, e o tratamento disponível atualmente é apenas de suporte (REDDING-LALLINGER et al., 2006).

\subsubsection{Hipertensão Pulmonar (H.P)}

A hipertensão pulmonar (H.P) tem sido reconhecida como cada vez mais comum e levando a complicações mortais em doentes falciformes, (GLADWIN et al., 2004; ATAGA et al., 2006; DE CASTRO et al., 2008) e outras anemias hemolíticas (BARNETT et al., 2008). Aproximadamente $40 \%$ dos adultos com anemia falciforme pode ser identificada como tendo H.P e proporções semelhantes são vistas em paciente pediátricos e adolescentes.

A hipertensão pulmonar é uma elevação de pressão na vasculatura pulmonar. A hipertensão arterial pulmonar está presente quando a pressão arterial pulmonar (PAP) é $\geq 25 \mathrm{mmHg}$, com uma pressão atrial esquerda normal. Normalmente, ela é clinicamente diagnosticada pela ultra-sonografia, utilizando o medição da regurgitação tricúspide (JRT) que geralmente está presente na hipertensão pulmonar. Pacientes com um JRT de pelo menos 2,5 $\mathrm{m} / \mathrm{s}$ são considerados como tendo H.P, o que corresponde a uma pressão arterial pulmonar de $30 \mathrm{mmHg}$. Estudos prospectivos em adultos com anemia falciforme têm mostrado que uma PAP $\geq 30$ esta associada a morbidade e mortalidade significativas (GLADWIN et al., 2004; DE CASTRO et al., 2006).

Hipertensão pulmonar tem emergido como um importante fator de risco de morte prematura em pacientes com AF e estudos para identificação de suas bases genética foram iniciados recentemente (GLADWIN et al., 2004). 


\subsubsection{Acidente Vascular Cerebral (AVC)}

Uma das complicações mais graves da doença falciforme é o acidente vascular cerebral isquêmico (AVCi) (OHENE-FREMPONG et al., 1998). Os efeitos dos transtornos falciformes no cérebro variam de acordo com idade, podendo ser agudos ou crônicos, e clinicamente evidentes ou sutis (silenciosos), podendo resultar numa significativa morbidade e até mesmo mortalidade (ADAMS et al., 1998). Pacientes com AF tem um risco global de AVCi de $3,75 \%$ ao longo da sua vida. Em geral, crianças de 2 a 5 anos de idade têm maior incidência de AVCi. O AVC hemorrágico tem a maior incidência na faixa etária de 20 a 29 anos (OHENE-FREMPONG et al., 1998). Os infartos silenciosos ocorrem em cerca de $22 \%$ das crianças com DF (MILLER et al., 2001), estando presente em crianças com menos de 4 anos de idade, com o aumento da prevalência até 14 anos de idade (BUCHANAN et al., 2004). O risco de AVC é evidentemente aumentado em 14 vezes para crianças com histórico de infarto silencioso prévio (PAVLAKIS et al., 1988).

A angiografia por ressonância magnética (MRA) é rotineiramente utilizada para documentar a estenose ou obstrução do fluxo em grandes vasos intracranianos, e correlaciona-se bem com a angiografia convencional. A ultrasonografia com Doppler transcraniano (DTC) é usada para identificar pacientes com anemia falciforme com risco aumentado para acidente vascular cerebral (ADAMS et al., 1998).

Um TCD anormal, é definido como a velocidade $>200 \mathrm{~cm} / \mathrm{s}$ na artéria cerebral média está associada com aumento do risco de derrame (REDDINGLALLINGER et al., 2006; BERNAUDIN et al., 2008). 
AVC tem sido o objeto do maior número de estudos de associação genética pois existe uma predisposição familiar na anemia falciforme, sugerindo uma possível modulação genética deste fenótipo (DRISCOLL et al., 2004).

\subsubsection{Priapismo}

O priapismo é definido como uma ereção dolorosa prolongada do pênis, sem o desejo sexual (REDDING-LALLINGER et al., 2006), sendo uma condição perigosa e de atenção urgente, por causa de sua principal complicação, a fibrose peniana (WEN et al., 2010). Sem interferência terapêutica em episódios prolongados por mais de 6 horas, o priapismo acabará levando à disfunção erétil (BURNETT, 2006).

Aproximadamente $30 \%-45 \%$ dos pacientes com anemia falciforme apresentam pelo menos um episódio de priapismo durante sua vida (MONTADAKIS et al., 1999; FOWLER et al., 1991).

Os tratamentos raramente restauram a função erétil normal e abordagens preventivas para limitar a tendência à ereção anormal, não existem; resultado da má compreensão da fisiopatologia do priapismo e da fibrose peniana. Este situação evidencia a necessidade de pesquisa básica para compreender os mecanismos moleculares da doença, de forma a desenvolver tratamento ou a prevenção do priapismo e da fibrose peniana (WEN et al., 2010).

\subsubsection{Alterações Ósseas}

Vários estudos têm mostrado uma redução global da densidade mineral nos ossos, atribuída à hiperplasia da medula óssea, em pacientes com doença 
falciforme (BRINKER et al, 1998; SOLIMAN et al 1998; VANDER JAGT et al, 2002; NELSON et al, 2003). Os mecanismos celulares e moleculares subjacentes, no entanto, não estão claros (HIRSCHHORN et al., 1979; MAC DERMOT et al., 1991).

A necrose avascular é a complicação ortopédica mais comum na DF e ocorre em até $50 \%$ de todos os pacientes (VICHINSKY et al., 1999; ADEKILE et al., 2001). Também conhecido como necrose asséptica ou osteonecrose, ocorre quando o suprimento de sangue para uma área do osso é comprometida, o que leva ao infarto e necrose celular. Estes infartos são geralmente visto nas articulações supridas por artérias finais. É presumivelmente causado pela vaso-oclusão de vasos sanguíneos que alimentam essas áreas vulneráveis.

A doença avançada pode ser facilmente diagnosticada através de radiografias simples, já o início é melhor diagnosticado por ressonância magnética e não é detectado por radiografia simples (MILNER et al., 1991; GUPTA \& ADEKILE, 2004). O local mais comum de osteonecrose é a cabeça do fêmur seguido da cabeça do úmero, joelho, e as pequenas articulações das mãos e pés (LONERGAN t al., 2001; JEAN BAPTISTE et al). Usando ressonância magnética, Ware et al., 1991 encontraram osteonecrose da epífise de quase $41 \%$ dos adultos com doença falciforme. Adekile et al., 2001, encontrou uma prevalência ligeiramente mais baixa em crianças (27\%). Uma taxa de $3 \%$ de prevalência tem sido relatada em menores de 15 anos de idade. A taxa de prevalência de necrose avascular da cabeça femoral aumenta com idade (GUPTA \& ADEKILE, 2004). 


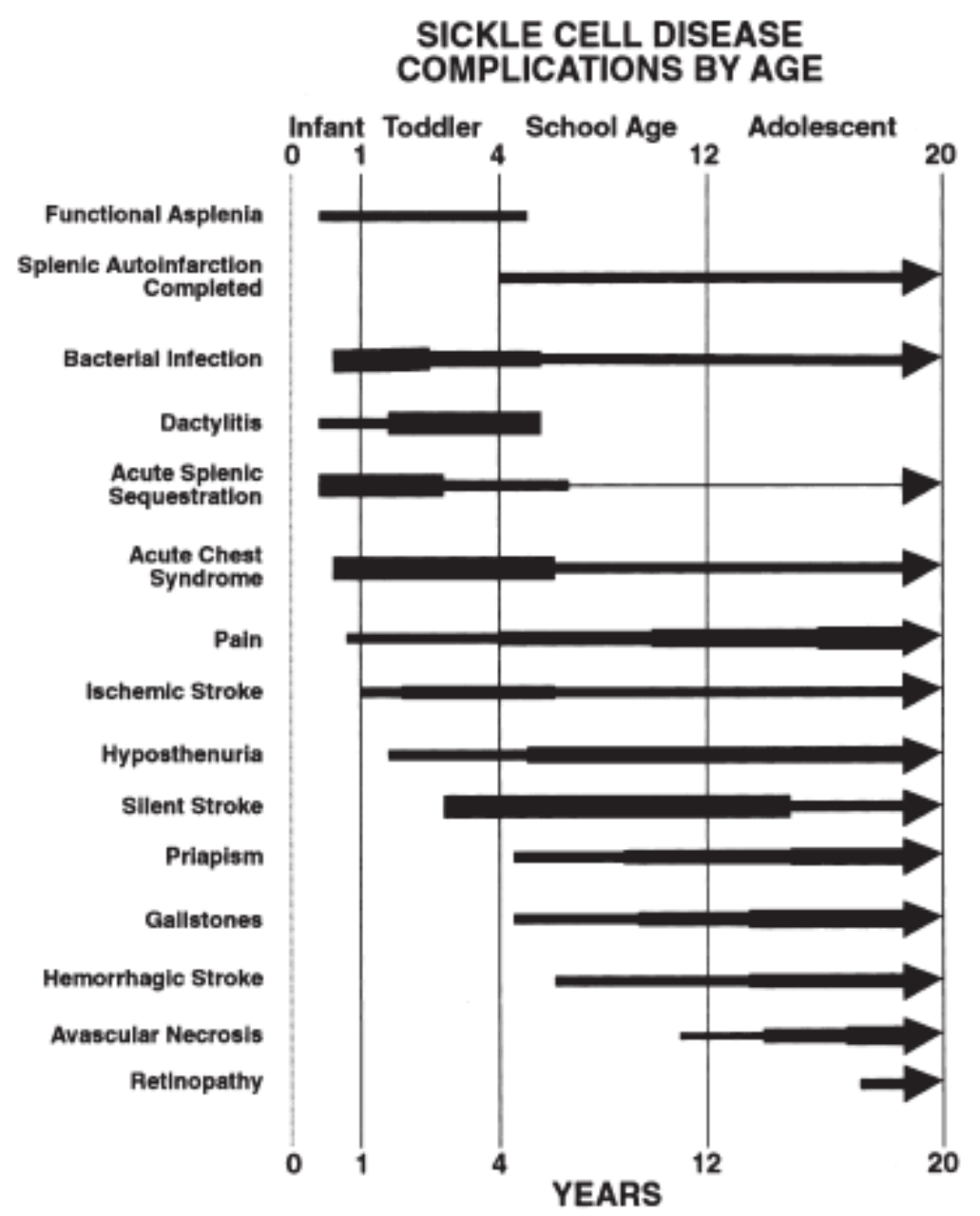

Figura 3. Complicações da doença falciforme por idade. Fonte: REDDINGLALLINGER et al., 2006. 


\subsection{Tratamento Hidroxiuréia}

O principal medicamento utilizado no tratamento da $\mathrm{AF}$, visando uma redução nas manifestações clínicas associadas, é a Hidroxiuréia (HU), também conhecida como Hidroxicarbamida, um inibidor da Ribonucleotideo Redutase que tem efeitos citotóxicos mielossupressores. Este medicamento é o único indutor de $\mathrm{Hb} F$ aprovada pela Food and Drug Administration EUA (FDA) em 1998, para o tratamento de adultos com AF, mas atualmente não tem uma indicação aprovada pelo FDA para crianças (STROUSE et al., 2008).

Um grande estudo feito pelo Multicenter Study of Hydroxyurea (MSH) mostrou um diminuição marcante na freqüência de crises dolorosas e síndrome torácica aguda e redução no requerimento de transfusões e hospitalizações em adultos com anemia falciforme de moderada a severa (CHARACHE et al., 1995) reduzindo a mortalidade em cerca de 40\% (STEINBERG et a., 2003; DAVIES et al., 2003). Depois de 9 anos, paciente com AF tratados com HU mostrou-se um aumento da sobrevivência. Porém, cerca de 30\% dos pacientes são não-respondedores (STEINBERG et al., 2003).

Os efeitos benéficos da HU seriam devidos, em parte, à produção de hemácias com níveis elevados de hemoglobina fetal $(\mathrm{Hb} F)$, resultante do recrutamento precoce de células progenitoras durante a regeneração eritróide, e a consequente interferencia na polimerização da Hb S (DOVER et al, 1986; STEINBERG, 2009). No entanto, seu exato mecanismo de ação ainda não esta completamente elucidado (SONATI et al., 2008).

O fato de que os benefícios clínicos da HU ocorram antes do aumento da $\mathrm{HbF}$ (BRIDGES et al., 1996), sugerem que essa droga pode também atuar 
através de outra mecanismos (ROTTER et al., 2005). De fato, a redução no número de leucócitos circulantes também esta associada aos efeitos benéficos da HU (CHARACHE et al., 1995).

Outros mecanismos de ação da HU adicionais, envolveriam a redução na adesão das hemácias falcifadas às células endoteliais e à laminina (BRIDGES et al., 1996; ADRAGNA et al., 1994; HILLERY et al., 2000), decorrente da redução na expressão ou interferência em moléculas envolvidas na adesão celular, como os receptores de adesão a4ß1 e CD36 em reticulócitos falciformes (STYLES et al., 1997).

Tendo em vista que o efeito benéfico da $\mathrm{HU}$ pode resultar de sua ação sobre diferentes células sanguineas; considerando que pacientes falciformes apresentam uma elevação nos números de monócitos, células com papel importânte na fisiopatologia da AF (Wun et al.); em colaboração conjunta entre os Profs. Drs. Marco A. Zago, Dimas T. Covas e Jaques Elion (Paris, França), o efeito do tratamento com hidroxiuréia sobre o perfil transcricional de monócitos CD14+ de pacientes falciformes, foi avaliado (projeto de PhD corrente da $\mathrm{Dr}$. Ana Cristina S. Pinto). As análises preliminares (realizadas pelo Dr. Panepucci em visita à França, FAPESP $N^{0}$ 2008/53136-9) indicaram uma alteração mínima no perfil de expressão destes dois grupos, no entanto, alguns poucos genes com relevância na fisiopatologia da anemia falciforme puderam ser identificados. Entre eles, o gene da enzima adenosina deaminase (ADA), responsável pela redução dos níveis de adenosina por sua conversão em inosina, teve os níveis de seus transcritos significativamente mais altos nos monócitos de pacientes tratados com HU. 
Interessantemente, ao mesmo tempo que estes resultados foram encontrados, um estudo revelou que os episódios freqüentes de priapismo em camundongos modelos de anemia falciforme, resultavam de um aumento dos níveis de adenosina no corpo cavernoso destes animais (comparado a animais controles). Curiosamente, a descoberta foi resultado da observação de que camundongos deficientes para a enzima ADA (ADA-/-), mantidos vivos por suplementação com ADA peguilada, apresentavam episódios de priapismo próximo à data das injeções de ADA, quando os níveis de adenosina se acumulavam nos animais (Mi et al, 2008).

Estes resultados, levaram à hipótese de que o aumento da expressão da enzima ADA nos monócitos de pacientes tratados com HU, e uma conseqüente redução nos níveis de adenosina, poderiam constituir um mecanismo de ação complementar da HU sobre os processos fisiopatológicos alterados nos pacientes com anemia falciforme.

Com estes resultados em vista, decidimos investigar os mecanismos moleculares envolvidos na sinalização mediada por adenosina, bem como no controle de seus níveis, e sua associação com processos fisiopatológicos potencialmente associados às diferentes manifestações clínicas observadas na anemia falciforme. 


\subsection{Fisiopatologia da Adenosina}

A adenosina é um nucleosídeo de purina que é produzido por muitos tipos celulares durante a atividade metabólica normal (OLAH \& STILES, 1995; PALMER \& STILES, 1995; RALEVIC \& BURNSTOCK, 1998). Nestas condições, a adenosina esta constitutivamente presente em baixos níveis no meio extracelular, no entanto, seus níveis são aumentados em condições de estresse metabólico (SITKOVSKY and LUKASHEV, 2005) e em situações de estresse tecidual, tais como a isquemia, onde a estimulação de diferentes receptores de adenosina $(A 1, A 2 A, A 2 B$, e $A 3)$ induz, subsequentemente, uma vasta gama de efeitos, atuando de forma a proteger os tecidos (FREDHOLM et al., 2001; LINDEN, 2005). Uma vez liberada, a adenosina atua como um fator parácrino com efeitos locais em uma variedade de tecidos (BELARDINELLI et al., 1989; FREDHOLM \& DUNWIDDIE, 1988; HUANG et al., 1997;

SITARAMAN et al., 2001; VAN BELLE et al., 1987). A adenosina desempenha funções importantes de sinalização na regulação da homeostase em vários sistemas fisiológicos, incluindo o sistema nervoso simpático (FREDHOLM \& DUNWIDDIE, 1988), o sistema renal (CHURCHIL, 1982), o sistema imunológico (KOSHIBA et al., 1997; HUANG et al., 1997) e o sistema cardiovascular (BELARDINELLI et al., 1989); atuando na inibição da agregação plaquetária, inibição da inflamação e na modulação da proliferação e morte de células musculares lisas e células endoteliais(RONGEN et al.,1997).

A geração da adenosina é dependente do equilíbrio entre as atividades de enzimas que catalisam sua síntese e degradação (ROMAN et al., 2006). Durante a inflamação, a produção extracelular da adenosina é mediada por 
duas enzimas: CD39 (da família ecto-nucleosídeo trifosfato difosfoidrolase), que converte ATP e ADP em 5'-AMP; e CD73 (ecto-5'-nucleotidase), que hidrolisa o 5'-AMP para formar adenosina (BEHDAD et al., 2009;ELTZSCHIG et al., 2003;RESTA et al., 1998). A degradação da adenosina no citosol ocorre pela adenosina desaminase ( $A D A)$, que a converte em inosina; esta é então convertida para ácido úrico ou é refosforilada pela adenosina quinase (ZIMMERMANN et al., 2002; FRANCO et al., 1998). Extracelularmente, a enzima ADA é ancorada pela proteina CD26 (dipeptidil-peptidase IV), levando a uma redução na concentração local de adenosina, nas imediações da superfície celular (KAMEOKA et al., 1993;MORIMOTO and SCHLOSSMAN, 1998;DONG et al., 1996).

Apesar do papel benéfico da adenosina em diferentes situações fisiológicas normais, níveis excessivos de adenosina são citotóxicos (CERUTI et al., 2000; ROUNDS et al., 1998) e podem levar a alterações patológicas em diferentes tecidos.

Nas duas últimas décadas, tornou-se claro que adenosina é um mediador pró-inflamatório envolvidos na patogênese da asma e outras doenças pulmonares inflamatórias. Esta noção é baseada na observação de que a adenosina induz a hiper-reatividade e broncoconstrição em modelos animais e em pacientes com doenças inflamatórias das vias aéreas, como asma crônica e doença pulmonar obstrutiva crônica (DPOC), e no fato de que receptores de adenosina estão presentes em vários tipos celulares envolvidos na inflamação das vias aéreas (SPRICUZZA et al., 2003; ROMAN et al., 2006). Além disso, níveis aumentados de adenosina tecidual estão associados com inflamação (BLACKBURN et al., 2000; CHUNN et al., 2001), estando também associados 
com a remodelação tecidual, exemplificada pelo alargamento alveolar, espessamento da parede das vias aéreas, metaplasia de muco e fibrose tecidual (BLACKBURN et al., 2003).

Como já mencionado, a sinalização da adenosina tem papel descrito na regulação da ereção peniana (CHIANG et al., 1994; YONEZAWA et al., 2002. NOTO et al., 2001) e estudos recentes fornecem evidências diretas de que a adenosina em excesso contribui para o priapismo em camundongos deficientes de ADA e camundongos transgênicos falciformes (MI et al., 2008). Diversos achados sugerem que a adenosina pode contribuir para a ereção peniana , através da ativação de receptores de adenosina (TOSTES et al., 2007; FARIA et al., 2006; DAl et al., 2009).

Defeitos esqueléticos também estão associados a alterações nos níveis da adenosina, sendo uma característica comum em pacientes com Imunodeficiência Combinada Grave (Severe combined immunodeficiency SCID), causada pela deficiência da enzima adenosina deaminase (RATECH et al., 1998; CHAKRAVARTI et al., 1991).

Várias outras situações patologicas tem sido associadas a alterações no equilíbrio entre a produção e a degradação da adenosina, incluindo ateroscleroses (TSAl et al., 1994), derrames (HANKEY \& EIKELBOOM, 2001) e trombose (DUNHAM et al., 1998). Ainda, elevado níveis de ATP foram encontrados no fluido sinovial de pacientes com osteoartrite (OA) e artrite reumatóide (RA) (YAMAKAWAH et al., 1998; JOHNSON et al., 1999).

Além disso, a estimulação dos receptores de adenosina tem se mostrado capaz de inibir o desenvolvimento e a progressão de lesões 
ateroscleróticas em vários modelos animais (McPHERSON et al, 2001;. ZERNECKE et al, 2006).

Apesar de ser uma doença mendeliana típica (com envolvimento de um único gene), pacientes com AF apresentam manifetações clínicas diversas, sugerindo que a variação em outros genes (associada a influências do ambiente) contribuiriam na modulação do fenótipo da anemia falciforme (STEINBERG, 2009).

Considerando o papel da adenosina e seus receptores sobre processo fisiopatológicos potencialmente ligados às manifestações clínicas observadas na doença falciforme, consideramos que polimorfismo em presentes nos genes da adenosina deaminase e seus receptores poderiam contribuir para a variabilidade observada entre os pacientes falciformes.

Adicionalmente, dada a indução da expressão de ADA, observada em monocitos de pacientes tratados pela $\mathrm{HU}$, consideramos que outros componentes ligados à síntese ou degradação da adenosina, poderiam estar sendo modulados pela $\mathrm{HU}$. 
2. OBJETIVOS

Página | 39 


\subsection{Objetivos gerais}

O presente trabalho teve como objetivo estudar a modulação de componentes envolvidos na síntese e degradação da adenosina, pela hidroxiuréia em pacientes falciformes, além de verificar a possível influência de polimorfismos presentes nos genes da enzima adenosina deaminase (ADA) e de receptores de adenosina sobre a diversidade das fisiopatologias destes pacientes.

\subsection{Objetivos Específicos}

Avaliar a associação de polimorfismos nos receptores de adenosina ADORA 1 e ADORA 3 e no gene da adenosina deaminase, já descritos na literatura, com as diferentes manifestações clínicas comuns a doença falciforme.

Seqüenciamento e identificação de polimorfismos na região codante do gene de receptores de adenosina $\mathrm{A} 2 \mathrm{~B}$ e avaliar sua possível associação com as diferentes manifestações clínicas da doença falciforme.

Avaliar o efeito da hidroxiuréia na modulação da expressão de adenosina deaminase (mRNA) em monócitos de pacientes falciformes, por PCR em tempo real.

Avaliar o efeito da hidroxiuréia na modulação da expressão de marcadores envolvidos na síntese e degradação da adenosina em linfócitos e monócitos de pacientes falciformes, por citometria de fluxo. 
3. MATERIAIS E MÉTODOS 


\subsection{Pacientes}

As amostras foram coletadas de 230 pacientes com Doença Falciforme (SS e $S \beta$ ) do Hemocentro de Ribeirão Preto, atendidos pela equipe de enfermeiros do ambulatório deste estabelecimento (Hemocentro de Ribeirão Preto - Centro regional de Hemoterapia do HCFMRP-USP), seguindo protocolo aprovado pelo Comitê de Ética e Pesquisa (CEP) do Hospital Universitário da Faculdade de Medicina de Ribeirão Preto (processo HCRP n¹668/2009).

\section{2. $\quad$ Coleta de Sangue Periférico}

Para análise molecular foram coletados $5 \mathrm{ml}$ de sangue periférico de cada paciente em tubo estéril tipo Vacutainner contendo anticoagulante ácido etilenodiaminotetracético (EDTA). O material foi obtido após esclarecimento ao paciente ou familiares sobre a pesquisa e assinatura do termo de consentimento livre-esclarecido (Anexo). Após a coleta, as amostras foram encaminhadas ao laboratório de Biologia Molecular do Hemocentro para prosseguir com a extração de DNA.

\subsection{Extração, Quantificação e Armazenamento das Amostras}

\section{de DNA}

O DNA genômico foi extraído a partir de $5 \mathrm{ml}$ de sangue, coletado em tubos com anti-coagulante EDTA utilizando o kit da QIAGEN (FlexiGene DNA kit (250)). Primeiramente foi feita a centrifugação a 2000 RPM por 10 minutos para separação do plasma, que foi armazenado a $-80^{\circ} \mathrm{C}$ no banco de plasma 
de Doença falciforme do Hemocentro. $\mathrm{O}$ anel de células mononucleares (Buffy Coat) formado foi recolhido e transferido para um tubo de microcentrífuga de 1,5ml contendo $750 \mu \mathrm{l}$ de uma solução de lise de glóbulos vermelhos (FG 1). Após homogeneização da mistura por inversão e centrifugação a 10.000 RPM por 3 minutos, o sobrenadante foi desprezado mantendo o tubo invertido por 2 minutos. Em seguida, $300 \mu \mathrm{l}$ de tampão de desnaturação (FG 2), contendo $3 \mu \mathrm{l}$ de protease, foi adicionado ao tubo e o pellet foi então imediatamente homogeneizado com auxílio de um vortex. Após um breve spin o tubo foi incubado em um banho maria a $65^{\circ} \mathrm{C}$ por 10 minutos. A pós a incubação, $300 \mu \mathrm{l}$ de isopropanol absoluto (Merk, Alemanha) foram adicionamos ao tubo e misturados por inversão até precipitação do DNA; em seguida o tubo foi centrifugado a 10.000 RPM por 3 minutos. Após descarte do sobrenadante, o pellet de DNA foi lavado com a adição de etanol 75\%, agitação em vortex por 5 segundos, centrifugação, descarte do sobrenadante e secagem do tubo (mantido invertido por 5 minutos). Finalmente, o pellet de DNA foi ressuspendido em $200 \mu$ l de um tampão de solubilização (FG 3) com auxílio de um vortex e após incubação a $65^{\circ} \mathrm{C}$ por 10 minutos.

Para se avaliar a qualidade e integridade do DNA, foi realizada a quantificação do DNA por espectrofotometria Nanoveu (GE). Desta forma procedeu-se a leitura da absorbância a $260 \mathrm{~nm}\left(\mathrm{~A}_{260}\right)$, cujo comprimento de onda é da região ultravioleta. A relação entre as leituras obtidas nos comprimentos de ondas $A_{260}$ e $A_{280}\left(A_{260}\right.$ e $\left.A_{280}\right)$, que fornece uma estimativa da pureza do ácido nucléico, e a verificação da concentração do DNA extraído, também foram avaliadas. 
A solução contendo o DNA extraído e quantificado foi distribuída em dois tubos de 1,5 mL, um com 150 ul para compor o Banco de DNA de Doença Falciforme do Hemocentro de Ribeirão Preto como estoque e a outra alíquota de 50 ul para a realização do experimento e uso contínuo. As amostras de DNA para trabalho foram padronizadas para uma concentração de $100 \mathrm{ng} / \mathrm{ul}$ e 10 ng/ul. Todas as amostras foram estocadas em freezer a $-20^{\circ} \mathrm{C}$. Os microtubos destinados ao Banco de DNA foram mantidos em freezer $-80^{\circ} \mathrm{C}$, e aquelas utilizadas rotineiramente eram conservadas no Freezer $-20^{\circ} \mathrm{C}$. Todo o processo de extração, quantificação e armazenamento foram registrados em um banco de dados montado no programa Microsoft Excel 2007.

\subsection{Revisão de Prontuários Médicos}

Com o objetivo de definir grupos de pacientes apresentando (ou não) uma dada manifestação clínica para os estudos de associação com os polimorfismos, foi feita a revisão dos prontuários médicos de cada paciente. A realização desta revisão foi realizada após orientação da médica hematologista Ana Cristina S. Pinto, sobre os termos técnicos a serem identificados nos prontuários. O relato de uma dada manifestação clínica, mesmo que em episódio único, foi considerado suficiente para incluir o paciente no grupo equivalente. Tanto pacientes com diagnóstico SS e SB foram considerados para a análise deste trabalho devido à semelhança das sintomatologias (CLASTER et al 2003; BERRY et al., 2007). As principais manifestações encontradas foram síndrome torácica aguda (STA), hipertensão pulmonar, priapismo, alterações ósseas como osteopenia e osteoporose e acidente vascular cerebral (AVC). 


\subsection{Polimorfismos Selecionados}

Foram selecionados para esse estudo 3 polimorfismos (rs1685103; rs35511654 e G22A GeneBank M13792) em 3 genes diferentes, já descritos na literatura relacionados com algumas manifestações clínicas comuns a doença falciforme como pode ser visto na tabela 1. As seqüências podem ser encontradas no banco de dados dbSNP (http://www.ncbi.nlm.nih.gov/projects/SNP/).

O SNP do gene ADORA 1 (rs1685103), está localizado na região 3'UTR, e resulta de uma substituição de transição entre as bases pirimidicas $C$ e T. No gene que ADORA 3, o SNP (rs35511654) se encontra em um íntron e é resultado de uma substituição transversal entre a base purica $G$ e a base pirimidicas T, por último o SNP G22A (Asp8Asn, ADA*2) do gene ADA é uma mutação de transição na $22^{\mathrm{a}}$ base da ORF ( ${ }^{\circ}$ códon), da base purica $\mathrm{G}$ para A, que leva à substituição do ácido aspártico (Asp) pela asparagina (Asn).

Tabela 1. Descrição dos polimorfismos selecionados para o estudo de associação com as manifestações clínicas da Anemia Falciforme.

\begin{tabular}{|c|l|}
\hline $\begin{array}{c}\text { Gene e Polimorfismo } \\
\text { (dbSNPs) }\end{array}$ & \multicolumn{1}{c|}{ Associações Relatadas na Literatura } \\
\hline $\begin{array}{c}\text { ADORA1 (rs1685103) } \\
\text { Alelos (C/T) }\end{array}$ & Asma (KIM et al., 2009) \\
\hline ADORA3 (rs35511654) & Cardiomiopatia isquêmica (TANG et al., 2007) \\
\hline Alelos (G/T) & Doença Cardiovascular (SAFRANOW et al., 2007) \\
\hline ADA*2 (G22A, Asp8Asn) & Asma Brônquica (BOTINNI et al., 2005) \\
\hline (GeneBank: M13792). &
\end{tabular}




\subsection{Desenho de Sondas para Discriminação Alélica}

As seqüências encontradas no banco de dados dbSNP, foram utilizadas para o desenho customizado de primers e sondas Taqman para PCR em tempo real (Applied Biosystem), com o objetivo de amplificar os fragmentos de interesse contendo o SNP e, ao mesmo tempo, detectar e discriminar os alelos de cada indivíduo. Informações adicionais sobre as sondas, assim como a freqüência populacional derivada do projeto HapMap (http://hapmap.ncbi.nlm.nih.gov), se encontram na tabela 2.

Para o polimorfismo $\mathrm{ADA}^{\star} 2$ do gene $\mathrm{ADA}$, retirou-se da literatura a informação da seqüência para o desenho do iniciador para a região polimórfica G22A (GenBank: M13792) (SAFRANOW et al., 2007), sendo realizada pela técnica de RFLP (Restriction Fragment Lenght Polymorphism) (Tabela 3). 


\subsection{Desenho de iniciadores para seqüenciamento}

A seqüência do gene ADORA 2B encontrada no banco de dados do NCBI (Entrez Gene), foi utilizada para desenhar os iniciadores para PCR, com o objetivo de amplificar os dois éxons de interesse que compõem a proteína traduzida. Os iniciadores foram obtidos utilizando o software Primer 3 Plus, o qual está disponível na internet (http://www.bioinformatics.nl/cgi bin/primer3plus/primer3plus. cgi). Para verificar a inexistência de dímeros formados pelos pares de iniciadores utilizamos o programa Autodimer e para checar o anelamento dentro do mesmo iniciador utilizamos o programa OligoCalc (disponível em (http://www.basic.northwestern.edu/biotools/oligocalc.html), finalmente fez-se o alinhamento da seqüência utilizando o programa BLAST (disponível em http://blast.ncbi.nlm.nih.gov/Blast.cgi), para se ter certeza da especificidade desta, evitando o anelamento em regiões inespecíficas, maximizando assim o sucesso da reação de PCR.

Foram considerados a porcentagem de GC menor que $60 \%$, a temperatura de anelamento $\left(T_{m}\right)$ dos pares de primers próximas e tamanho do amplicon gerado para o seqüenciamento dentro de 500 pb, para se obter uma seqüência de boa qualidade, sem perda de informação confiável, gerando 4 pares de iniciadores (Tabela 4). 
Tabela 4 - Iniciadores desenhados para o seqüenciamento do éxon 1 e 2 do gene ADORA 2B

\begin{tabular}{|c|c|c|c|c|}
\hline Gene & ÉXON & SEQUENCIA (5'-3') & DIRECCÃO & $\begin{array}{l}\text { TAMANHO DO } \\
\text { AMPLICON }\end{array}$ \\
\hline \multirow{8}{*}{$\begin{array}{l}\text { ADORA 2B } \\
\text { (Crom. 17) }\end{array}$} & CDS1_1 & AGC CCC GAG GCT CAG AAG & Direto & $370 \mathrm{bp}$ \\
\hline & & AGA GGC AGC CGT AGA AGT CA & Reverso & \\
\hline & CDS1_2 & AGA CGC CCA CCA ACT ACT TC & Direto & $286 \mathrm{bp}$ \\
\hline & & TGG AGA AGA CGA CCC ATT TC & Reverso & \\
\hline & CDS2_1 & TCT TGG ATT GTG GTT GCA GA & Direto & $458 \mathrm{bp}$ \\
\hline & & GCA AAA ATC CCC ACA ATC AT & Reverso & \\
\hline & CDS2_2 & GTT CTG CCC CCA CTG CTT AT & Direto & $492 \mathrm{bp}$ \\
\hline & & CAG CCG TGT CCT CTT TGT TT & Reverso & \\
\hline
\end{tabular}

\subsection{Padronização das reações de PCR}

A discriminação alélica foi feita por PCR em tempo real, no aparelho 7300 Real Time PCR System, utilizando sondas TaqMan (Applied Biosystems). O protocolo foi realizado utilizando-se 6,25 ul Master Mix, 0,3125 ul de cada sonda (40 X), 3,9375 de água milli $Q$ e $2 u$ de DNA, totalizando um volume de 12,5 ul. As reações foram montadas em placas de 96 poços e a reação seguiu o seguinte ciclo: 2 minutos a $50^{\circ} \mathrm{C}, 10$ minutos a $95^{\circ} \mathrm{C}, 40$ ciclos de $95^{\circ} \mathrm{C}$ por 15 segundos e 1 minuto a $60^{\circ} \mathrm{C}$.

A genotipagem do polimorfismo $\mathrm{ADA}^{\star} 2$ foi realizada pela técnica de RFLP (Restriction Fragment Lenght Polymorphism). Esta técnica se baseia na amplificação do fragmento polimórfico, seguida de sua digestão utilizando enzima de restrição específica para o sítio polimórfico e posterior avaliação do tamanho dos fragmentos gerados. 
Para isso, o DNA genômico a $100 \mathrm{ng} / \mathrm{ul}$, foi utilizado em reações de PCR, utilizando primers flanqueando a região polimórfica G22A (GenBank: M13792). A reação foi preparada com um volume final de $25 \mu \mathrm{l}$ contendo: $2,5 \mu \mathrm{l}$ PCR Buffer, $2 \mu \mathrm{l}$ dNTPMix, 2,5 $\mu \mathrm{l}$ de cada primer, $2,5 \mu \mathrm{l}$ de DMSO e $\mathrm{H}_{2} \mathrm{O}$ milli $\mathrm{Q}$ necessária para completar o volume final de $25 \mu$ l. O produto de PCR amplificado possui um comprimento de 397 pb. As condições de amplificação se encontram especificadas na tabela 5.

Tabela 5 - Condições de amplificação de PCR para a região polimórfica do gene ADA.

\begin{tabular}{|c|c|c|c|c|c|}
\hline Gene & Primer & Sequiência $\left(5^{\prime}-3^{\prime}\right)$ & Temp. de Anelamento & $\begin{array}{l}\text { Condições } \\
\text { para a PCR }\end{array}$ & $\begin{array}{l}\text { Número } \\
\text { de Ciclos }\end{array}$ \\
\hline \multirow{5}{*}{ ADA } & & & Desnaturação Inicial & $94 \mathrm{C}-3^{\prime}$ & \multirow{5}{*}{35} \\
\hline & & & Desnaturação & $94 \mathrm{C}-40 "$ & \\
\hline & Forward & GCCCGGCCCGTTAAGAAGAGC & Anelamento & $68 \mathrm{C}-80 "$ & \\
\hline & \multirow[t]{2}{*}{ Reverse } & GGTCAAGTCAGGGGCAGAAGCAGA & Extensão & $72 \mathrm{C}-80 "$ & \\
\hline & & & Extensão Final & $72 \mathrm{C}-8^{\prime}$ & \\
\hline
\end{tabular}

Após a realização do PCR, o produto amplificado foi confirmado por eletroforese em gel de agarose (2\%) corado com Brometo de Etídeo. Os resultados foram obtidos com fotografias do gel em luz U.V. Em seguida o produto de PCR foi submetido a uma digestão enzimática. Para isso, uma reação contendo $5 \mu$ de Buffer Taq (Biolabs, New England), 0,25 $\mu$ l da enzima de restrição Taq I (Biolabs, New England), $5 \mu$ do produto de PCR e $\mathrm{H}_{2} \mathrm{O}$ milli Q necessária para completar o volume final de $50 \mu \mathrm{l}$ foi incubada a $65{ }^{\circ} \mathrm{C}$ overnight. Finalmente, os produtos digeridos foram separados por eletroforese 
em gel de agarose a $2 \%$, corado com Brometo de Etídeo e visualizado em luz ultravioleta. Um marcador de peso molecular foi utilizado para identificar os fragmentos gerados.

\subsection{Seqüenciamento}

O seqüenciamento foi realizado em um sequenciador MegaBACE 1000 (GE Helthcare, Buckinghamshire, Reino Unido) pertencente ao Laboratório de Genética Molecular e Bioinformática, Sala de Seqüenciamento Automático de DNA, sediado no Hemocentro de Ribeirão Preto.

Inicialmente, os dois éxons que compõe o gene ADORA 2B foram amplificados utilizando 1 ul de DNA a 100 ng/ul, através da reação com volume final de 25 ul contendo, 2,5 ul de Buffer, 2 ul de dNTP, 1 ul de cada primer forward e reverse (10 uM), 0.2 ul de Taq DNA Polimerase (1U), 2 ul de DMSO e $\mathrm{H}_{2} \mathrm{O}$ milli $\mathrm{Q}$ necessária para completar o volume final de $25 \mu \mathrm{l}$, nas seguintes condições de termociclagem mostrado na tabela 6.

Tabela 6 - Condições de amplificação de PCR para o seqüenciamento do gene ADORA $2 B$.

\begin{tabular}{|c|c|c|}
\hline Temp. de Anelamento & $\begin{array}{l}\text { Condições } \\
\text { para a PCR }\end{array}$ & $\begin{array}{l}\text { Número } \\
\text { de Ciclos }\end{array}$ \\
\hline Desnaturação Inicial & $94 \mathrm{C}-5^{\prime}$ & \\
\hline Desnaturação & $\left.94 \mathrm{C}-1^{\prime} \quad\right)$ & \\
\hline Anelamento & $55 \mathrm{C}-1^{\prime}$ & 35 \\
\hline Extensão & $72 \mathrm{C}-1^{\prime}$ & \\
\hline Extensão Final & $72 \mathrm{C}-7^{\prime}$ & \\
\hline
\end{tabular}


O sucesso da amplificação foi verificado por eletroforese em gel de agarose na concentração de $2 \%$, corado com Brometo de Etídeo. Os resultados foram obtidos com fotografias do gel em luz U.V. O produto de PCR foi quantificado por espectrofotometria utilizando o aparelho Nanovue (GE Helthcare) e então diluídos, se necessário, a uma concentração de 200 ng/ul para garantir uma boa reação de seqüenciamento.

Em seguida, a reação de amplificação para o seqüenciamento dos fragmentos foi realizada, utilizando-se o produto de PCR a $200 \mathrm{ng} / \mathrm{ul}$ para um volume final de 20 ul, contendo 8,2 ul de Premix ET, 1,3 ul de cada primer forward ou reverso separadamente para cada reação e $\mathrm{H}_{2} \mathrm{O}$ milli $\mathrm{Q}$ necessária para completar o volume final de $20 \mu \mathrm{l}$. A reação se deu nas condições descritas na tabela 7.

Tabela 7 - Condições de amplificação de PCR para análise dos fragmentos dos éxons do gene ADORA 2B no seqüenciador automático MegaBACE 1000 .

\begin{tabular}{|c|c|c|}
\hline $\begin{array}{l}\text { Temp. de } \\
\text { Anelamento }\end{array}$ & $\begin{array}{l}\text { Condições } \\
\text { para a PCR }\end{array}$ & $\begin{array}{l}\text { Número } \\
\text { de } \\
\text { Ciclos } \\
\end{array}$ \\
\hline Desnaturação Inicial & $95 \mathrm{C}-2^{\prime}$ & \\
\hline Desnaturação & $95 \mathrm{C}-10^{\prime}$ & 35 \\
\hline Anelamento & $51 \mathrm{C}-15^{\prime \prime}$ & \\
\hline Extensão & $60 \mathrm{C}-1^{\prime}$ & \\
\hline
\end{tabular}

A análise dos eletroferogramas foi realizada com ajuda do Grupo de Bioinformática do Hemocentro de Ribeirão Preto. O programa Phred (EWING et al., 1998; EWING \& GREEN, 1998) foi utilizado para o processamento inicial dos cromatogramas e a montagem dos contigs ou éxons foi realizada pelo programa PHRAP (GREEN., program for shotgun sequence assembly - 
http://www.phrap.org/). Finalmente, para a identificação dos SNPs em regiões de alta similaridade de alinhamento múltiplo foi utilizado o programa PolyPhred (NICKERSON et al., 1997). A partir do programa Consed (GREEN et al., 1998) foi possível visualizar a montagem dos éxons e dos SNPs, nele contidos.

\subsection{Genotipagem Por Discriminação alélica (RT-PCR)}

A genotipagem para os 2 SNPs rs35511654 e rs752659, dos respectivos genes ADORA1, ADORA 3 foi realizada por discriminação alélica realizada de forma automática pelo programa do aparelho 7300 Real Time PCR System.

\subsubsection{Por Seqüenciamento}

Para a genotipagem dos SNPs do gene ADORA 2B realizamos 0 seqüenciamento próximo da região polimórfica, utilizando os mesmos iniciadores anteriormente descritos, visando assim uma genotipagem altamente confiável.

\subsubsection{Por RFLP}

O genótipo de cada indivíduo para o polimorfismo $A D A{ }^{\star} 2$ foi determinado com base no padrão de fragmentos visualizados em gel. A enzima de restrição Taq I reconhece e cliva a seqüência no alelo $G$ gerando dois fragmentos (245 pb e 152 pb), mas não cliva a seqüência no alelo A. Assim, o indivíduo com genótipo homozigoto para 0 alelo $A$, não sofrerá clivagem aparecendo intacto com o tamanho de 397 pb. No indivíduo com genótipo homozigoto para o alelo G, o produto do PCR é digerido por completo gerando os fragmento de 245 pb e 152 pb. No indivíduo com genótipo heterozigoto, metade dos produtos gerados no PCR são clivados (aqueles amplificados a 
partir da fita do alelo $\mathrm{G}$ ) enquanto que a outra metade não é clivada, resultando em um padrão com os três fragmentos.

\subsection{Análises Estatísticas}

Após a coleta dos dados genotípicos foi criado um banco de dados em EXCEL. A determinação das freqüências alélicas e genotípicas foram calculadas pela contagem direta. Para avaliar a aderência das proporções genotípicas sob o Equilíbrio de Hardy-Weinberg dos SNPs foi testado, para cada característica, comparando as freqüências genotípicas observadas e esperadas dentro dos dois grupos pelo software GENEPOP 3.4 (RAYMOND \& ROUSSET, 1995). Visando a diferenciação das populações para identificar potenciais associações entre os polimorfismos estudados e as manifestações clínicas consideradas, foi realizado o teste exato de Fisher com auxílio do programa GENEPOP 3.4 (RAYMOND \& ROUSSET, 1995).

Os pares de desequilíbrio de ligação entre os SNPs genotipados (1.000 permutações), os haplótipos formados e suas freqüências foram determinados pelo software Arlequim 3.1 (EXCOFFIER et al., 2005). Para definir melhor o possível motivo de desequilíbrio de ligação entre os SNPs, foram estimados parâmetros tais como: heterozigosidade esperada $(\mathrm{He})$ e observada $(\mathrm{Ho})$ por meio do programa Arlequin (EXCOFFIER et al., 2005).

Para todos os testes utilizados foi considerado a hipótese de nulidade quando a possibilidade de ocorrência casual das diferenças observadas não excedia $5 \%(p<0,05)$. 
A associação de cada haplótipo definido para cada característica foi relacionado entre os dois grupos, caso e controle, utilizando o software estatístico SAS versão 9.13 (SAS, 2003). Assim utilizou-se análise das variância das freqüências dos haplótipos dos dois grupos estudados, adotando o teste de Tukey, com significância de $1 \%(p<0,01)$, para comparação da média entre grupos.

Para todas estas análises levou-se em consideração a idade de prevalência para cada patologia em estudo. Para síndrome torácica aguda e hipertensão pulmonar considerou-se a partir de 10 anos, para priapismo 15 anos, alterações ósseas 13 anos e estenose/AVC 5 anos seguindo a observação na nossa população e literatura a respeito. 


\subsection{Avaliação da modulação de componentes envolvidos na biossíntese da adenosina pela Hidroxiuréia em pacientes com doença falciforme}

\subsubsection{Isolamento de Monócitos do Sangue Periférico}

Foram coletados $35 \mathrm{ml}$ do sangue periférico de cada paciente. Esse material foi aliquotado em 3 tubos falcon e acrescentado de $20 \mathrm{~mL}$ de PBS (0,6\% ACD). Adicionamos nessas amostras $13 \mathrm{~mL}$ de Ficoll-Paque (Amersham Biosciences), após centrifugamos a 2000rpm, por 30 minutos separando as células por diferença em gradiente. Após esse período, o anel de células mononucleares foi recolhido com auxílio de uma pipeta pasteur e transferido para outro tubo falcon. As células mononucleares foram lavadas duas vezes em PBS por 10 minutos e após submetidas a contagem celular.

Obtivemos um número de células mononucleares que são centrifugadas e ressuspendidas em solução tampão (PBS-10\% ACD - 2,5\% albumina).

A marcação desta resuspensão celular foi feita, adicionado $800 \mu$ de solução tampão, $200 \mu \mathrm{l}$ de reagente bloqueador e $200 \mu \mathrm{l}$ de partículas magnéticas ligadas a anticorpos CD14 (microbeads), considerando estes volume para cada $1 \times 10^{8}$ células. Após esta suspensão celular foi incubada a 4 `C por 20 minutos. Estas células foram então lavada s com solução tampão (PBS-10\% ACD - 2,5\% albumina) e ressuspensas em $3 \mathrm{ml}$ de solução tampão para a separação magnética por seleção positiva.

As amostras foram aplicadas na coluna de separação magnética utilizando o kit comercia MACS technology (Miltenyi Biotec-MACS), selecionando positivamente as células de meu interesse, retendo-as na coluna, 
desprezando o restante. A suspensão de monócitos foi centrifugada e ressuspendida em $1 \mathrm{ml}$ de PBS para a contagem celular. A partir desta contagem fez-se a separação de 2 alíquotas para análise da pureza por citometria ( $2 \times 10^{5}$ células) e para extração de RNA ( $6 \times 10^{5}$ células). A alíquota para extração de RNA foi armazenada em Trizol $^{\circledR}$ (Invitrogen - EUA) a - $80^{\circ} \mathrm{C}$ até o seu posterior processamento.

\subsubsection{Avaliação da pureza das células}

Para avaliação da pureza dos monócitos, reservamos $2 \times 10^{5}$ células e em seguida dividida em duas alíquotas para realizarmos a marcação com $4 \mu \mathrm{L}$ dos anticorpos anti-CD14 FITC e anti-CD45 PE (Pharmingen ${ }^{\mathrm{TM}}$ ) e com $4 \mu \mathrm{L}$ dos isotipos controles IgM (FITC) e lgG (PE).

A análise foi realizada no citômetro FACScan (BD Bioscience) e analisados com o software Cell Quest (Becton Dickinson) do laboratório de citometria de fluxo do hemocentro de Ribeirão Preto.

\subsubsection{Extração de RNA}

O ácido ribonucléico (RNA) dos monócitos dos pacientes acima descritos foi extraído de acordo com o método modificado de Chomczynsky e Sancchi, utilizando-se o reagente monofásico Trizol ${ }^{\circledR}$ (Invitrogen - EUA), a base de fenol e Isotiocianato de Guanidina (Chomczynski and Sacchi).

Este foi então ressuspendido em $1 \mathrm{ml}$ de Phosphate Buffer Saline (PBS) [1x] e aliquotados em tubos novos de $1.5 \mathrm{ml}$ livres de RNAse contendo o 
reagente Trizol (Invitrogen, EUA), numa proporção de 3 partes de Trizol para 1 parte de células, e homogeneizados com a auxílio de pipeta. A adição do reagente Trizol a suspensão celular lisa as células mantendo a integridade do RNA. Esta suspensão foi estocada então a -80 C. Para o processamento, primeiro estas amostras são descongeladas a temperatura ambiente e então são acrescidas de $200 \mu \mathrm{l}$ de clorofórmio 100\% (MERCK, EUA), seguida de agitação "vigorosa" por 15 segundos, seguida de centrifugação a 14.000 RPM a $4^{\circ} \mathrm{C}$ por 15 minutos. A adição do clorofórmio separ a a solução de Trizol e células em fase aquosa e fase orgânica. O RNA permanece exclusivamente na fase aquosa. Esta foi então transferida para tubos novos de $1.5 \mathrm{ml}$ livres de RNAse e submetidas à precipitação do RNA com a adição de $500 \mu \mathrm{l}$ de Álcool Isopropílico [100\%], com posterior incubação de 15 minutos. Após a centrifugação a $15.000 \times$ RPM a $4^{\circ} \mathrm{C}$ por 15 minutos e descarte do sobrenadante, o pellet de RNA foi lavado com $1 \mathrm{ml}$ Etanol 70\% e centrifugado a 15.000 RPM a 4 $\mathrm{C}$ por 10 minutos. O sobrenadante foi desprezado por inversão e o pellet secado a temperatura ambiente. Finalmente, esse foi dissolvido em água destilada e deionizada tratada com Dietilpirocarbonato (DEPC) $0,1 \%$ (SIGMA, EUA) e conservado em freezer a -80 , até o uso.

\subsubsection{Quantificação do RNA}

Para mensurar a quantidade de RNA extraído, alíquotas de $2 \mu \mathrm{l}$ de cada amostra foi quantificada no espectofotômetro Nanoveu (GE Helthcare. Foram utilizadas preparações de RNA livres de proteínas, apresentando razão de absorbância $A_{260} / A_{280}$ entre 1.6 e 2.0 livres de fenol com razão $A_{260} / A_{280} \sim 0.7$. 


\subsubsection{Transcrição do DNA Complementar}

Uma vez extraído e quantificado, o RNA foi utilizado para a síntese de DNA complementar (cDNA) com o kit High-Capacity cDNA Archive Kit (Applied Biosystems, EUA). Um micrograma de RNA de cada amostra foi incubado com $2.5 \mu \mathrm{l}$ de 10x RT Buffer, $1 \mu \mathrm{l}$ de 25x dNTP mixture, $2.5 \mu \mathrm{l}$ 10x Random Primers, 0.65 de RNAsin, 1.25 de MultiScribe RT $(50 \mathrm{U} / \mu \mathrm{l})$ e $\mathrm{H}_{2} \mathrm{O}$ tratada com DEPC $0.1 \%$ necessária para completar o volume final de $20 \mu$ durante 10 minutos a $25^{\circ} \mathrm{C}$ e 120 minutos a $37^{\circ} \mathrm{C}$.

\subsubsection{Avaliação dos Níveis Transcricicionais da ADA (RT-PCR)}

Os níveis transcricionais da enzima adenosina deaminase foi avaliada, por PCR em tempo real, nas amostras obtidas de monócitos de pacientes tratados com Hidróxiuréia e pacientes não tratados (8 indivíduos em cada grupo). Esta avaliação foi realizada com o objetivo de confirmar resultados prévios de um estudo que utilizou microarrays de oligonucleotídeos (CodeLink Whole Genome) contendo cerca de 55.000 transcritos, para compararmos os perfis transcricionais de 5 pacientes tratados com Hidroxiuréia e 6 pacientes não tratados. 


\subsubsection{Avaliação da modulação da expressão de CD39, CD73 e} CD26 em linfócitos e monócitos de paciente de AF, frente ao tratamento com HU.

A expressão de CD39, CD73 e CD26 (relacionados com a síntese e degradação de adenosina), foi avaliada por citometria de fluxo, tanto em linfócitos (CD3+) quanto em monócitos (CD14+).

Foram coletadas amostras do sangue periférico de pacientes com anemia falciforme sendo 12 indivíduos sob o uso de HU e 21 sem tratamento. Além disto, 7 indivíduos saudáveis foram utilizados como controle.

Para cada paciente foram utilizado 3 tubos com 150 ul do sangue total. Um tubo controle, contendo isotipos $\mathrm{y}$ (BD Simultest $\left.{ }^{\mathrm{TM}}\right)$, um segundo tubo contendo anticorpos anti-CD3 Pe-CY-5, anti-CD14 FITC, anti-CD39 PE e um terceiro tubo contendo anti-CD3 PE-CY 5, anti-CD14 PE e anti-CD26 FITC (BD Pharmingen ${ }^{\mathrm{TM}}$ ), arranjados para que não houvesse sobreposição das fluorescências. Os tubos foram incubados com 5 ul de cada anticorpo por 15 minutos. Após a marcação, realizamos a lise das hemácias com a solução BD FACS Lysing Solution, agitando vigorosamente. Após um período de 10 minutos no escuro, foi feita a lavagem com $1,5 \mathrm{ml}$ de PBS $1 \mathrm{x}$ com centrifugação de 1.800 RPM por 3 minutos. Desprezou-se o sobrenadante e faz-se a lavagem até obter um botão de células claro, para finalmente ressuspender em 200 ul de PBS 1x e proceder com a análise por citometria de fluxo. 
4. RESULTADOS 


\subsection{Características dos Pacientes}

Ao total foram obtidas 227 amostras de sangue periférico, para extração de DNA, de pacientes com Doença Falciforme (SS e SB9).

Os dados dos pacientes foram coletados com relação à idade, sexo, etnia, diagnóstico e suas manifestações clínicas pela revisão dos prontuários médicos, caracterizando o perfil da população como pode ser observado na tabela 8 .

Tabela 8 - Características demográficas, clínicas e laboratoriais da população em estudo.

\begin{tabular}{cc}
\hline Características & Pacientes (n =227) \\
\hline Idade (anos) & $24.22^{*} \pm 12.39 * *$ \\
Sexo (M/F) & $49.77 \% / 50.23 \%$ \\
Etnia (Branca/Negra/ Mulata) \% & $49.33 / 20.26 / 30.39$ \\
Diagnóstico (SS/SB ${ }^{\circ} \%$ & $78.8 / 21.14$ \\
STA (\%) & 18.50 \\
HIP.PULMONAR (\%) & 17.18 \\
PRIAPISMO (\%) & 10.57 \\
ALT. OSS (\%) & 28.63 \\
ESTENOSE/AVC (\%) & 18.50 \\
\hline
\end{tabular}

*média, ${ }^{* *}$ desvio padrão 


\subsection{Avaliação das Potenciais Associações entre os Polimorfismos Estudados e as Manifestações Clínicas da Doença Falciforme}

A genotipagem de todos os polimorfismos avaliados por PCR em tempo real foi realizada com sucesso em todos os 227 pacientes avaliados. Foram avaliados os 2 SNPs nos genes (ADORA 1 e ADORA 3). A figura 4 ilustra, representativamente, os resultados usualmente obtidos pela técnica de discriminação alélica utilizando o aparelho de PCR em tempo real. Nessa figura, as curvas de amplificação da PCR de amostras de três pacientes com genótipos distintos estão representadas $(a, b, e$ c). A figura d ilustra o agrupamento automático das amostras (feito pelo software), de acordo com o genótipo.

Além disso também fez-se a genotipagem por RFLP do SNP G22A do gene da adenosina deaminase (ADA), como pode ser visualizado na figura 5. 
(a)

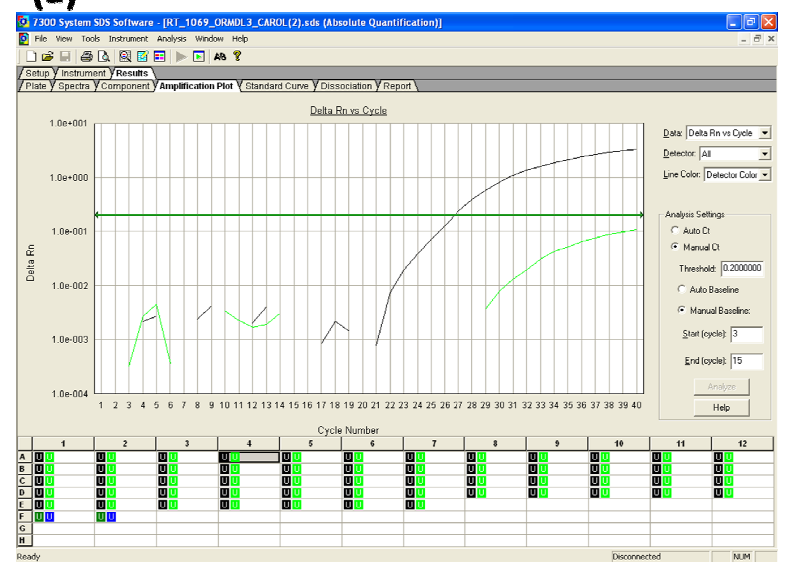

(c)

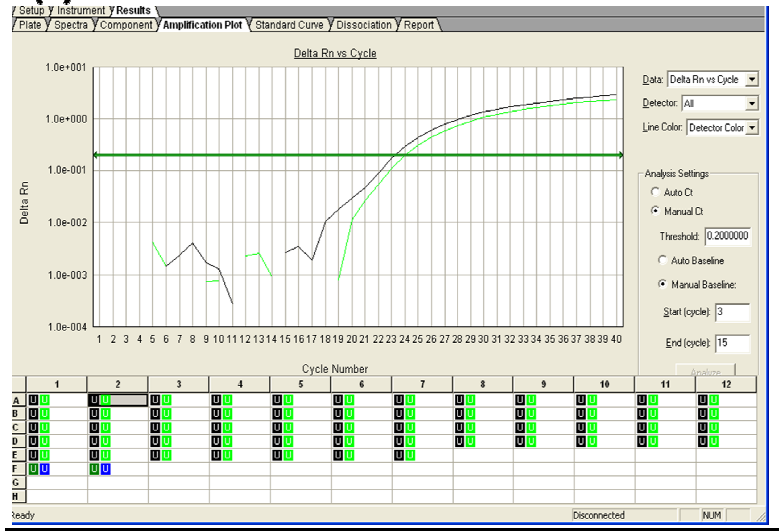

(b)

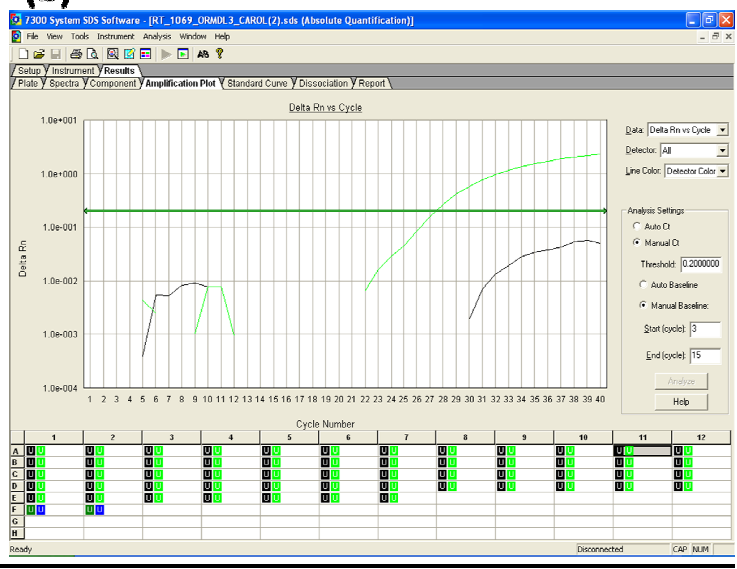

(d)

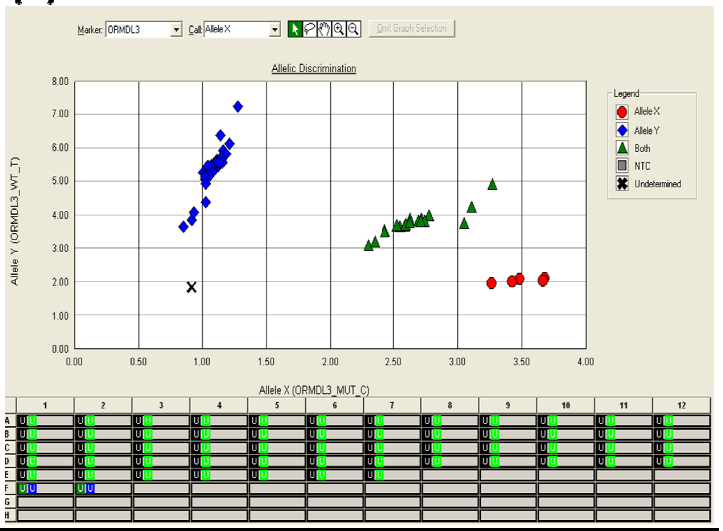

Figura 4. Discriminação alélica por PCR em tempo real. Resultado ilustrativo da genotipagem feita com amostras de pacientes com doença falciforme para o polimorfismo rs16851030 no gene ADORA 1. (a) Curva de amplificação para um Homozigoto "Selvagem" (C/C); (b) Homozigoto "Mutante" (T/T); (c) Heterozigoto (C/T); (d) Agrupamento automático das amostras, de acordo com o genótipo (heterozigotos: triângulos verdes).

(1) (2)

(3)

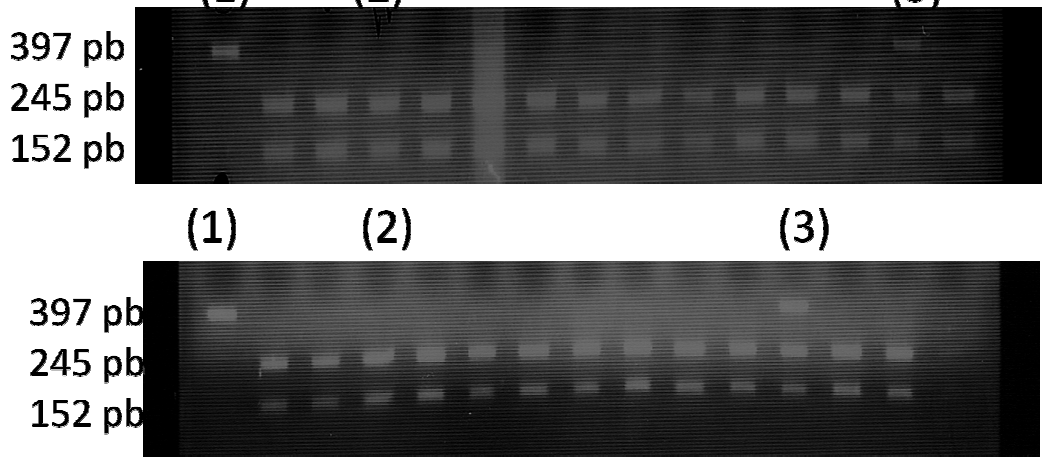

Figura 5. Géis de agarose com resultados representativos da genotipagem realizada por RFLP para o polimorfismo ADA*2. (1) Controle Negativo - produto não digerido 397 pb; (2) Homozigoto G/G, 245 pb e 152 pb; (3) Heterozigoto A/G. 
Após a coleta de informações genotípicas, montaram-se as tabelas de contingência, seguindo com a análise de suas freqüências alélicas e genotípicas para a população não afetada e afetada, como pode ser visto nas tabelas 9 a 13.

Não houve diferenças estatisticamente significativas para a freqüência alélica e genotípica do SNP (rs16851030) do gene ADORA 1 e o SNP do gene ADORA 3 , entre os grupos de pacientes afetados e não afetados para as 5 manifestações clínicas consideradas (Tabelas 9 e 10). Porém uma menor freqüência de pacientes como genótipo $\mathrm{C} / \mathrm{C}$ entre os afetados para a característica STA, ficou evidenciada $(\mathrm{p}=0.128)$.

Com relação aos SNPs do gene ADA (G22A) e do gene ADORA3 (rs35511654), nenhuma diferença associada à síndrome torácica aguda foi encontrada (Tabela 9).

Tabela 9 - Freqüência genotípica dos polimorfismos nos genes ADORA1, ADORA 3 e ADA para Síndrome Torácica Aguda e suas probabilidades de associação entre afetados e não afetados.

\begin{tabular}{|c|c|c|c|c|c|}
\hline \multirow[b]{2}{*}{ Gene } & \multirow[b]{2}{*}{ SNP } & \multirow[b]{2}{*}{ Genótipo } & \multicolumn{2}{|c|}{ Frequência Genotípica } & \multirow{2}{*}{$\begin{array}{l}\text { p valor } \\
\text { CTR vs. STA }\end{array}$} \\
\hline & & & CTR $(n=165)$ & STA $(n=42)$ & \\
\hline \multirow[t]{3}{*}{ ADORA 1} & rs 16851030 & CC & 0.860 & 0.785 & 0.128 \\
\hline & & CT & 0.139 & 0.166 & \\
\hline & & TT & 0 & 0.047 & \\
\hline \multirow[t]{3}{*}{ ADORA 3} & rs35511654 & GG & 0.848 & 0.857 & 1.0 \\
\hline & & GT & 0.151 & 0.142 & \\
\hline & & $\mathrm{TT}$ & 0 & 0 & \\
\hline \multirow[t]{3}{*}{ ADA } & G22A & GG & 0.939 & 0.952 & 1.0 \\
\hline & & GA & 0.060 & 0.047 & \\
\hline & & AA & 0 & 0 & \\
\hline
\end{tabular}


Analisando os casos de hipertensão pulmonar, não houve diferenças genotípicas e alélicas significantes para nenhum dos 3 polimorfismos analisados (Tabela 10)

Tabela 10 - Freqüência genotípica dos polimorfismos nos genes ADORA1, ADORA 3 e ADA para Hipertensão Pulmonar e suas probabilidades de associação entre afetados e não afetados.

\begin{tabular}{cccccc}
\hline & & & \multicolumn{2}{c}{ Frequência Genotípica } & p valor \\
Gene & SNP & Genótipo & CTR ( $\mathbf{n = 1 6 8 )}$ & H.P ( $\mathbf{n = 3 9 )}$ & CTR vs. H.P \\
\hline ADORA 1 & rs16851030 & CC & 0.821 & 0.897 & 0.658 \\
& & CT & 0.160 & 0.076 & \\
ADORA 3 & rs35511654 & GT & 0.0059 & 0.025 & \\
& & GG & 0.857 & 0.820 & 0.615 \\
& & GT & 0.147 & 0.179 & \\
ADA & G 22 A & TT & 0 & 0 & \\
& & GG & 0.940 & 0.948 & 1.0 \\
& & GA & 0.059 & 0.051 & \\
& & AA & 0 & 0 & \\
\hline
\end{tabular}

Analisando o SNP G 22 A no gene ADA, não pudemos identificar diferenças significativas para o teste de associação com nenhuma das características analisadas, porém houve uma aumento da freqüência genotípica de $G / A$ e diminuição do genótipo $G / G$ entre ao afetados para priapismo $(p=0.602)$ (Tabelas 11).

Na tabela 11 podemos notar também um diminuição da freqüência genotípica $\mathrm{C} / \mathrm{T}$ e $\mathrm{T} / \mathrm{T}$ e aumento da freqüência de $\mathrm{C} / \mathrm{C}$ entre os afetados com priapismo para o SNP do gene ADORA $1(\mathrm{p}=0.793)$ 
Tabela 11 - Freqüência genotípica dos polimorfismos nos genes ADORA1, ADORA 3 e ADA para priapismo e suas probabilidades de associação entre afetados e não afetados.

\begin{tabular}{|c|c|c|c|c|c|}
\hline \multirow[b]{2}{*}{ Gene } & \multirow[b]{2}{*}{ SNP } & \multirow[b]{2}{*}{ Genótipo } & \multicolumn{2}{|c|}{ Frequência Genotípica } & \multirow{2}{*}{$\begin{array}{l}\text { p valor } \\
\text { CTR vs. } \\
\text { PRIAP }\end{array}$} \\
\hline & & & CTR $(n=69)$ & PRIAP. $(n=24)$ & \\
\hline \multirow[t]{3}{*}{ ADORA 1} & rs 16851030 & $\mathrm{CC}$ & 0.811 & 0.833 & 0.793 \\
\hline & & CT & 0.173 & 0.166 & \\
\hline & & TT & 0.014 & 0 & \\
\hline \multirow[t]{3}{*}{ ADORA 3} & rs35511654 & GG & 0.869 & 0.875 & 1.0 \\
\hline & & GT & 0.130 & 0.125 & \\
\hline & & TT & 0 & 0 & \\
\hline \multirow[t]{3}{*}{ ADA } & G $22 \mathrm{~A}$ & GG & 0.926 & 0.916 & 0.602 \\
\hline & & GA & 0.044 & 0.083 & \\
\hline & & AA & 0 & 0 & \\
\hline
\end{tabular}

Observando os casos de alterações ósseas associado ao SNP do genes ADORA 1, existe um diminuição da freqüência genotípica de $C / T$ e $T / T$ entre os pacientes não afetados ( $\mathrm{p}=0.698)$ (Tabela 12).

Observa-se também um aumento da freqüência genotípica $G / A$ e diminuição do genótipo $\mathrm{G} / \mathrm{G}$ no gene da $A D A$, relacionado com alterações ósseas entre os grupo de pacientes afetados ( $p=0.525)$ (Tabela 12).

Tabela 12 - Freqüência genotípica dos polimorfismos nos genes ADORA1, ADORA 3 e ADA para alterações ósseas e suas probabilidades de associação entre afetados e não afetados.

\begin{tabular}{cccccc}
\hline Gene & SNP & Genótipo & CTR ( $\mathbf{n = 1 3 1 )}$ & ALT.OSS ( $\mathbf{n = 6 3 )}$ & $\begin{array}{c}\text { p valor } \\
\text { CTR vs.ALT.OSS }\end{array}$ \\
\hline ADORA 1 & rs16851030 & CC & 0.838 & 0.857 & 0.698 \\
& & CT & 0.146 & 0.142 & \\
ADORA 3 & rs35511654 & TT & 0.015 & 0 & \\
& & GG & 0.847 & 0.873 & 0.672 \\
& & GT & 0.152 & 0.126 & \\
ADA & G 22 A & TT & 0 & 0 & 0.525 \\
& & GG & 0.946 & 0.918 & \\
& & GA & 0.053 & 0.081 & \\
\hline
\end{tabular}


Para a característica estenose/AVC, houve um aumento da freqüência dos genótipos C/T e T/T para o polimorfismo rs16851030 do gene ADORA 1 entre os pacientes afetados $(p=0.511)$ (Tabela 13).

É possível notar na tabela 13 , uma aumento da freqüência genotípica G/G entre os pacientes afetados para estenose/AVC para este SNP no gene ADA, e uma diminuição dos genótipos $G / A(p=0.469)$.

Tabela 13 - Freqüência genotípica dos polimorfismos nos genes ADORA1, ADORA 3 e ADA para estenose/AVC e suas probabilidades de associação entre afetados e não afetados

\begin{tabular}{|c|c|c|c|c|c|}
\hline \multirow[b]{2}{*}{ Gene } & \multirow[b]{2}{*}{ SNP } & \multirow[b]{2}{*}{ Genótipo } & \multicolumn{2}{|c|}{ Frequência Genotípica } & \multirow{2}{*}{$\begin{array}{c}\text { p valor } \\
\text { CTR vs. AVC }\end{array}$} \\
\hline & & & CTR $(n=178)$ & ESTENOSE/ AVC $(n=42)$ & \\
\hline \multirow{3}{*}{ ADORA 1} & rs16851030 & CC & 0.848 & 0.809 & 0.519 \\
\hline & & CT & 0.146 & 0.166 & \\
\hline & & TT & 0.005 & 0.023 & \\
\hline \multirow[t]{3}{*}{ ADORA 3} & rs35511654 & GG & 0.853 & 0.833 & 0.810 \\
\hline & & GT & 0.146 & 0.166 & \\
\hline & & TT & 0 & 0 & \\
\hline \multirow[t]{3}{*}{ ADA } & G $22 \mathrm{~A}$ & GG & 0.938 & 0.976 & 0.469 \\
\hline & & GA & 0.061 & 0.023 & \\
\hline & & AA & 0 & 0 & \\
\hline
\end{tabular}

Como podemos observar nas tabela 9,10,11,12 e 13, não identificamos diferenças significativas nas freqüências alélicas e genotípica do SNP localizado no gene ADORA 3 (rs35511654), assim com para o teste de associação nenhum valor de $\mathrm{p}$ foi relevante para qualquer das característica analisada.

Os dados foram analisados quanto a sua aderência ao Equilíbrio de Hardy-Weinberg e todos aderiram ao equilíbrio $(\mathrm{p}<0.05)$. 


\subsection{Detecção de polimorfismos no gene ADORA $2 B$ e suas} associações com as manifestações clinicas da doença falciforme

A pesquisa por polimorfismos no gene de receptor de adenosina $2 \mathrm{~B}$ foi avaliada por seqüenciamento do produto amplificado de cada éxon de 96 pacientes e foi seqüenciado tanto a seqüência direta quanto a reversa.

Foi possível identificar dois SNPs no primeiro éxon que compõem o gene ADORA 2B : + $968 \mathrm{G}>\mathrm{T}$, + $1007 \mathrm{C}>\mathrm{T}$ (Figura 6 e 7). Sendos estas, mutações silenciosas.

\section{$\mathrm{SNP}+968 \mathrm{G}>\mathrm{T}$}

Sequência Referência

A CAGGACGCGCTGTACGTGGCGCTGGAGCTGGTCATCGCCGCGCTTTCG

Conflict

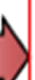

ACAGGACGCGCTGTACGTGGCTCTGGAGCTGGTCATCGCCGCGCTTTCG

Homozigoto Mutante $(T / T)$

A C A G G A C G C G C T G TACG T G G CTC T G G A G C T G G T CA T C G C C G C G C T T T C G

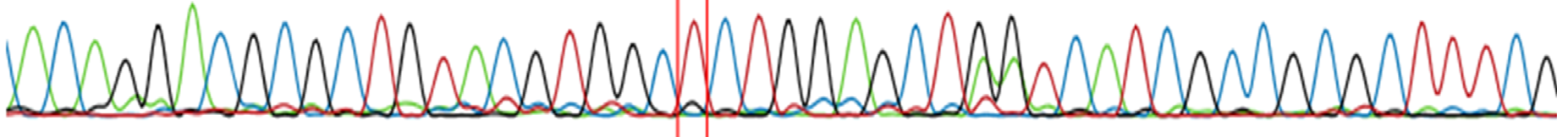

Figura 6. Cromatograma do seqüenciamento com os polimorfismos + $968 \mathrm{G}>\mathrm{T}$ identificado no éxon 1 do gene ADORA 2B. 


\section{SNP + $1007 \mathrm{C}>\mathrm{T}$}

Sequência Referência

TCATCGCCGCGCTTTCGGTGGCGGGCAACGTGCTGGTGTGCGCCGCGGT

TCATCGCCGCGCTTTCGGTGGCGGGCAATGTGCTGGTGTGCGCCGCGGT Homozigoto Mutante (T/T)

TCATCGCCGCGCTTTCGGTGGCGGGCAATGTGCTGGTGTGCGCCGCGGT

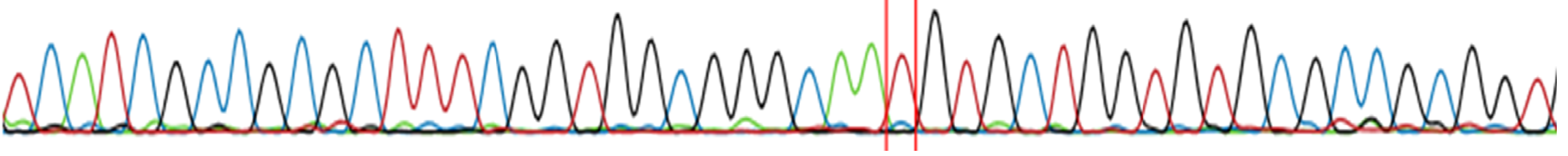

Figura 7. Cromatograma do seqüenciamento com os polimorfismos $+1007 \mathrm{C}>\mathrm{T}$ identificado no éxon 1 do gene ADORA 2B.

Após a confirmação dos dados da genotipagem por seqüenciamento das 227 amostras, para estes dois SNPs procedeu-se a análise com o cálculo das freqüências alélicas e genotípicas e suas respectivas associação com as manifestações clínicas em estudo.

Estes polimorfismos foram testados quanto à aderência ao Equilíbrio de Hardy-Weinberg para as duas populações (afetada e não afetada), e notamos que o SNP 1007 C>T está em desequilíbrio para todas as características tanto no grupo de afetados quanto não afetados, já para o SNP 968 G>T a população não afetada para priapismo aderiu ao equilíbrio porém a população afetada não aderiu. Para associação como alterações ósseas e estenose/AVC 
a população afetada aderiu ao equilíbrio enquanto a população não afetada se encontra em desequilíbrio.

Pudemos observar um aumento da freqüência do alelo T para o SNP (1007 C>T) entre o grupo dos afetados com síndrome torácica aguda, apresentando um valor significativo de $p=0.032$. Podendo indicar um possível alelo de risco para esta característica (Tabela 14). Olhando para a freqüência genotípica o valor de $p$ não foi significativo, possivelmente pela amostragem insuficiente (Tabela 15).

Tabela 14 - Freqüência alélica dos polimorfismos no gene ADORA 2B para síndrome torácica aguda e suas probabilidades de associação entre afetados e não afetados

\begin{tabular}{cccccc}
\hline & & & \multicolumn{2}{c}{ Frequência Alélica } & p valor \\
Gene & SNP & Alelo & CTR $(\mathbf{n}=\mathbf{1 6 5})$ & STA $(\mathbf{n}=\mathbf{4 2})$ & CTR vs. STA \\
\hline ADORA 2B & $968 \mathrm{G}>\mathrm{T}$ & $\mathrm{G}$ & 0.921 & 0.881 & 0.271 \\
& & $\mathrm{~T}$ & 0.078 & 0.119 & \\
ADORA 2B & \multirow{2}{*}{$1007 \mathrm{C}>\mathrm{T}$} & $\mathrm{C}$ & 0.897 & 0.809 & $\mathbf{0 . 0 3 2}$ \\
& & $\mathrm{T}$ & 0.095 & 0.190 & \\
\hline
\end{tabular}

Tabela 15 - Freqüência genotípica dos polimorfismos no gene ADORA 2B para síndrome torácica aguda e suas probabilidades de associação entre afetados e não afetados

\begin{tabular}{cccccc}
\hline \multirow{2}{*}{ Gene } & SNP & Genótipo & CTR $(\mathbf{n}=\mathbf{1 6 5})$ & STA(n= 42) & CTR vs. STA \\
\hline ADORA 2B & 968 G>T & GG & 0.875 & 0.769 & 0.345 \\
& & GT & 0.095 & 0.205 & \\
ADORA 2B & \multirow{2}{*}{1007 C $>$ T } & TT & 0.029 & 0.025 & \\
& & CC & 0.890 & 0.809 & 0.161 \\
& & CT & 0.012 & 0 & \\
& TT & 0.096 & 0.190 & \\
\hline
\end{tabular}


Houve um aumento da freqüência genotípica de $G / T$, T/T e diminuição do genótipo G/G do SNP 968 G>T para o grupo com hipertensão pulmonar, porém a associação não foi significativa $(\mathrm{p}=0.242)$ (Tabela 16).

Para o SNP 1007 C>T não houve diferenças significativas de freqüência alélica e genotípica para esta característica, mas observamos uma aumento do genótipo $T / T$ entre os afetados com hipertensão pulmonar $(p=0.282)$ (Tabela 16).

Tabela 16 - Freqüência genotípica dos polimorfismos no gene ADORA 2B para hipertensão pulmonar e suas probabilidades de associação entre afetados e não afetados.

\begin{tabular}{cccccc}
\hline & & & \multicolumn{2}{c}{ Frequência Genotípica } & p valor \\
Gene & SNP & Genótipo & CTR ( $\mathbf{n = 1 6 8 )}$ & H.P ( $\mathbf{n = 3 9 )}$ & CTR vs. H.P \\
\hline ADORA 2B & 968 G>T & GG & 0.875 & 0.769 & 0.242 \\
& & GT & 0.095 & 0.205 & \\
ADORA 2B & \multirow{2}{*}{1007 C>T } & TT & 0.005 & 0.025 & \\
& & CC & 0.886 & 0.820 & 0.282 \\
& & CT & 0.011 & 0 & \\
& & TT & 0.101 & 0.179 & \\
\hline
\end{tabular}

Como podemos observar na tabela 17, não foram encontradas diferenças relevantes de freqüência para os dois SNPs relacionados ao priapismo. Porém existe uma diminuição do genótipo G/T e um aumento da freqüência de $G / G$ entre os afetados ( $p=0.773$ ) para o SNP $968 \mathrm{G}>\mathrm{T}$. 
Tabela 17 - Freqüência genotípica dos polimorfismos no gene ADORA 2B para priapismo e suas probabilidades de associação entre afetados e não afetados.

\begin{tabular}{cccccc}
\hline Gene & SNP & Genótipo & CTR $(\mathbf{n}=69)$ & PRIAP $(\mathbf{n}=\mathbf{2 4})$ & CTR vs. PRIAP \\
\hline ADORA 2B & $968 \mathrm{G}>\mathrm{T}$ & GG & 0.814 & 0.913 & 0.773 \\
& & GT & 0.185 & 0.043 & \\
ADORA 2B & & TT & 0 & 0.043 & \\
& 1007 C>T & CC & 0.826 & 0.173 & 0.352 \\
& & CT & 0 & 0 & \\
& & TT & 0.173 & 0.086 & \\
\hline
\end{tabular}

$\mathrm{Na}$ tabela 18 podemos verificar uma diminuição significativa da freqüência genotípica de G/T e T/T do polimorfismo 968 G>T para o grupo com alterações ósseas em relação a grupo sem esta alteração $(p=0.0043)$, indicando o genótipo G/G para um risco maior em desenvolver tal patologia.

Para o SNP 1007 C>T também é possível notar uma diferença relevante das freqüências, onde existe um aumento dos genótipos $\mathrm{C} / \mathrm{C}$ e $\mathrm{C} / \mathrm{T}$ e diminuição do genótipo T/T entre o grupo com alterações ósseas para o grupo $(p=0.013)$, indicando $o$ alelo $C$ para um risco aumentado para $o$ desenvolvimento de alterações ósseas (Tabela 18).

Tabela 18 - Freqüência genotípica dos polimorfismos no gene ADORA 2B para alterações ósseas e suas probabilidades de associação entre afetados e não afetados.

\begin{tabular}{cccccc}
\hline Gene & SNP & Genótipo & CTR $(\mathbf{n}=\mathbf{1 3 1})$ & ALT.OSS $(\mathbf{n}=\mathbf{6 3})$ & CTR vs.ALT.OSS \\
\hline ADORA 2B & $968 \mathrm{G}>\mathrm{T}$ & GG & 0.807 & 0.952 & $\mathbf{0 . 0 0 4 3}$ \\
& & GT & 0.153 & 0.047 & \\
ADORA 2B & \multirow{2}{*}{$1007 \mathrm{C}>\mathrm{T}$} & $\mathrm{TT}$ & 0.038 & 0 & \\
& & CC & 0.838 & 0.952 & $\mathbf{0 . 0 1 3}$ \\
& & CT & 0.007 & 0.015 & \\
\hline & TT & 0.153 & 0.031 & \\
\hline
\end{tabular}


Observando a característica de estenose/acidente vascular cerebral, podemos notar que apesar de não encontrarmos diferenças significante entre os dois grupos ( $p=0.126)$, existe um aumento da freqüência genotípica de $G / G$ entre o grupo afetado e aumento dos genótipos $G / T$ e $T / T$ entre os não afetados, para o SNP $968 \mathrm{G}>\mathrm{T}$, indicando o alelo $\mathrm{G}$ para um maior risco de desenvolver esta característica (Tabela 19).

Para o SNP 1007 C>T, existe um aumento da freqüência genotípica de C/C e C/T e diminuição de $\mathrm{T} / \mathrm{T}$ entre os afetados, porém a diferença entre os dois grupos não foi significativa $(p=0.192)$ (Tabela 19).

Tabela 19 - Freqüência genotípica dos polimorfismos no gene ADORA 2B para estenose/AVC e suas probabilidades de associação entre afetados e não afetados.

\begin{tabular}{|c|c|c|c|c|c|}
\hline \multirow[b]{2}{*}{ Gene } & \multirow[b]{2}{*}{ SNP } & \multirow[b]{2}{*}{ Genótipo } & \multicolumn{2}{|c|}{ Frequência Genotípica } & \multirow{2}{*}{$\begin{array}{c}\text { p valor } \\
\text { CTR vs. AVC }\end{array}$} \\
\hline & & & CTR $(n=178)$ & ESTENOSE/ AVC $(n=42)$ & \\
\hline \multirow[t]{3}{*}{ ADORA 2B } & $968 \mathrm{G}>\mathrm{T}$ & GG & 0.842 & 0.928 & 0.126 \\
\hline & & GT & 0.123 & 0.071 & \\
\hline & & TT & 0.033 & 0 & \\
\hline \multirow[t]{3}{*}{ ADORA 2B } & $1007 \mathrm{C}>\mathrm{T}$ & CC & 0.865 & 0.928 & 0.192 \\
\hline & & CT & 0.011 & 0.023 & \\
\hline & & TT & 0.123 & 0.047 & \\
\hline
\end{tabular}




\subsection{Detecção e Associação de Haplótipos}

Considerando os polimorfismos descritos calculou-se o desequilíbrio de ligação entre os SNPs que estivessem no mesmo cromossomo para verificar a possível formação de haplótipos e suas associações.

Entre estes, pudemos identificar nos dois grupos (afetados e não afetados) um elevado desequilíbrio de ligação entre os 2 SNPs identificados no gene ADORA 2B (968 G>T e 1007 C>T) (tabela 20), para todas a patologias estudadas, possibilitando uma inferência probabilística de haplótipos.

Uma outra análise foi feita entres os 3 SNPs presentes no cromossomo 17, sendo estes: rs16851030 no gene ADORA 1, 968 G>T e 1007 C>T no gene ADORA 2B. Encontramos um desequilíbrio de ligação entre esses 3 SNPs relacionado ao priapismo no grupo dos não afetados $(p=0.010)$ e para estenose/AVC no grupo dos afetados $(p=0.010)$ (Tabela 21)

De uma forma geral os resultados da heterozigosidade observada estão diminuídas, tanto entre o grupo dos afetados quanto no grupo controle (Tabela 20 e 21).

Apenas entre os afetados para hipertensão pulmonar, alterações ósseas e estenose/AVC para o polimorfismo 968 G>T e para priapismo dentro dos dois grupos é que a heterozigosidade estava dentro do esperado aderindo ao equilíbrio de Hardy-Weinberg (Tabela 20).

Para o polimorfismo do gene ADORA 1 para todas as características analisadas os resultados da heterozigosidade observadas estavam dentro do esperado, aderindo ao equilíbrio de Hardy-Weinberg (Tabela 21). 
Tabela 20 - Diversidade Genética para todas as manifestações clínicas obtidas a partir dos SNP 968 G>T e 1007 C>T do gene ADORA 2B. Heterozigosidade observada (Ho), heterozigosidade esperada (He), EHW valores de $\mathrm{p}$ obtidos no teste de Equilíbrio de Hardy-Weinberg $(p<0,05)$, DL desequilíbrio de ligação $(p<0,05)$.

\begin{tabular}{|c|c|c|c|c|c|c|c|c|c|c|c|}
\hline \multirow[t]{2}{*}{ GENE } & \multirow[t]{2}{*}{ Manif.Clínica } & \multirow[t]{2}{*}{ Locus } & \multirow[t]{2}{*}{$\mathrm{Cr}$} & \multicolumn{2}{|c|}{ Ho } & \multicolumn{2}{|c|}{$\mathrm{He}$} & \multicolumn{2}{|c|}{ EHW } & \multicolumn{2}{|c|}{ DL } \\
\hline & & & & A & N.A & A & N.A & A & N.A & A & N.A \\
\hline & STA & $\begin{array}{c}968 \mathrm{G}>\mathrm{T} \\
1007\end{array}$ & 17 & 0.146 & 0.113 & 0.216 & 0.144 & 0.085 & 0.015 & 0.00000 & 0.00000 \\
\hline & & $\mathrm{C}>\mathrm{T}$ & 17 & 0.000 & 0.016 & 0.317 & 0.180 & 0.000 & 0.000 & & \\
\hline & H.P & $\begin{array}{c}968 \mathrm{G}>\mathrm{T} \\
1007\end{array}$ & 17 & 0.205 & 0.101 & 0.226 & 0.142 & 0.483 & 0.001 & 0.00000 & 0.00000 \\
\hline & & $\mathrm{C}>\mathrm{T}$ & 17 & 0.000 & 0.015 & 0.298 & 0.186 & 0.000 & 0.000 & & \\
\hline & PRIAP & $\begin{array}{c}968 \mathrm{G}>\mathrm{T} \\
1007\end{array}$ & 17 & 0.041 & 0.179 & 0.119 & 0.182 & 0.063 & 1.000 & 0.00002 & 0.00000 \\
\hline \multirow[t]{5}{*}{ ADORA 2B } & & $\mathrm{C}>\mathrm{T}$ & 17 & 0.000 & 0.022 & 0.156 & 0.281 & 0.001 & 0.000 & & \\
\hline & ALT OSS & $\begin{array}{c}968 \mathrm{G}>\mathrm{T} \\
1007\end{array}$ & 17 & 0.046 & 0.148 & 0.045 & 0.198 & 1.000 & 0.005 & 0.00001 & 0.00000 \\
\hline & & $\mathrm{C}>\mathrm{T}$ & 17 & 0.015 & 0.012 & 0.074 & 0.253 & 0.000 & 0.000 & & \\
\hline & ESTENOSE/AVC & $\begin{array}{c}968 \mathrm{G}>\mathrm{T} \\
1007\end{array}$ & 17 & 0.071 & 0.129 & 0.069 & 0.176 & 1.000 & 0.002 & 0.00002 & 0.00000 \\
\hline & & $C>T$ & 17 & 0.023 & 0.010 & 0.113 & 0.226 & 0.002 & 0.000 & & \\
\hline
\end{tabular}


Tabela 21 - Diversidade Genética para todas as manifestações clínicas obtidas a partir dos SNP 968 G>T , 1007 C>T, rs16851030 do gene ADORA 2B e ADORA 1. Heterozigosidade observada $(\mathrm{Ho})$, heterozigosidade esperada $(\mathrm{He})$, EHW valores de $p$ obtidos no teste de Equilíbrio de Hardy-Weinberg ( $\mathrm{H}<0,05)$, DL desequilíbrio de ligação $(p<0,05)$.

\begin{tabular}{|c|c|c|c|c|c|c|c|c|c|c|c|}
\hline \multirow[t]{2}{*}{ GENE } & \multirow[t]{2}{*}{ Manif.Clínica } & \multirow[t]{2}{*}{ Locus } & \multirow[t]{2}{*}{$\mathrm{Cr}$} & \multicolumn{2}{|c|}{$\mathrm{Ho}$} & \multicolumn{2}{|c|}{$\mathrm{He}$} & \multicolumn{2}{|c|}{ EHW } & \multicolumn{2}{|c|}{ DL } \\
\hline & & & & $\mathbf{A}$ & N.A & $\mathbf{A}$ & N.A & $\mathbf{A}$ & N.A & $\mathbf{A}$ & N.A \\
\hline & STA & rs16851030 & 17 & 0.170 & 0.141 & 0.235 & 0.131 & 0.127 & 0.604 & 0.85991 & 0.11087 \\
\hline & & $968 \mathrm{G}>\mathrm{T}$ & 17 & 0.146 & 0.114 & 0.216 & 0.145 & 0.085 & 0.016 & & \\
\hline & & $1007 \mathrm{C}>\mathrm{T}$ & 17 & 0.000 & 0.016 & 0.317 & 0.181 & 0.000 & 0.000 & & \\
\hline & H.P & rs16851030 & 17 & 0.078 & 0.159 & 0.124 & 0.156 & 0.130 & 1.000 & 0.24186 & 0.10946 \\
\hline & & $968 \mathrm{G}>\mathrm{T}$ & 17 & 0.210 & 0.101 & 0.231 & 0.142 & 0.493 & 0.000 & & \\
\hline & & $1007 \mathrm{C}>\mathrm{T}$ & 17 & 0.000 & 0.015 & 0.304 & 0.186 & 0.000 & 0.000 & & \\
\hline \multirow{9}{*}{$\begin{array}{c}\text { ADORA1/ADORA } \\
\text { 2B }\end{array}$} & PRIAP & rs16851030 & 17 & 0.173 & 0.181 & 0.162 & 0.184 & 1.000 & 1.000 & 0.45211 & 0.01036 \\
\hline & & $968 \mathrm{G}>\mathrm{T}$ & 17 & 0.043 & 0.181 & 0.124 & 0.184 & 0.066 & 0.000 & & \\
\hline & & $1007 \mathrm{C}>\mathrm{T}$ & 17 & 0.000 & 0.022 & 0.162 & 0.284 & 0.001 & 0.000 & & \\
\hline & ALT OSS & rs16851030 & 17 & 0.140 & 0.149 & 0.131 & 0.159 & 1.000 & 0.332 & 0.33166 & 0.11848 \\
\hline & & $968 \mathrm{G}>\mathrm{T}$ & 17 & 0.046 & 0.149 & 0.046 & 0.199 & 1.000 & 0.005 & & \\
\hline & & $1007 \mathrm{C}>\mathrm{T}$ & 17 & 0.015 & 0.012 & 0.075 & 0.254 & 0.000 & 0.000 & & \\
\hline & ESTENOSE/AVC & rs16851030 & 17 & 0.170 & 0.141 & 0.197 & 0.140 & 0.388 & 1.000 & 0.01022 & 0.27084 \\
\hline & & $968 \mathrm{G}>\mathrm{T}$ & 17 & 0.073 & 0.130 & 0.071 & 0.176 & 1.000 & 0.002 & & \\
\hline & & $1007 \mathrm{C}>\mathrm{T}$ & 17 & 0.024 & 0.010 & 0.115 & 0.227 & 0.002 & 0.000 & & \\
\hline
\end{tabular}


A partir destes resultados, seguimos como a inferência dos possíveis haplótipos entre estes polimorfismos. Em primeira análise entre os SNPs 968 G>T e 1007 C>T, houve a formação de 4 haplótipos para todas as manifestações clínicas, variando suas freqüências haplotípicas para cada grupo (afetados e não afetados) (Tabela 22).

Em segunda análise para os 3 SNPs rs16851030, 968 G>T e 1007 C>T do cromossomo 17, observamos a formação de 7 haplótipos para priapismo e 8 haplótipos para a patologia estenose/AVC. Os haplótipos encontrados, suas freqüências e as probabilidades de associação com os diferentes grupos estão na tabela 23.

Na primeira análise de haplótipos com os SNP do gene ADORA 2B, houve associação haplotípica significante de ht2 [G-T] e ht3 [T-T] mostrando-se como fator de risco e o ht1 [G-C] como fator protetor $(p<0.01)$ para os pacientes afetados com síndrome torácica aguda, hipertensão pulmonar e priapismo. Para alterações ósseas o ht1 [G-C] foi associado significativamente como fator de risco e ht2 [G-T] e ht3 [T-T] como fatores protetores $(p<0.01)$. E finalmente para estenose/AVC o haplótipo ht1 [G-C] foi associado como fator de risco e ht3 $[T-T]$ como fator protetor $(p<0.01)$ (Tabela 22$)$. 
Tabela 22 - Haplótipos do gene ADORA 2B e suas freqüências entre os grupos de pacientes falciformes.

\begin{tabular}{|c|c|c|c|c|}
\hline \multirow[b]{2}{*}{ Manif.Clínica } & \multirow[b]{2}{*}{ locus } & \multirow[b]{2}{*}{ Haplótipo } & \multicolumn{2}{|c|}{ Frequência } \\
\hline & & & Afetados & Não Afetados \\
\hline \multirow[t]{4}{*}{ STA } & & ht1 [G-C ] & 0.804 & $0.883^{*}$ \\
\hline & $968 \mathrm{G}>\mathrm{T}$ & ht2 [ G - T ] & $0.073^{*}$ & 0.037 \\
\hline & $1007 \mathrm{C}>\mathrm{T}$ & $\mathrm{ht3}[\mathrm{T}-\mathrm{T}]$ & $0.121^{*}$ & 0.062 \\
\hline & & h4 [ T - C ] & 0 & 0.016 \\
\hline \multirow[t]{4}{*}{ H.P } & & ht1 [ G - C ] & 0.794 & $0.885^{\star}$ \\
\hline & $968 \mathrm{G}>\mathrm{T}$ & ht2 [ G - T ] & $0.076^{*}$ & 0.037 \\
\hline & $1007 \mathrm{C}>\mathrm{T}$ & $\mathrm{ht} 3[\mathrm{~T}-\mathrm{T}]$ & $0.102^{*}$ & 0.066 \\
\hline & & $\mathrm{h} 4[\mathrm{~T}-\mathrm{C}]$ & 0.00 & 0.010 \\
\hline \multirow[t]{4}{*}{ PRIAP. } & & ht1 [ G - C ] & $0.916^{*}$ & 0.820 \\
\hline & $968 \mathrm{G}>\mathrm{T}$ & ht2 [ G - T ] & 0.020 & $0.078^{*}$ \\
\hline & $1007 \mathrm{C}>\mathrm{T}$ & $\mathrm{ht} 3[\mathrm{~T}-\mathrm{T}$ ] & 0.062 & $0.089^{*}$ \\
\hline & & $\mathrm{h} 4[\mathrm{~T}-\mathrm{C}]$ & 0 & 0.011 \\
\hline \multirow[t]{4}{*}{ ALT OSS } & & ht1 [ G - C ] & $0.961^{*}$ & 0.833 \\
\hline & $968 \mathrm{G}>\mathrm{T}$ & ht2 [ G - T ] & 0.015 & $0.037^{*}$ \\
\hline & $1007 \mathrm{C}>\mathrm{T}$ & $\mathrm{ht} 3[\mathrm{~T}-\mathrm{T}]$ & 0.015 & $0.117^{*}$ \\
\hline & & $\mathrm{h} 4[\mathrm{~T}-\mathrm{C}]$ & 0.00 & 0.018 \\
\hline \multirow[t]{4}{*}{ Estenose/AVC } & & ht1 [ G - C ] & $0.940^{*}$ & 0.854 \\
\hline & $968 \mathrm{G}>\mathrm{T}$ & ht2 [ G - T ] & 0.00 & 0.064 \\
\hline & $1007 \mathrm{C}>\mathrm{T}$ & $\mathrm{ht} 3[\mathrm{~T}-\mathrm{T}]$ & 0.035 & $0.081^{*}$ \\
\hline & & $\mathrm{h} 4[\mathrm{~T}-\mathrm{C}]$ & 0 & 0.016 \\
\hline
\end{tabular}

*Teste de Tukey, controlando erro do tipo I, com significância de $1 \%(p<0.01)$

Em segunda análise considerando todos os 3 SNPs, notamos que afetados com estenose da artéria cerebral média ou acidente vascular cerebral, apresentaram associação significante dos haplótipos ht1 [C G C] e ht6 [T G T] como fator de risco e ht2 [C G T], ht4 [C T T] e ht5 [T G C] como fatores protetores $(p<0.01)$. Os pacientes que apresentavam priapismo estavam associados com os haplótipos ht1 [C G C], ht3 [C T T] e ht4 [T G C] como fatores de risco e o ht $2[\mathrm{C} \mathrm{G} \mathrm{T]} \mathrm{como} \mathrm{fator} \mathrm{protetor} \mathrm{presente} \mathrm{entre} \mathrm{os} \mathrm{não}$ afetados (Tabela 23). 
Tabela 23 - Haplótipos dos genes ADORA 1 e ADORA 2B para priapismo e estenose/AVC e suas freqüências entre os grupos de pacientes falciformes.

\begin{tabular}{|c|c|c|c|c|c|}
\hline \multirow[b]{2}{*}{ Gene } & \multirow[b]{2}{*}{ Manif.Clínica } & \multirow[b]{2}{*}{ locus } & \multirow[b]{2}{*}{ Haplótipo } & \multicolumn{2}{|c|}{ Frequência } \\
\hline & & & & Afetados & Não Afetados \\
\hline & & & ht 1 [C G C] & $0.913^{*}$ & 0.750 \\
\hline & & & ht 2 [C G T] & 0.043 & $0.102^{*}$ \\
\hline & & $968 \mathrm{G}>\mathrm{T}$ & ht3 [C T T] & $0.043^{*}$ & 0.034 \\
\hline & PRIAP. & $1007 \mathrm{C}>\mathrm{T}$ & ht 4 [T G C] & $0.173^{*}$ & 0.045 \\
\hline & & rs16851030 & ht 5 [T G T] & 0 & 0.012 \\
\hline & & & ht 6 [T T C] & 0 & 0.011 \\
\hline & & & ht 7 [ T T T] & 0 & 0.020 \\
\hline \multicolumn{6}{|c|}{$\begin{array}{c}\text { ADORA } \\
\text { 1/ADORA2B }\end{array}$} \\
\hline & & & h1 [C G C] & $0.878^{*}$ & 0.788 \\
\hline & & & $\mathrm{h} 2$ [C G T] & 0.024 & $0.038^{*}$ \\
\hline & & $968 \mathrm{G}>\mathrm{T}$ & h3 [C T C] & 0 & 0.027 \\
\hline & Estenose/AVC & $1007 \mathrm{C}>\mathrm{T}$ & h4 [C T T] & 0.024 & $0.092^{*}$ \\
\hline & & rs16851030 & h5 [T G C] & 0.048 & $0.054^{*}$ \\
\hline & & & h6 [T G T] & $0.024^{*}$ & 0.010 \\
\hline & & & $\mathrm{h} 7[\mathrm{~T} \mathrm{~T} \mathrm{C}]$ & 0 & 0.005 \\
\hline & & & h8 [T T T] & 0.023 & 0 \\
\hline
\end{tabular}

*Teste de Tukey, controlando erro do tipo I, com significância de 1\% $(p<0.01)$ 
4.5. Modulação de componentes envolvidos na biossíntese da adenosina pela Hidroxiuréia em pacientes com doença falciforme

\subsubsection{Avaliação do Perfil transcricional da ADA em pacientes tratados ou não com Hidroxiuréia}

\subsubsection{Avaliando a pureza das células}

A seleção realizada para obtenção dos monócitos apresentou pureza variável entre 40 e $80 \%$ aproximadamente. Considerando que houve apenas uma passagem na coluna de seleção positiva, justificando assim os baixos níveis de pureza obtidos.

Na figura 8, uma das avaliações de pureza dos monócitos, obtidos por seleção positiva, por seleção positiva de 9 pacientes com Doença Falciforme, por citometria de fluxo.
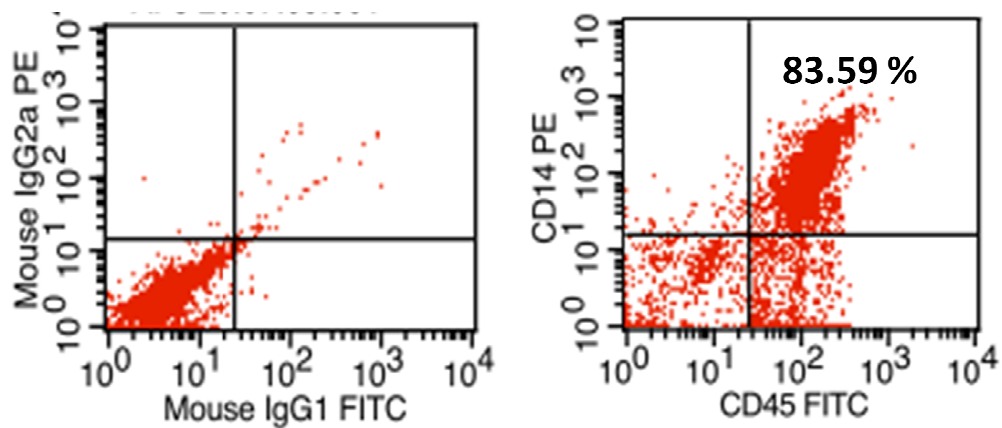

Figura 8. Avaliação por citometria de fluxo da pureza dos monócitos obtidas por seleção positiva. Esquerda: Dot plot do isotipos controle. Direita: Dot plot com $83.59 \%$ (gated). 
A imunofenotipagem revelou um perfil típico de células hematopoéticas; CD45 e CD14. Um total de 10.000 eventos foram registrados correspondentes às células marcadas.

Apenas amostras com pureza acima de $70 \%$ foram utilizadas para avaliar o nível transcricional do gene da enzima ADA

\subsubsection{Avaliação do Perfil Transcricional da ADA (RT-PCR)}

A quantificação da expressão relativa da adenosina deaminase por PCR em tempo real em monócitos de pacientes com anemia falciforme, confirmou os dados obtidos anteriormente por Microarray, pelo Dr. Rodrigo Panepucci em colaboração com o grupo francês de Jaques Elion. Neste estudo 467 genes foram identificados como diferencialmente expressos entre os dois grupos de pacientes tratados ou não; dentre estes 232 genes estavam aumentados no grupo de pacientes tratados, destacando a expressão aumentada em duas vezes do transcrito da ADA nos monócitos destes pacientes (Fold $>1.2 ; \mathrm{P}<0.05$, T-test).

O resultado da validação em amostras adicionais mostrou então que a expressão desta enzima estava realmente aumentada no grupo de pacientes sob o uso da Hidroxiuréia, (obtendo $P=0.03$ Mann-Whitney), como pode ser verificado na figura 9 . 


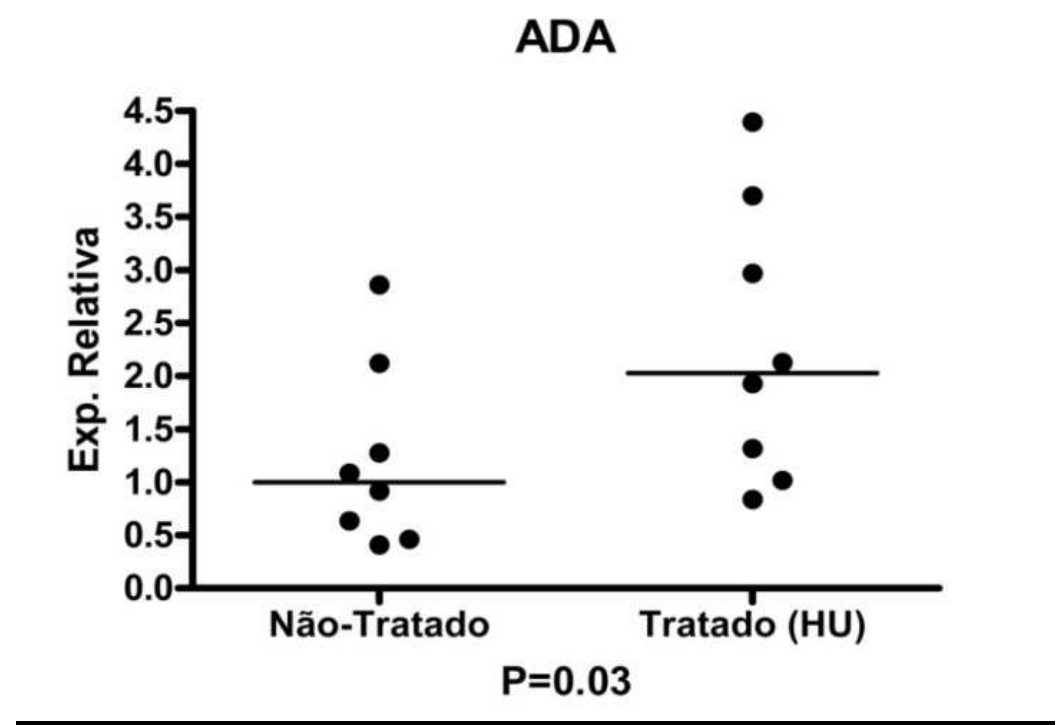

Figura 9. Análise de expressão gênica relativa da adenosina deaminase (ADA), por PCR em Tempo Real. Células mononucleares de pacientes não tratados e tratados com HU foram submetidas à extração de RNA e análise de expressão do gene ADA. A significância estatística foi determinada pelo teste não paramétrico de Mann-Whitney $(P=0.03)$.

4.5.2. Avaliação da modulação da expressão de CD39, CD73 e CD26 em linfócitos e monócitos de paciente falciformes, frente ao tratamento com HU.

Foi realizada a avaliação por citometria de fluxo das células (linfócito e monócito) marcadas com CD39, CD73 e CD26 de 12 pacientes tratados e 21 não tratados e 7 indivíduos controles, mostrou que pacientes sob tratamento apresentavam um aumento da expressão de CD26 em monócitos $(p=0.017)$ e diminuição da expressão de CD39 em linfócitos ( $p=0.043$ ) (Figura 10).

Em linfócitos não houve diferenças significativas de expressão de CD39 e CD73, assim como para os monócitos a diferença de expressão de CD39 também não foi relevante e CD73 não foi detectado (Figura 10). 


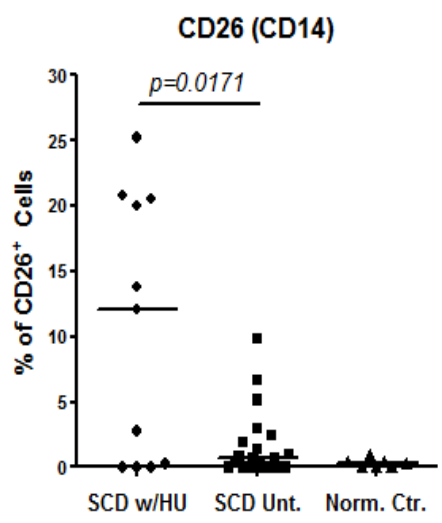

CD26 (CD3)

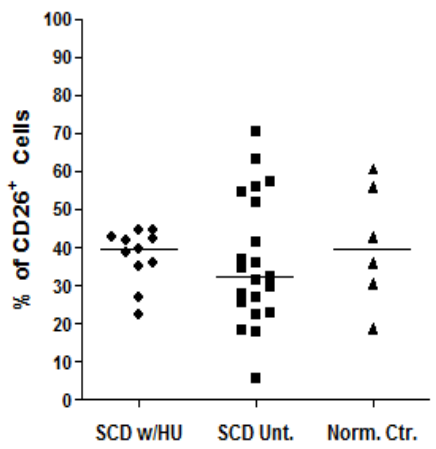

CD73 (CD3)

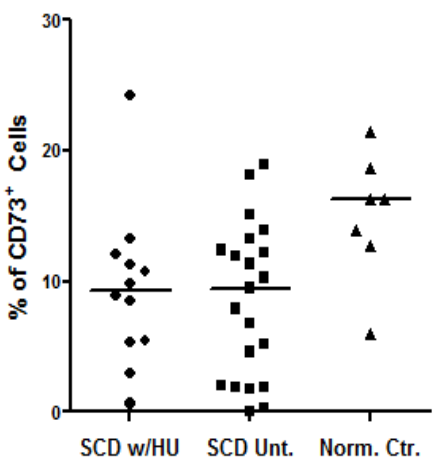

CD39 (CD14)

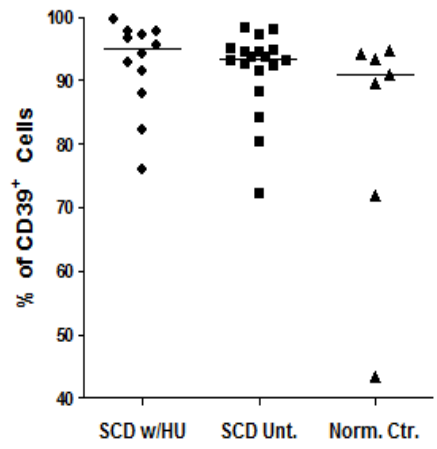

CD39 (CD3)

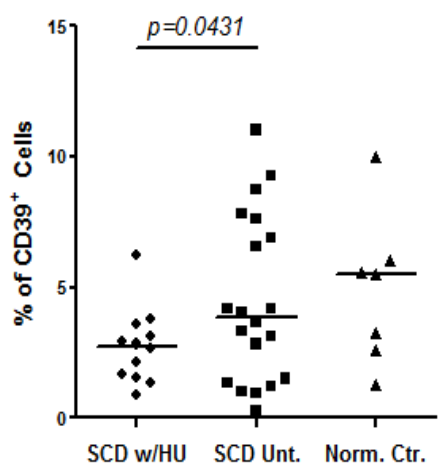

Figura 10. Expressão de CD26, CD39 E CD73 em monócitos e linfócitos por citometria de fluxo em pacientes com doença falciforme sob o uso (ou não) da hidroxiuréia. significância estatística foi determinada pelo teste-T não pareado. 
5. DISCUSSÃAO 


\subsection{Polimorfismo do gene de receptor de adenosina A1}

A presença de receptores de adenosina A1 (ARs A1) foi relatada em diferentes tipos de células humanas importantes na fisiopatologia da asma, incluindo APCs, células epiteliais das vias respiratórias humanas e células da musculatura lisa brônquica, linfócitos, mastócitos, neutrófilos, monócitos, macrófagos, fibroblastos e células endoteliais (CRONSTEIN et al, 1990, 1992;. SALMON \& CRONSTEIN, 1990; MARONE et al, 1992;. SALMON et al, 199.; PEACHELL et al, 1998;. FORSYTHE et al, 1999; PANTHER et al, 2001; McNAMARA et al, 2004;. ETHIER \& MADISON, 2006; CLARK et al, 2007; BROWN et al, 2008). Estes são diferencialmente expressos no pulmão humano (VARANI et al., 2006). Sob condições fisiológicas normais, ARs A1 estão quiescentes, no entanto, são induzidos em condições de estresse, tais como isquemia, e em condições de inflamação, tipificado pelo envolvimento inflamatório das vias aéreas em humanos asmáticos (LAl et al, 2005;. ROGACHEV et al, 2006;. BROWN et al., 2008). Situação esta comum entre os pacientes falciformes.

AR A1 exibe tanto atividade pró e anti-inflamatória em modelos celulares e animais de inflamação (HASKO et al., 2008). No contexto de modelos dirigidos ao estudo da asma humana, no entanto, os estudos sugerem que este receptor tem uma função pró-inflamatórias (POLOSA \& BLACKBURN, 2009).

A ativação do AR A1 nestes diferentes tipos de células induz a liberação de mediadores e citocinas que levam à hiper-reatividade, inflamação e remodelação das vias aéreas. Esta ativação do AR A1 em células epiteliais das vias aéreas, mastócitos, neutrófilos, monócitos, macrófagos e células 
endoteliais induz a liberação de substâncias que causam efeitos celulares próinflamatório que causam a broncoconstrição, edema e a secreção de muco nas vias aéreas que levam a obstrução ao fluxo aéreo na asma (CRONSTEIN et al, 1990, 1992;. SALMON e CRONSTEIN, 1990; SALMON et al, 1993;. FORSYTHE et al, 1999.; WILSON \& e BATRA, 2002; McNAMARA et al, 2004;. ETHIER \& MADISON, 2006, CLARK et al, 2007).

Em neutrófilos humanos, a ativação dos ARs $A 1$ induz a quimiotaxia de neutrófilos, aderência de neutrófilos às células endoteliais ativadas, fagocitose e geração de ânion superóxido (CRONSTEIN et al, 1990, 1992;. SALMON \& CRONSTEIN, 1990). Em culturas de monócitos humanos, o efeito da adenosina sobre receptor A1 é pró-inflamatório, aumenta fagocitose e induz a liberação do fator de crescimento endotelial vascular (SALMON et al, 1993;: CLARK et al, 2007). Além disso, foi relatado que a ativação da A1 ARs em células endoteliais pulmonares humana de artérias induz a liberação de tromboxano, IL-6 (WILSON \& BATRA, 2002) e a expressão do gene 2 MUC (que atua aumentando a produção de muco) em células epiteliais humanas das vias aéreas é aumentada na presença de adenosina (McNAMARA et al., 2004).

Ponnoth et al., 2010 também investigou os efeitos da adenosina na reatividade e inflamação vascular, utilizando camundongos selvagens e nocautes para ADORA 1 sensibilizados com um análogo da adenosina, e observou que os animais selvagens tiveram inflamação tecidual vascular, uma expressão aumentada de ADORA1 e aumento da hiperresponsividade das vias aéreas, em relação aos animais nocaute, indicando que ADORA 1 é responsável pela aumento da hiperresponsividade e aumento da inflamação sistêmica. 
Em modelo com coelho alérgicos, demonstrou-se que o tratamento com um antagonista A1R pode atenuar a inflamação pulmonar, bem como broncoconstrição (NADEEM et al., 2006).

Estudos pré-clínicos mostram que antagonistas A1R poderiam atenuar características da asma, incluindo a inflamação das vias respiratórias, produção de muco e broncoconstrição (RUSSO et al., 2006)

Tomando conhecimento da importância deste gene para sintomatologias pulmonares, comuns em pacientes falciformes, decimos estudar este gene. Analisando o polimorfismo (rs16851030) para o gene ADORA 1, encontramos um aumento da freqüência do alelo $\mathrm{T}$ em pacientes afetados com síndrome torácica aguda, apesar de não termos encontrado associação estatística relevante $(p=0.112)$.

Em concordância com os nossos dados, este mesmo SNP foi estudado por KIM et al., 2009, em 136 pacientes com asma intolerante à aspirina e em 183 indivíduos normais, onde foram encontrado diferenças significativas da freqüências genotípicas do SNP (rs16851030) entre pacientes normais e pacientes com AIA ( $P=0.001)$. Apresentando uma frequencia de homozigotos do alelo mutante $\mathrm{T} / \mathrm{T}$ maior em pacientes com asma aspirina intolerante do que nos pacientes normais $(p=0.001)$, indicando o alelo $T$ como fator de risco forte para asmáticos aspirina intolerantes. Foi avaliado também o papel funcional deste polimorfismo onde mostrou-se que indivíduos com genótipo T/T mostram uma reação mais rápida ao desafio de inalação com aspirina $(p=0.009)$. Ainda não foi esclarecido como uma variante 3 'UTR poderia induzir alterações na resposta brônquica à aspirina; no entanto, uma possibilidade é que a mudança 
do nucleotídeo poderia alterar a estabilidade do mRNA transcrito levando a um aumento de expressão do receptor, influenciando o desenvolvimento da associação positiva a este fenótipo (KIM et al., 2009). E outro estudo, três polimorfismos na região 3'UTR de ADORA1 foram associados a alterações específicas no infarto isquêmico do coração; estes polimorfismos levariam a diferenças estruturais no mRNA (TANG et al., 2007).

Observando a tendência positiva desta associação, podemos sugerir que os pacientes falciforme que apresentam 0 alelo $T$, se tornam mais vulneráveis em situações de stress onde ocorre o aumento dos níveis de adenosina, que sensibilizará os receptores $A 1$, que estarão com sua expressão aumentada pela mutação, consequentemente levará a liberação de citocinas, aumento da hiper-reatividade das vias aéreas, inflamação e remodelação das vias aéreas e até a broncoconstrição. Porém são necessários maiores estudos com este objetivo, inclusive com um maior número amostral.

Analisando os casos de hipertensão pulmonar, a freqüência deste polimorfismo não foi significativamente diferente entre os grupos afetado ou não. A ativação dos receptores pela adenosina, cujos níveis variam em diferentes condições fisiopatológicas, depende da afinidade dos 4 receptores, da densidade, tipo de célula que está expresso e tipo da proteína $G$ envolvida (FREDHOLM et al., 2001). Indicando que este polimorfismo possivelmente não esteja relacionado realmente como hipertensão pulmonar.

O receptor de adenosina também poderia estar envolvido com algumas alterações óssseas. 
A homeostase do osso depende do equilíbrio entre formação óssea pelos osteoblastos e reabsorção óssea pelos osteoclastos, estes processos estão intimamente ligados (CLOHISY, 2007).

Os osteoblastos são as principais células formadoras de ossos, sendo derivados de células tronco mesenquimais (BIANCO \& GEHRON, 2000). Os osteoclastos, que são células gigantes multinucleadas responsáveis pela reabsorção óssea, formadas a partir da fusão dos precursores mielóides dos monócitos e linhagem de macrófagos (MIYAMOTO et al., 2001) sob o controle hormonal sistêmicos e fatores locais produzidos por osteoblastos e células da medula óssea (KATA et al., 2010). Quando este equilíbrio é perturbado em favor da reabsorção óssea o resultado é a destruição patológica do osso, como observado na osteoporose (SCHETT, 2007) ou doenças inflamatórias, tais como a artrite reumatóide (OCHI et al., 2007).

Foi demonstrado que a ativação do receptor de adenosina $\mathrm{A} 1$ é necessária para a formação e função adequada dos osteoclastos in vitro (KARA et al., submitted for publication).

Kara et al., 2010, analisou a densidade mineral óssea em camundongos ovariectomizados, selvagens e nocaute para ADORA 1 e após 5 semanas quando a osteopenia tinha se desenvolvido, exames histológicos dos camundongos mostraram que os animais nocaute apresentavam um aumento significativo do volume ósseo e ausência de reabsorção osteoclástica. Em análise imunohistológica demonstrou que apesar de os osteoclastos estarem presentes em camundongos nocaute, eles foram menores e muitas vezes não associado com o osso. Além disso, a administração do antagonista do receptor 
de adenosina A1 (DPCPX - 1,3-dipropyl-8- cyclopentylxanthine) impediu a indução de perda óssea em modelo ovariectomizados de osteoporose.

Esse resultados sugerem que antagonistas de receptor de adenosina A1 podem representar uma classe promissora de drogas anti-absorvente para o tratamento da osteoporose e outras doenças do osso associada com aumento da atividade dos osteoclastos (KARA et al., 2010).

Apesar da importância deste gene para a reabsorção óssea, não encontramos nos nossos resultados associação significativa para nossos pacientes, apesar de observarmos uma diminuição dos genótipos C/T e T/T entre os afetados $(p=0.698)$.

A adenosina tem um papel importante de sinalização fisiológica no sistema nervoso periférico e central (DUNWIDDIE \& MASINO, 2001). Durante injúria isquêmica e traumática cerebral (BELL et al., 1998; WINN et al., 1979), adenosina é liberada em grandes quantidades e exerce uma influência neuroprotetora em grande parte através do receptor A1 (DE MENDONÇA et al., 1995; PEARSON et al., 2003).

Pela inibição da hiperatividade neural, a adenosina neutraliza a atividade de apreensão e promove a sobrevivência dos neurônios (BIBER et al., 2001).

Foi relatado que a estimulação com IL-6 de astrócitos cultivados de fatias do córtex cerebral de camundongos induz a expressão de mRNA do receptor de adenosina $\mathrm{A} 1$ de forma tempo-dependente, levando a um aumento dos efeitos neuroprotetores da adenosina (BIBER et al., 2001). 
Nos nossos resultados não encontramos diferenças de freqüência genotípicas e alélicas significantes, embora exista um aumento da freqüência dos genótipo $\mathrm{C} / \mathrm{T}$ e $\mathrm{T} / \mathrm{T}$ entre os pacientes afetados $(\mathrm{p}=0.511)$.

A adenosina é conhecida por inibir a liberação de noradrenalina dos nervos simpáticos, através da ativação pré-sináptica dos receptores A1 (RONGEN et al, 1996;. BURNSTOCK, 2006). Existem evidências experimentais para a inibição da noradrenalina mediada pela adenosina lançada em corpos cavernosos, estabelecendo inequivocamente o papel neuromodulador da adenosina na ereção peniana, pelo receptor A1 (PHATARPEKAR et al., 2010).

Em estudos anteriores com animais de múltiplas espécies, incluindo humanos (KILLIC et al., 1994), mostrou-se que a injeção intracavernosa de adenosina resultou em tumescência peniana (CHIANG et al., 1994; YONEZAWA et al., 2002; NOTO et al., 2001).

Já Tostes et al., 2007, mostrou o envolvimento do receptores A1 na modulação da contração neuronal induzida por adenosina. Ambos receptores A2A e A2B não apresentaram nenhum papel na modulação dos neurônios.

Segundo Noto et al., 2001, a teofilina, um antagonista do receptor de adenosina, inibiu tumescência peniana induzida pela adenosina.

Em nossos pacientes não encontramos associação significante deste polimorfismo para priapismo, apesar de notarmos um aumento da freqüência genotípica de $\mathrm{C} / \mathrm{T}$ e $\mathrm{T} / \mathrm{T}$ entre os pacientes afetados em relação aos não afetados $(p=0.793)$. 
São raros os trabalhos realizados com este polimorfismo para que possamos ter uma base de comparação com os nossos resultados, nem mesmo existem certezas a respeito dos efeitos que tal polimorfismo possa causar. Notando-se a necessidade mais estudos com este objetivo. 


\section{2. $\quad$ Polimorfismo do gene de receptor de adenosina A3}

Receptores de adenosina A3 são os mais recentemente descobertos e foram encontrados em alta densidade em eosinófilos (KNIGHT et al, 1997.;KOHNO et al., 1996) e nas vias aéreas (WALKER et al., 1997). Quando ativados, os receptores de adenosina $\mathrm{A} 3$ em eosinófilos humanos mediam a inibição da degranulação e liberação de ânion superóxido (EZEAMUZIE \& PHILIPS, 1999).

Estes receptores também são expressos em neutrófilos humanos (BOUMA et al 1994,;: GESSI et al., 2002) e sua ativação inibe a degranulação dos neutrófilos induzida por endotoxina (GESSI et al., 2002).

Os receptores A3 também têm sido implicados na supressão de liberação de TNF- $\alpha$ induzida por endotoxina de monócitos humanos (LE VRAUX et al., 1993).

Tem sido demonstrado que o mRNA e a proteína do receptor de adenosina A3 são aumentadas em pulmão de asmáticos (WALKER et al., 1997).

Em camundongos deficientes de ADA a expressão de receptores de adenosina A3 foi encontrado em células produtoras de muco nas vias aéreas e o antagonista seletivo de A3 (MRS 1523) inibiu a produção de muco e impediu eosinofilia (YOUNG et al., 2004).

Assim agonistas seletivos para este receptor podem ser valiosos como drogas anti-inflamatórias no tratamento de condições como asma e DPOC, 
onde eosinófilos e neutrófilos ativados desempenham um papel importante (POLOSA, 2002).

Os poucos resultados sobre o papel de receptores A3 na neuroproteção são bastante contraditórios. Foi constatado que a estimulação de receptores $A 3$ pelo agonista seletivo, Cl-IB-MECA, em baixas concentrações, inibe a morte celular, em culturas de células gliais, enquanto que altas concentrações levam a morte celular (ABBRACCHIO et al., 1998; ABBRACCHIO et al., 1997). Portanto, parece que, dependendo das condições experimentais, que ainda não foram bem definidas, o estímulo de $A 3$ exerce efeito neuroprotetor ou neurotóxicos (DE MENDONÇA et al., 2000).

Especula-se que a atenuação de situações de hipóxia e isquemia no sistema nervoso central, pelo menos em parte se dá pelo o receptor A3 (WARDAS, 2002).

Nos nossos resultados não encontramos nenhuma diferenças genotípica e alélica relevantes associadas com nenhuma das características estudadas.Talvez por este SNP estar localizado numa região intrônica não produzindo nenhum efeito funcional que prejudique o funcionamento deste receptor. 


\subsection{Polimorfismo do gene de receptor de adenosina A2B}

A hipóxia é um estímulo importante para a hiper-sensibilização da expressão do receptor A2B e que tem sido mostrado a indução da transcrição deste receptor em células endoteliais (ELTZCHING et al., 2003).

A expressão de receptores $A 2 b$ foi descrita em células epiteliais brônquicas humanas, células musculares lisas, monócitos, células endoteliais e fibroblastos (FEOKTISTOV et al, 2002;. ZHONG et al, 2004, 2005, 2006; RUSSO et al, 2006); macrófagos apresentam um elevado nível de expressão (YANG et al., 2006); mastócitos (HUA et al., 2007; RYZHOV et al., 2008); linfócitos (MIRABET et al., 1999; ECKLE et al., 2008); células dendríticas (NOVITSKIY et al., 2008; BEN ADDI et al., 2008) e neutrófilos (ECKLE et al., 2008).

Vários estudos demonstram os efeitos pró-inflamatórios do estímulo de A2B observados em células de músculo liso brônquico em humanos (ZHONG et al., 2004), células epiteliais brônquicas humanas (ZHONG et al., 2006) e fibroblastos de pulmão humano (ZHONG et al., 2005), que produzem aumento dos níveis de IL-6 (ZHONG et al., 2004; ZHONG et al., 2005) e IL-19 em resposta à ativação (ZHONG et al., 2006). Incluindo a liberação de IL-18 a partir de células HMC-1 (FEOKTISTOV \& BIAGGIONI, 1995); IL-4 e IL-13 (RYZHOV et al., 2004; RYZHOV et al., 2008) de HMC-1 e mastócitos derivados de células de medula óssea do rato e MCP- 1 a partir de células da musculatura lisa brônquica (ZHONG et al., 2003). Todas estas envolvidas nos processos críticos de doenças pulmonares crônicas. 
A ativação dos ARs A2b em HBECs induz a liberação de IL-19, que, por sua vez, induz a liberação de TNF-a de monócitos humanos, o que aumenta a expressão de ARs A2b em HBECs (ZHONG et al., 2006). Em HBSMCs, ativação de A2b ARs induz a expressão e liberação de IL-6 e MCP-1 (ZHONG et al. , 2004).

A IL-6 tem uma função importante na remodelação das vias aéreas através da promoção de hiperplasia de glândulas mucosas, hiperplasia brônquica e hipertrofia muscular, fibrose subepitelial e hiperplasia de miofibroblastos. Além disso, MCP-1, uma quimiocina da classe $\mathrm{C}-\mathrm{C}$, medeia a infiltração e ativação de leucócitos, diferenciação de células $T$ e hiperresponsividade das vias aéreas (ZHONG et al., 2004).

Muitos trabalhos evidenciam os efeitos pró-inflamatórios da ativação do receptor $\mathrm{A} 2 \mathrm{~B}$ na asma e doença pulmonar obstrutiva crônica (DPOC) tanto em roedores e humanos. Evidências in vivo mostram que o antagonismo seletivo dos receptores de adenosina A2B leva à inibição de inflamação e reatividade das vias aéreas induzida por alérgenos ou AMP em modelo murino asmático (MUSTAFA et al., 2007).

Estudos adicionais indicam um papel pró-fibrótico da sinalização A2BR, promovendo a diferenciação de fibroblastos pulmonares humanos (ZHONG et al., 2005), regulando diretamente a produção de moléculas pró-fibróticas de fibronectina nas células epiteliais alveolares (ROMAN et al., 2006).

Nos nossos resultados encontramos valores significativos de freqüência alélica para o SNP 1007 C>T do gene ADORA 2 B, onde o grupo de afetados com síndrome torácica aguda apresentou um aumento da freqüência do alelo $T$ 
( $p=0.032)$ indicando como possível fator de risco para esta característica. A freqüência genotípica já não foi significativa, talvez pelo tamanho da amostragem insuficiente. Para o SNP 968 G>T houve um aumento da freqüência genotípica de $G / T$ ( $p=0.345)$ com aumento na freqüência alélica de $T(p=0.271)$ entre os afetados.

Analisando os pacientes com hipertensão pulmonar, não encontramos freqüências genotípicas e alélicas significantes para o SNP 968 G>T, porém ocorre aumento da freqüência de $G / T, T / T$ e diminuição do genótipo $G / G$ $(p=0.242)$.

Para o SNP 1007 C>T não houve diferenças significativas de freqüência alélica e genotípica para esta característica, mas observamos um aumento do genótipo $T / T$ entre os afetados com hipertensão pulmonar ( $p=0.282)$.

Com relação aos haplótipos encontrados entre os dois SNP no gene ADORA 2B, observamos o aumento da freqüência haplotípica h2 [G-T] e h3 [TT] e diminuição de h1 [G-C]. Os haplótipos h2 [G-T] e h3 [T-T] foram significativamente associados com síndrome torácica aguda sugerindo como fatores de risco $(p<0.01)$. E pacientes com hipertensão pulmonar apresentam uma associação significativa dos h2 [G-T] com fator de risco $(p<0.01)$.

A influência destes polimorfismos presentes no gene do receptor de adenosina A2B mostra que a mutação para o alelo T em ambos SNPs inclusive nos haplótipos, predominam entre os afetados, indicando que estes polimorfismo, mesmo sendo sinônimos, estão produzindo algum efeito diferencial de transcrição do gene, intensificando a função do receptor A2B aumentando seus efeitos pró-inflamatórios sobre as células epiteliais 
brônquicas e fibroblastos do pulmão dos pacientes falciformes, promovendo a remodelação das vias aéreas, com hiperplasia brônquica, fibrose subeptelial, hiperplasia dos miofibroblastos entre outras. Piorando o quadro clínico dos pacientes com doença falciforme.

Receptores de adenosina A2 também foram identificados no corpo cavernoso peniano de humanos (FILIPPI et al., 2000) e cães (NOTO et al., 2001).

Tostes et al., 2007, mostrou que a adenosina tem um efeito relaxante sobre o músculo dos corpos cavernosos mediados pela ativação dos receptores $\mathrm{A} 2 \mathrm{~A}$ e $\mathrm{A} 2 \mathrm{~B}$ em murinos.

Mi et al., 2008 demostrou por PCR em tempo real que a expressão do mRNA de receptor de adenosina predominante em células musculares lisas de camundongos é o A2B.

Em estudos realizados por $\mathrm{Mi}$ et al. 2008, utilizando camundongos deficientes para receptores de adenosina, uma completa ausência de relaxamento mediado pela adenosina foi observada no corpos cavernosos (CC) de camundongos knockout para o receptor A2B, fornecendo fortes evidências de que a adenosina induz relaxamento da CC através de receptores A2B.

Em experimento desenvolvido por Faria et al., 2006, utilizando agonistas e antagonistas de receptores A2 tendo como objetivo caracterizar a mediação dos receptores $\mathrm{A} 2 \mathrm{~A}$ e $\mathrm{A} 2 \mathrm{~B}$ no relaxamento de corpos cavernosos humanos controles e em pacientes com disfunção vasculogênica grave de ereção. Os dados sugeriram que a adenosina regula o tônus da musculatura lisa dos corpos cavernosos por meio da ativação dos receptores A2A e A2B, 
localizados nas fibras musculares lisas e células endoteliais, respectivamente. A disfunção endotelial pode estar correlacionada com uma perda de atividade do receptor de adenosina $\mathrm{A} 2 \mathrm{~B}$ em vasos penianos de homens com disfunção erétil vasculogênica.

Em experimento desenvolvido por Katakoa et al., 2007, com o objetivo de investigar a participação dos receptores de adenosina no relaxamento de corpos cavernosos do pênis de coelhos. O relaxamento foi induzido por ATP (5'-adenosina trifosfato) e foi feita a avaliação da supressão do relaxamento com antagonistas para $\mathrm{A} 2 \mathrm{~A}$ e $\mathrm{A} 2 \mathrm{~B}$; os resultados sugeriram que o relaxamento dos corpos cavernosos em coelhos é provocado diretamente pelo receptor A2B. A figura 11 revisa os mecanismos de sinalização intracelular envolvidos no músculo liso mediado pela adenosina no relaxamento e a ereção peniana.

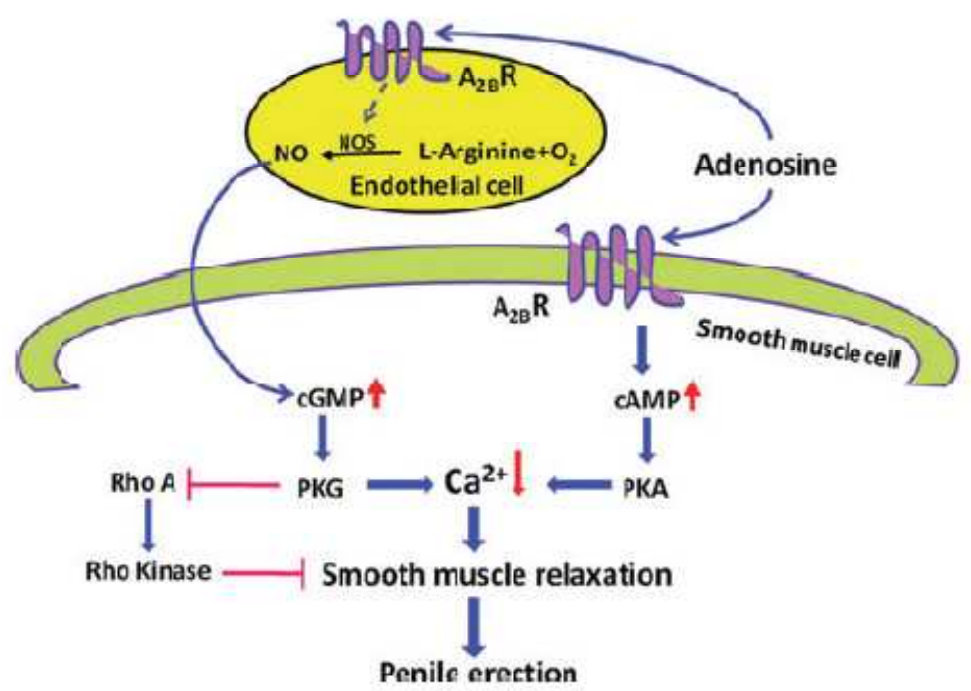

Figura 11. Modelo do papel da adenosina na sinalização intracelular das células de musculatura lisa nos corpos cavernosos do pênis. Adenosina induz síntese tanto de, cGMP e cAMP, em corpos cavernosos.Indução de cAMP é mediada através de receptores $A 2 B$ em células músculo liso. A indução de cGMP pela adenosina é mediado possivelmente pela ativação da síntese de óxido nítrico em células endoteliais através da sinalização de receptores A2B. O óxido nítrico aumentado se difunde pelas células do músculo liso podendo induzir cGMP.Tanto cAMP e cGMP, ativam suas kinases, PKA e PKG, respectivamente, os quais se estiverem bloqueados resultam na diminuição da concentração do cálcio intracelular, contribuindo para o relaxamento do músculo liso. Fonte: PHATARPEKAR et al., 2009. 
Não encontramos em nossos resultados diferenças relevantes das freqüências alélicas e genotípicas associadas ao priapismo. Somente para o SNP $968 G>T$ verifica-se um freqüência aumentada do genótipo $G / G$ e diminuição de $G / T$ entre os afetados $(p=0.773$ ). Já nas análise dos haplótipos formados pelos SNP 968 G>T e 1007 C>T, houve associação do ht1 [G-C] como fator de risco entre os afetados $(p<0.01)$ e como fator protetor $(p<0.01)$. os haplótipos ht2 [G-T] e ht3 [T-T].

A segunda análise haplotípica, com os 3 SNPs encontramos associação significativa $(p<0.01)$ de ht1 [C-G-T], ht3 [C-T-T] e ht4 [T-G-C] entre os afetados para priapismo caracterizando haplótipos de risco e o ht2 [C-G-T] foi associado entre os não afetados, caracterizando-o como fator de proteção $(p<0.01)$.

Pode ser que o alelo $\mathrm{G}$ do SNP $968 \mathrm{G}>\mathrm{T}$, tido como o alelo selvagem, facilita a transcrição normal do DNA, com pleno funcionamento do receptor A2B, quando estimulado, executa a sua função de relaxamento sobre os corpos cavernosos, como vem sido descrito na literatura citada. Já os pacientes não afetados pelo priapismo, parece que o alelo T deste SNP atua como um fator protetor, já que a transcrição deste gene não deve ser perfeita, produzindo um receptor ineficiente para ser sensibilizado pela adenosina e atuar no relaxamento das células do músculos lisos dos CC. A associação dos haplótipos entre estes dois SNPs 968 G>T e 1007 C>T, contribui para estes resultados já que o ht1 [G-C] se apresenta significativamente associado como fator de risco entre os afetados $(p<0.01)$ e os haplótipos ht2 [G-T] e ht3 [T-T]. como fatores protetores $(p<0.01)$. Mostrando portanto que o alelo $G$ do SNP 968 G>T e o alelo C do SNP 1007 C>T contribuem como fatores de risco para priapismo associados como haplótipos. 
Nos últimos anos, vários pesquisadores sugeriram que as moléculas extracelulares de nucleotídeos tais como o ATP podem, através da ligação à família de receptores P2, (BURNSTOCK, 1978; ABBRACCHIO \& BURNSTOCK, 1994) desempenhar um papel importante na diferenciação e função de células (osteoblastos, osteoclastos, condrócitos) encontradas em ossos e cartilagens. (HOEBERTZ et al., 2003; GALLAGHER, 2004; KORKOK et al., 2004). No entanto há muito pouca informação na literatura, no entanto, sobre a expressão dos receptores de adenosina em células ósseas (EVANS et al., 2006).

Tem sido mostrado a existência de receptores $A 2 A$ e A2B em condrócitos articular humano (KOOLPE et al., 1999).

Em estudo desenvolvido por Evans et al., 2006, analisando os níveis de adenosina extracelular de células do estroma da medula óssea humana (BMS) e de uma linhagem de células osteoprogenitoras (HCC1). Investigou-se a expressão e atividade de CD73, receptores de adenosina e medições de AMPc, além dos efeitos de agonistas do receptor de adenosina sobre produção de IL-6, OPG (osteoprotegerina) e a expressão de RANKL. E foram encontrados que as células HCC1 e BMS produzem adenosina e expressam CD73, além de expressarem todos os 4 receptores de adenosina. O receptor A2b mostrou-se funcionalmente dominante em células $\mathrm{HCC} 1$, conforme determinado pela produção de AMPc e na sua estimulação da secreção de IL6. O agonista do receptor de adenosina também inibiu a secreção de OPG, mas não a expressão de mRNA de RANKL. Concluindo que em células HCC1, a adenosina tem uma potente ação estimulante sobre a secreção de IL-6, mas uma ação inibitória sobre a expressão de OPG. Resultando portando na 
estimulação da osteoclastogênese (Figura 12) (SHIN et al., 2004; VERMES et al., 2002; PALMQVIST et al., 2002; KUDO et al., 2007).

Estes dados mostram o papel funcional de adenosina na osteoblastogênese e osteoclastogênese, sendo útil para o desenvolvimento de terapias para doenças como a osteoporose, onde a destruição do osso excede a formação óssea (EVANS et al., 2006).

Observando os nossos dados, encontramos associação significativa da freqüência genotípica para o SNP 968 G>T onde o grupo de pacientes com alterações ósseas apresentam uma diminuição dos genótipos G/T e T/T, indicando o genótipo $\mathrm{G} / \mathrm{G}$ como fator de risco para o desenvolvimento desta patologia $(p=0.0043)$. $O$ alelo $G$ deste polimorfismo, tido como 0 alelo selvagem, provavelmente é o que vem produzindo um receptor $A 2 B$ em perfeitas condições de funcionamento e por isso mesmo se apresenta como fator de risco, visto que este receptor possui um papel importante na diferenciação e funções das células ósseas, sendo predominante em células osteoprogenitoras onde a sua estimulação aumenta a secreção de IL-6 e inibi a secreção de OPG, estimulando desta forma o processo de reabsorção óssea (osteoclastogênese), agravando portanto os quadro de osteoporose e osteopenia nos pacientes falciformes. Já o alelo $T$ se mostra como fator de proteção, possivelmente por produzir um receptor incapaz de gerar resposta de reabsorção óssea.

Para o SNP 1007 C>T também é possível notar uma diferença relevante das freqüências, onde existe um aumento dos genótipos $\mathrm{C} / \mathrm{C}$ e $\mathrm{C} / \mathrm{T}$ e diminuição do genótipo T/T entre o grupo com alterações ósseas $(p=0.013)$, 
indicando o alelo $\mathrm{C}$ para um risco aumentado para o desenvolvimento de alterações ósseas. Sugerimos, portanto que o alelo $\mathrm{C}$, tido como o mais comum na população, gera uma proteína perfeitamente funcional, exercendo seu papel na osteoclastogênese, atuando para a piora do quadro clínico dos pacientes falciformes e o alelo $T$ possivelmente produz uma proteína não funcional, ou uma expressão de mRNA diminuída ou menos estável, exercendo um papel de proteção contra as alterações ósseas.

$\mathrm{Na}$ análise haplotípica entre os dois SNPs do gene ADORA 2B, houve associação significativa do ht1 [G-C] entre os pacientes afetados, mostrado como fator de risco para alterações ósseas $(p<0.01)$ e o ht2 [G-T] e ht3 [T-T] como fatores de proteção $(p<0.01)$, contribuindo para os nossos resultados de associação de cada SNP individualmente. 


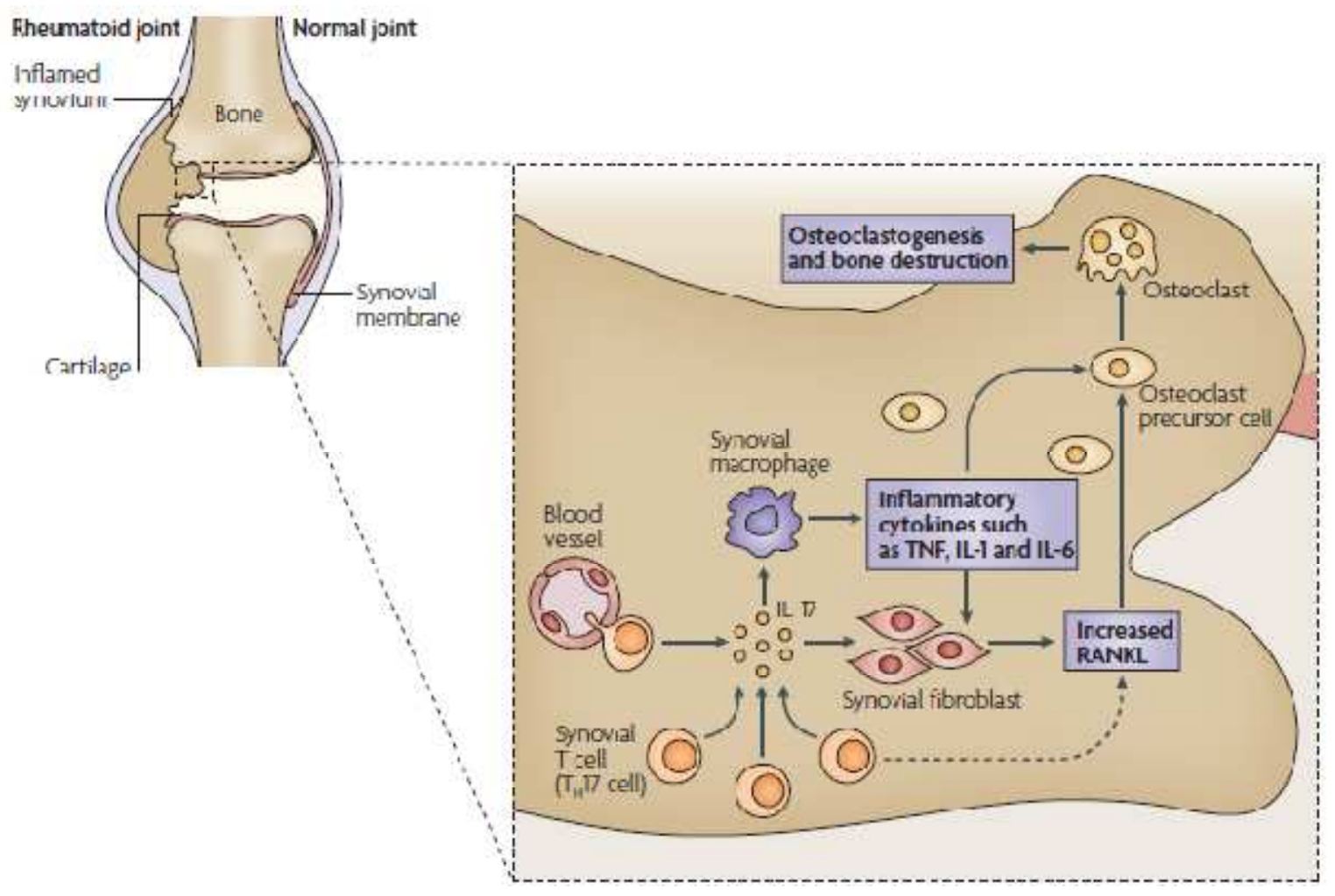

Figura 12. Como células $T$ induzem osteoclastogêne na artrite autoimune. $\mathrm{Na}$ artrite reumatóide, citocinas inflamatórias invadem e destroem os ossos; isto é mediado pelos osteoclastos que são induzidos por RANKL (receptor ativador do fator nucelar $\mathrm{k} \beta$ ). Células do sinóvio inclui macrófagos e fibroblastos em adição as células dendríticas, células plasmáticas, células endoteliais e células T infiltrantes. Embora a infiltração de células T CD4 seja uma marca da patogênese da artrite, a ligação entre as células $T$ e a ativação de osteoclastos mediando a reabsorção ósseas tem sido recentemente mostrado: que as células $T$ helper produtoras de IL-17 é o único subconjunto osteoclastogênico caracterizado há tempos. Estas células não produzem IFNy, que suprime a sinalização de RANKL, mas secretam uma enorme quantidade de IL-17 induz RANKL em fibroblastos sinoviais. IL-17 também estimula a inflamação local e ativa os macrófagos por meio da sinalização com TNF, IL-1 e IL-6. Estas citocinas ativam a osteoclastogêneses agindo diretamente em células precursoras de osteoclasto ou induzindo RANKL em fibroblastos sinoviais. As células T helper produtoras de IL-17 também expressam RANKL em sua membrana, o qual contribui para o aumento da osteoclastogênese.Fonte: TAKAYANAGI, 2007

Os receptores A2b são amplamente distribuídos no cérebro e estão localizadas predominantemente em astrócitos (WILLIANS, 1995), e também podem regular a função da glia (FEOKTISTOV \& BIAGGIONI, 1997; PEAKMAN \& HILL, 1994; PORTER e McCARTHY, 1995; PILITSIS \& KIMELBERG , 1998). A adenosina age como um neuromodulador endógeno na neuroproteção 
cerebral através deste receptor (RUDOLPHI \& SCHUBERT, 1996). Algumas evidências também indicam uma ação neuroprotetora da citocina IL-6 (LODDICK et al 1998;. MATSUDA et al 1996;. TOULMOND et al 1992). Ambos os compostos são sintetizadas e liberadas no cérebro em condições patológicas, como a isquemia (LODDICK et al., 1998;. RUDOLPHI \& SHUBERT, 1996).

O aumento das concentrações locais de adenosina pode diminuir a inflamação através da estimulação do receptor de adenosina do tipo 2 no endotélio vascular, que resultam em uma inibição da secreção de citocinas inflamatórias (CRONSTEIN et al. 1996; EIGLER et al. , 1997). A ativação de receptores $\mathrm{A} 2 \mathrm{~B}$ pode reduzir a expressão do complexo de histocompatibilidade de classe I,I (MHC II) na microglia (FIEBICH et al. 1996; XAUS et al. 1999) e aumento dos níveis de mRNA de IL-6 em astrócitos (FIEBICH et al, 1996); estas citocinas inibem a produção de TNF-a (BENVENISTE et al. 1995).

Isto implica que a estimulação de receptores A2B pela alta concentração de adenosina acumulando em condições patológicas poderia, pelo menos parcialmente ser instrumental para o grande aumento na síntese de IL-6 no cérebro observada sob estas condições (BIBER et al., 2001).

Em estudo desenvolvido por Rossi et a., 2003, com pacientes com doença de Alzheimer (DA) mostrou que através de uma droga não esteróide anti-inflamatória, atenua significativamente os processos que conduzem a patologia associada a DA através da ativação de receptores de adenosina A2B.

Em experimento realizado por Kusano et al., 2009, em camundongos nocaute para A2A e outros para A2B com o objetivo de avaliar a vasodilatação 
durante a hipotensão arterial, expondo-os a curtos (2-5 minutos) períodos de hipotensão arterial, demonstrou por métodos farmacológicos, que a vasodilatação ocorre por meio de ambos os receptores $A 2 A$ e A2B. E mostrou também que na ausência do receptor A2A (camundongos nocaute), ocorre um aumento da expressão de $\mathrm{A} 2 \mathrm{~B}$ e que são capazes de participar da vasodilatação.

Observando os nossos resultados não encontramos diferenças significativas de freqüência alélica e genotípica dos nossos polimorfismos em estudo deste gene ADORA 2B, porém existe um aumento da freqüência genotípica de $G / G$ entre o grupo afetado e aumento dos genótipos $G / T$ e $T / T$ entre os não afetados, para o SNP $968 \mathrm{G}>\mathrm{T},(p=0.126)$.

Para o SNP 1007 C>T, existe um aumento da freqüência genotípica de $\mathrm{C} / \mathrm{C}$ e $\mathrm{C} / \mathrm{T}$ e diminuição de $\mathrm{T} / \mathrm{T}$ entre os afetados, porém a diferença entre os dois grupos não foi significativa $(p=0.192)$.

Acreditamos que estes valores de $p$ poderiam ser significativos se tivéssemos uma número amostral maior, pois nota-se uma tendência do valor para a associação positiva destes dois polimorfismo no gene ADORA 2B com estenose/AVC, indicando o alelo G do SNP 968 G>T e o alelo C do SNP 1007 C>T como fatores de risco.

Sugerimos que possivelmente o alelo G do SNP 968 ( $G>T)$ e o alelo C do SNP 1007 (C>T), traduzam um proteína de receptor A2B com uma afinidade menor pela adenosina, desta forma não exercendo totalmente sua função de ativação do receptor $\mathrm{A} 2 \mathrm{~B}$ e conseqüente neuroproteção. 
$\mathrm{Na}$ associação haplotípica entre os SNPs do gene ADORA 2B, entre os pacientes afetados encontramos associação significativa do ht1 [G-C], sendo indicativo de haplótipo de risco $(p<0.01)$ e ht3 $[T-T]$ está associado com fator de proteção $(p<0.01)$. Estes dados estão em concordância e colaboram com os achados anteriores individuais.

Na segunda análise haplotípica com os 3 SNP do gene ADORA 1 e ADORA 2B, encontramos o ht1 [C-G-C] e ht6 [T-G-T] significativamente associados $(p<0.01)$ como fator de risco entre os afetados e h2 [C-G-T], h4 [CT-T] e h5 [T-G-C] foram significativamente associados entre os não afetados indicando-os como fator de proteção $(p<0.01)$.

Estes dois SNPs encontrados no gene ADORA 2B, de uma forma geral para todas as características analisadas houve uma redução da heterozigosidade tanto entre o grupo controle quanto no grupo dos afetados, com conseqüente não adesão ao equilíbrio de Hardy-Weinberg, indicando que forças evolutivas vêm atuando sobre estes polimorfismos, e provavelmente a deriva genética seja a responsável por este processo, levando em consideração que a mutação no gene da hemoglobina $S$ é de origem africana, inserido por meio do tráfico de escravos para o Brasil, gerando um população não representativa das freqüências alélicas esperadas na população original africana.

Destacamos que os polimorfismo de receptores de adenosina ainda são muito pouco estudados, tornando este presente estudo pioneiro na associação de tais SNPs com as diversas patologias apresentadas pelos doentes falciformes. 


\subsection{Polimorfismo do gene da adenosina deaminase}

Considerando a importância da enzima adenosina deaminase em muitas funções fisiológicas na participação da manutenção do equilíbrio nucleotídeo trifosfato no metabolismo energético celular (HUNSUCKER et al., 2005). Onde a adenosina é metabolizada em iosina. E levando em consideração que alterações na equilíbrio desta reação têm sido relatadas em várias patologias já descritas até o momento, é que resolvemos estudar este gene em pacientes com doença falciforme, que desenvolvem situações de hipóxia (onde existe um aumento da adenosina) provocadas pelo processo de vaso-oclusão característico desta doença.

Com relação ao desequilíbrio desta reação em casos de problemas pulmonares tem sido relatado inúmeros estudos sob este aspecto.

Como exemplo podemos citar o trabalho desenvolvido por Blackburn et al., 2000 onde foi mostrado que camundongos deficientes de ADA apresentaram sinais de hipertensão pulmonar crônica em associação com elevados níveis de adenosina.

Interessantemente, a hiperresponsividade das vias aéreas assim como a inflamação e a fibrose pulmonar, comuns entre pacientes falciformes (CABOOT \& ALLEN, 2008; LEONG \& STARK, 1998), são também características de camundongos parcialmente deficientes na enzima ADA (CHUNN, 2001; CHUNN 2005).

Estudos recentes mostram que a atenuação da sinalização da adenosina poderá reverter fenótipos pulmonares graves em camundongos com deficiência de ADA, sugerindo que a crônica elevação de adenosina podem 
afetar as vias de sinalização que medeiam doenças pulmonares crônicas (CHUNN et al., 2005; SUN et al., 2005).

O polimorfismo funcional mais freqüente da ADA é causado por uma transição G->A no nucleotídeo 22 (codificação DNA 22G $\rightarrow$ A) e que não por acaso foi objeto de nosso estudo. Esta transição leva à substituição de asparagina para ácido aspártico no códon 8 (proteína Asp8Asn) da proteína ADA (Hirschhorn et al., 1994). Indivíduos com genótipo G/A apresentam 2030\% menor atividade enzimática nas hemácias e leucócitos que os indivíduos com o genótipo G/G (BATTISTUZZI et al., 1981).

As seguintes freqüências genotípicas esperadas na população caucasianos saudáveis está distribuída da seguinte forma: G/G 88-92\%; G/A 12-08 \%; A/A < 1\% (SPENCER et al., 1968; PERSICO et al., 2000).

No nosso estudo não encontramos nenhuma difereça relevante do SNP G22A do gene ADA com relação a sídrome torácica aguda $(p=1.0)$ nem para hipertensão pulmonar $(p=1.0)$. Talvez por ser um polimorfismo como pouca ou quase nenhuma representatatividade de homozigotos recessivos, não caracterizando bem a influência deste SNP sobre tais patologias.

Outros estudos também vem relacionando a importância desta enzima como relação ao priapismo. Os autores identificaram episódios freqüentes de priapismo em camundongos deficientes $A D A$ mantidos vivos por suplementação enzimática. Os níveis elevados de adenosina (comparado a camundongos controle) foram identificados como causa dos episódios não apenas nos camundongos deficientes de $A D A$ como também em camundongos modelos de anemia falciforme, onde o priapismo é comum (Ml et al., 2008) 
Analisando o SNP G22A no gene ADA, no nosso estudo, não identificamos diferenças significativas para o teste de associação com priapismo, porém houve uma aumento da freqüência genotípica de G/A e diminuição do genótipo $G / G$ entre ao afetados ( $p=0.602$ ). Sabendo que este genótipo G/A produz uma enzima menos eficiente, por conseqüência, os níveis de adenosina estarão aumentados. Concordando com os estudos descritos que mostram o aumento de adenosina como causa dos episódios freqüentes de priapismo e camundongo deficientes de ADA e em camundongos modelos de anemia falciforme (Ml et al., 2008).

Defeitos esqueléticos foram relatados como uma característica comum de humanos deficientes de ADA (RATECH et al., 1998; CHAKRAVARTI et al., 1991). O fenótipo ósseo descrito é consistente com a hipótese de que o metabolismo das purinas alteradas prejudica a gênese, proliferação e atividade dos osteoblastos e osteoclastos (HASKO et al., 2007; EVANS et al., 2006; SHIMEGI, 1998; ORRISS et al., 2006).

SAUER et al., 2009, mostrou que metabolismo da ADA representa um fator modulatório ósseo crucial nas remodelação e atividades celulares, onde camundongos deficientes de ADA desenvolvem alterações de propriedades estruturais e mecânicas do osso, mostrando um redução da capacidade de suporte in vitro e hematopoiese in vivo.

ATP extracelular também se encontram aumentados durante fratura óssea e reparação óssea (BUCHOLZ et al., 2004).

Apesar de não termos encontramos diferenças significativas nos nossos resultados deste polimorfismo com as alterações ósseas, no entanto notamos 
um aumento da frequencia genotípica $G / A$ e diminuiçao do genótipo $G / G$ entre os pacientes afetados $(p=0.525)$. Podemos sugerir então que este aumento da frequência genotípica $\mathrm{G} / \mathrm{A}$, que diminui a atividade da enzima ADA (BATTISTUZZI et al., 1981), aumentando os níveis de adenosina, que como foi mostrado pela literatura já citada acima, pode prejudicar a osteoblastogênese e osteoclastogênese, contribuindo para o agravamento dessas alterações ósseas observadas no pacientes falciforme em nosso estudo.

Além dos efeitos vasomotores direto sobre os vasos sanguíneos, a adenosina pode modular a atividade do sistema nervoso simpático (SNS).

Durante injúria isquêmica e traumática cerebral (BELL et al., 1998; WINN et al., 1979), adenosina é liberada em grandes quantidades e exerce uma influência neuroprotetora em grande parte através da A1 receptor (DE MENDONÇA et al., 1995; PEARSON et al., 2003)

No cérebro as mudanças na concentrações de adenosina e seus metabólitos, incluindo inosina e hipoxantina, durante isquemia depende da atividade de ADA (KOBAYASHI et al., 1998).

Este polimorfismo G22A do gene ADA, tem sido associados ao autismo (BOTTINI et al., 2001), leve retardo mental (SACCUCCI et al., 2006) e maior duração e intensidade do sono profundo em indivíduos saudáveis, (RÉTEY et al., 2005) reforçando as conseqüências funcionais deste polimorfismo na neuromodulação mediada pela adenosina.

Dutra et al., 2010, investigando este polimorfismo em 152 indivíduos esquizofrênicos e 111 controles saudáveis, observou-se uma diminuição significativa do genótipo G/A em pacientes esquizofrênicos (G/G 95,4\% , 4,6\% 
G/A e $0 \% A / A)$ em relação ao controle $(13-11,7 \%, p=0,032$, OR= 2,6 (GG $88,3 \%, 11,7 \%$ GA e $0 \%$ AA)). Sugerindo que o genótipo G/A, associada com a baixa atividade de ADA, e potencialmente com níveis aumentados de adenosina é menos freqüente em pacientes esquizofrênicos.

Stubbs e et al., 1982 relataram diminuição da atividade de ADA no soro crianças com autismo em comparação a controles normais.

No entanto Zoruglu, et al., 2004 testou atividade de ADA eritrocitária em crianças com autismo e em controles por sexo e idade comparável e não encontraram diferenças na atividade da $\operatorname{ADA}(p=0,52)$.

Em estudo desenvolvido por Durmaz et al., 2008, com 40 pacientes com hemorragia subaracnóide (HSA) e 10 controle, observou um aumento do nível de atividade de ADA em pacientes com HSA.

Os nossos dados mostraram que existe um aumento da freqüência genotípica G/G do SNP do gene ADA entre os pacientes afetados para estenose/AVC e uma diminuição do genótipo $G / A$, porém a diferença não foi significativa $(p=0.469)$. Levando em consideração os dados da literatura, nossos resultados estão de acordo com a maioria, que mostra a atividade diminuída da enzima ADA em pacientes que possuem o genótipo G/A, elevando os níveis de adenosina. Portando os nossos pacientes apresentaram maior chance de desenvolver esta patologia provavelmente devido à atividade aumentada de ADA, diminuindo os níveis de adenosina, que no caso desta patologia funciona como neuroproterora.

A freqüência dos genótipos na nossa população $(94,72$ \% do genótipo G/G, 5,28 \% do genótipo G/A e $0 \%$ de $A / A$ ) esta de acordo com a população 
caucasiana descrita por SPENCER et al., 1968; PERSICO et al., 2000 e por Dutra et al., 2010 em pacientes esquizofrênicos numa população brasileira.

O tamanho amostral do nosso estudo é considerado por ter um poder limitado de detecção de variantes causais para estudos genéticos, portanto sugerimos que mais estudos devam ser realizados com esses mesmos polimorfismos em um número muito maior de pacientes. Além disso faz-se necessária uma definição melhor dos fenótipos, com ajuda de exames diagnósticos mais precisos, aplicação de questionário ao paciente e maior supervisão médica na orientação dos casos clínicos. 


\subsection{Modulação dos componentes envolvidos na síntese e degradação da adenosina pela hidroxiuréia em pacientes falciformes.}

Em condições fisiológicas a adenosina é derivado do AMP intracelular. AMP intracelular é derivado da clivagem da adenosina difosfato (ADP) e adenosina trifosfato (ATP) durante o ciclo de geração de energia e, portanto, desfosforilação da AMP a adenosina é considerada a última etapa do enzimática cadeia (FREDHOLM et al., 2001).

Durante a hipóxia ou isquemia, a quebra do ATP se acelera, e refosforilação de adenosina por adenosina quinase é inibida, resultando em uma imediata e dramática aumento da concentração de adenosina extracelular (GORLACH, 2005; LASLEY et al., 1999), aumentando assim estimulação dos receptores de adenosina.

Adenosina é gerada extracelularmente pela degradação de nucleotídeos adenina. A ectonucleotidase tais como CD39 hidrolisa ATP e ADP em AMP. CD73 catalisa defosforilação de AMP a adenosina (PHATARPEKAR et al., 2009) (Figura 13). 


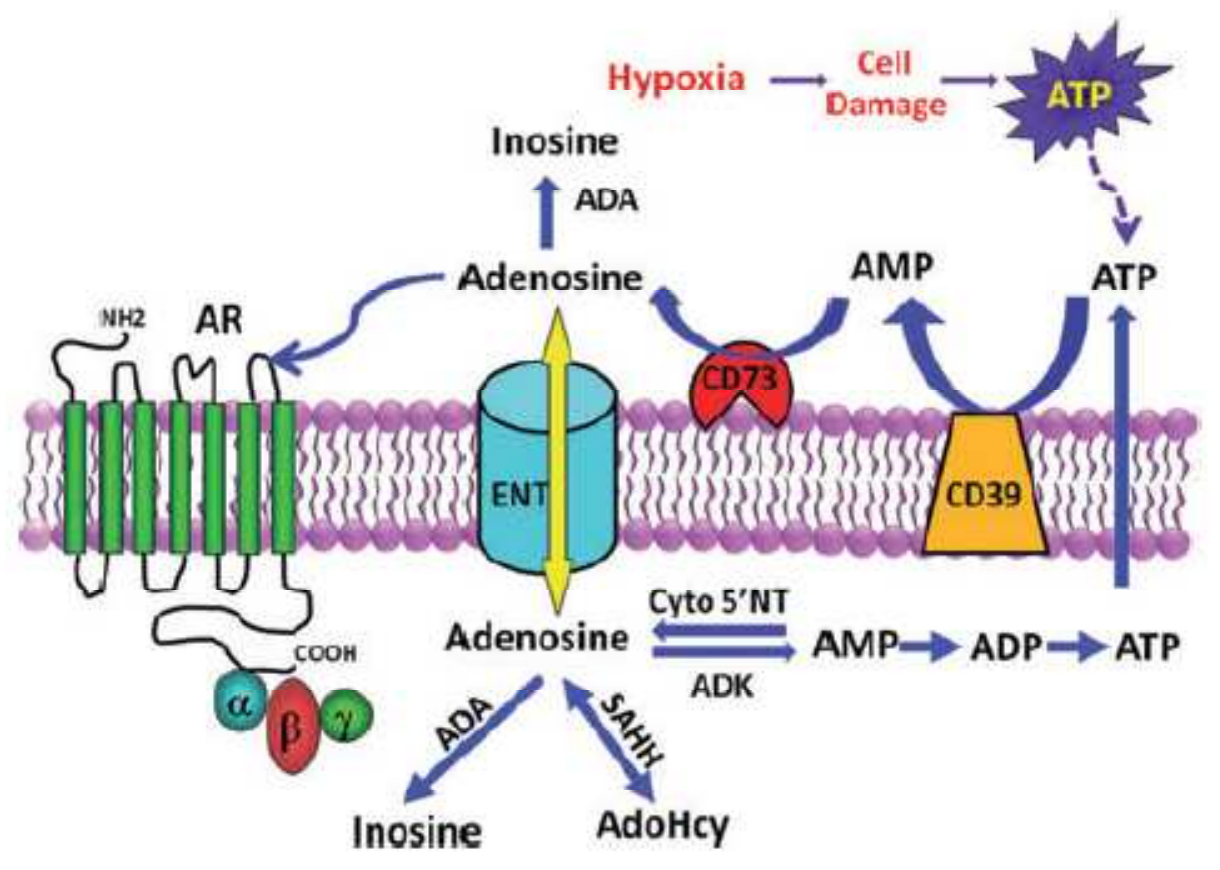

Figura 13. Metabolismo da adenosina. Adenosina é formada pela degradação do nucleotídeo adenina, intra e extracelular. Intracelularmente, a adenosina é formada predominantemente pela defosforilaçao de AMP (adenosina monofosfato) por 5'nucleotidase, mas hidrólise de AdoHCy (s-adenosil-homocisteína) por SAHH (s-adenosil-homocisteína- hidrolase) também contribui. Dentro da célula, adenosina é catabolizada por duas enzimas, ADK (adenosina kinase) e ADA (adenosina deaminase). ADLK fosforila adenosina em AMP. ADA catalisa a conversão irreversível de adenosina a iosina. Adenosina também é gerada extracelularmente pela degradação de nucleotídeos adenina. A ectonucleotidase tais como CD39 hidrolisa ATP e ADP em AMP. CD73 catalisa defosforilação de AMP a adenosina. Adenosina extracelular é degradada em iosina por ADA extracelular. A homeostase de adenosina é mantida pelo transporte bi-direcional através do equilíbrio de transportadores nucleosideos (ENT) na membrana plasmática na direção da concentração do gradiente. A molécula CD26 não aparece na figura, mas, ancora a ADA na membrana externamente, catalizando a conversão da adenosina em inosina localmente. Fonte: PHATARPEKAR et al., 2009. 


\section{ELTZSHIG}

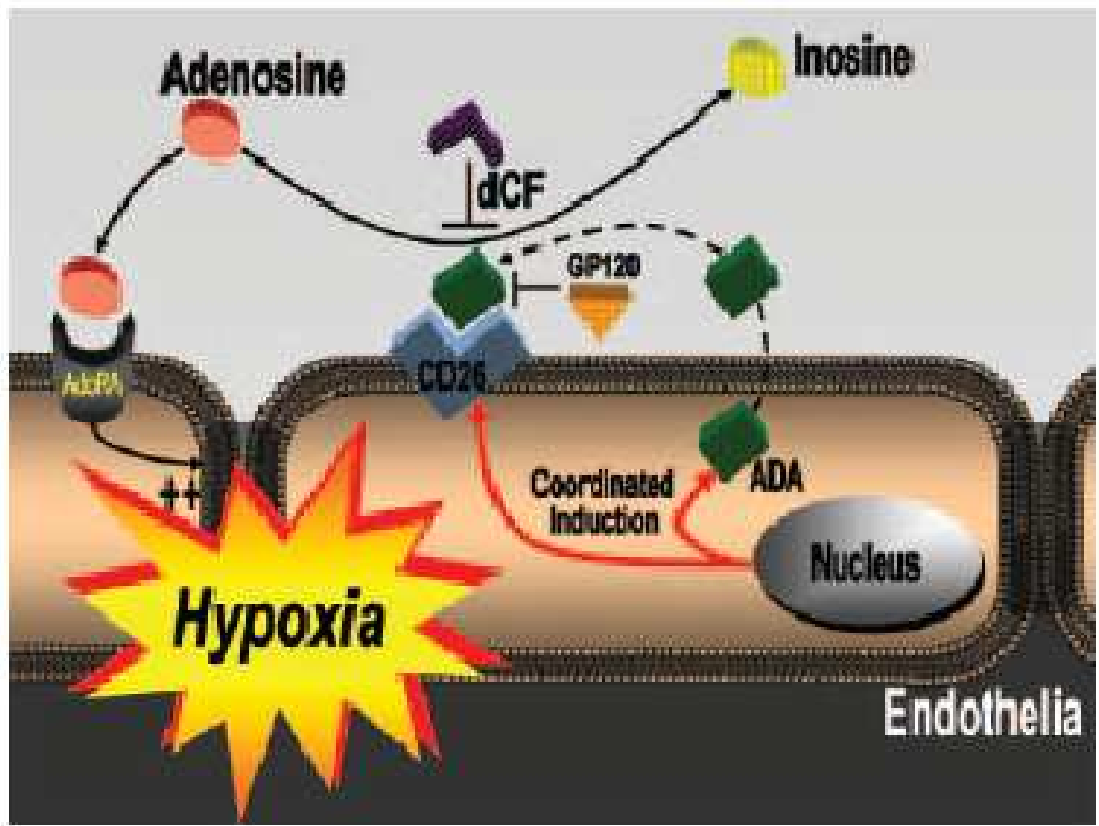

ELTZSHIG

Sabendo que eficácia da HU foi inicialmente atribuída à estimulação

farmacológica de hemoglobina fetal $(\mathrm{HbF})$, mas o fato de que benefícios clínicos ocorram antes do aumento da HbF (BRIDGES et al., 1996), e que não implica necessariamente na melhora clínica dos pacientes. Além de diversos estudos mostrando que esta droga pode também atuar através de outros mecanismos (ROTTER et al., 2005). Entre tais mecanismos adicionais, uma redução da adesão de células falciformes às células do endotélio, PTS ou laminina (BRIDGES et al., 1996; ADRAGNA et al., 1994; HILLERY et al., 2000) e uma redução significativa de a4ß1 e CD36, receptores de adesão em reticulócitos falciformes (STYLES et al., 1997), entre outros. E levando em consideração a melhora clínica da terapia de HU reduz COV dolorosos em pacientes com anemia falciforme (assim como a síndrome torácica aguda e necessidades de transfusão), foi atribuído em parte a uma redução da 
expressão de moléculas de adesão na superfície celular de reticulócitos e hemácias ( $\alpha 4 \beta 1$, CD36, ICAM-4) e leucócitos (OKPALA et al., 2002).

Com essa informações sobre a modulação da HU sobre a expressão de moléculas de adesão em células sanguíneas, além do estudo descrito anteriormente utilizando microarrays, identificando níveis de expressão reduzidos da enzima Adenosina Deaminase (ADA) em monócitos de pacientes com AF tratados por $\mathrm{HU}$, decidimos confirmar esses dados em amostras adicionais, avaliando o perfil transcricional da ADA e verificamos que realmente os pacientes tratados com HU apresentaram uma expressão aumentada em relação aos não tratados $(p=0.03)$. A confirmação deste resultado mostra que realmente podem existir outras explicações para a atuação da $\mathrm{HU}$ e seus benefícios sobre os efeitos agravantes da doença falciforme.

Em um segundo experimento observamos também que a expressão de CD39 estava diminuída em linfócitos $(p=0.043)$ e a expressão CD26 ( $p=0.017)$ estava aumentada em monócitos de pacientes tratados com a hidroxiuréia.

Como conseqüência, destes dois resultados ocorreria uma diminuição na síntese local de adenosina e, simultaneamente, uma maior degradação desta com conseqüente redução de seus níveis e seus efeitos agravantes para os doentes falciformes. 
6. CONCLUSÕES 


\section{Conclusões}

Os resultados indicam um potencial mecanismo adicional de ação da HU, mediado pelo aumento da expressão de CD26 e ADA nos monócitos e diminuição da expressão de CD39 em linfócitos.

$>0$ alelo $\mathrm{T}+1007 \mathrm{C}>\mathrm{T}$ está associado como fator de risco para o desenvolvimento de STA e os genótipos $\mathrm{C} / \mathrm{C}$ e $\mathrm{C} / \mathrm{T}$ como fatores de risco para alterações ósseas. O genótipo + $968 \mathrm{G} / \mathrm{G}$ está associado como fator de risco para alterações ósseas e os genótipos $+968 \mathrm{G} / \mathrm{T}$ e T/T como fatores protetores.

> Concordando com dados da literatura, encontramos uma maior freqüência do alelo T do SNP rs1685103 no gene ADORA1, entre os pacientes com STA, porém este resultado não foi estatisticamente significante, sendo necessário um maior número amostral.

> Em concordância com a literatura,o G/A do SNP G22A se apresenta com uma freqüência aumentada entre os afetados com priapismo, alterações ósseas e para estenose/AVC ocorre um aumento da freqüência de $\mathrm{G} / \mathrm{G}$.

> Houve associação dos haplótipos formados entre os SNPs 968 G>T e $1007 \mathrm{C}>\mathrm{T}$, h2 [G-T] e h3 [T-T] como fatores de risco para STA $(p<0.01)$. Em pacientes com hipertensão pulmonar houve associação de h2 [G-T] com fator de risco $(p<0.01)$. Pacientes com priapismo foram associados com ht1 [G-C] como fator de risco e como fatores protetores os ht2 [G-T] e ht3 [T-T]. Pacientes com alterações ósseas possuem o ht1 [G-C] como haplótipo de risco e ht2 [G-T] e ht3 [T-T] como fatores de proteção, e por último houve associação dos haplótipos ht1 [G-C] como fator de risco para estenose/AVC e ht3 [T-T] como fator de proteção. Em segunda análise haplotípica, com os 3 SNPs encontramos associação de ht1 [C-G-T], ht3 [C-T-T] e ht4 [T-G-C] como fatores de risco entre os afetados para priapismo e o ht2 [C-G-T] foi caracterizando como fator de proteção. Encontramos também o ht1 [C-G-C] e h6 [T-G-T] significativamente associados como fator de risco entre os afetados com estenose/AVC e h2 [C-G-T], h4 [C-T-T] e h5 [T-G-C] foram associados como fator de proteção. 


\section{Perspectivas}

Este estudo foi pioneiro na tentativa de avaliar a possível influência da adenosina e seus receptores sob a fisiopatologia da doença falciforme, abrindo portas para novos estudos neste sentido.Os resultados aqui encontrados poderão contribuir para o melhor entendimento de influências genéticas sob a grande variabilidade de manifestações clínicas que caracterizam a doença falciforme, além de informações adicionais sobre a atuação da hidroxiuréia. Possibilitando assim um manejo racional, identificando pacientes de risco e até mesmo à determinação de alvos para o desenvolvimento de novos fármacos. 
7. REFER ENNCIAS BIBLIOGRÁAICAS 
Abbracchio, M. P., et al. "The A3 adenosine receptor mediates cell spreading, reorganization of actin cytoskeleton, and distribution of Bcl-XL: studies in human astroglioma cells." Biochem.Biophys.Res.Commun. 241.2 (1997): 297-304.

Adair, T. H. "Growth regulation of the vascular system: an emerging role for adenosine." Am.J.Physiol Regul.Integr.Comp Physiol 289.2 (2005): R283-R296.

Adams, R. J. "Big strokes in small persons." Arch.Neurol. 64.11 (2007): 156774.

Adams, R. J., et al. "Stroke prevention trial in sickle cell anemia." Control Clin.Trials 19.1 (1998): 110-29.

Adams, R. J., et al. "Prevention of a first stroke by transfusions in children with sickle cell anemia and abnormal results on transcranial Doppler ultrasonography." N.Engl.J.Med. 339.1 (1998): 5-11.

Adekile, A. D., et al. "Avascular necrosis of the hip in children with sickle cell disease and high $\mathrm{Hb} F$ : magnetic resonance imaging findings and influence of alpha-thalassemia trait." Acta Haematol. 105.1 (2001): 2731.

Adorno, E. V., et al. "Hemoglobinopathies in newborns from Salvador, Bahia, Northeast Brazil." Cad.Saude Publica 21.1 (2005): 292-98.

Adragna, N. C., P. Fonseca, and P. K. Lauf. "Hydroxyurea affects cell morphology, cation transport, and red blood cell adhesion in cultured vascular endothelial cells." Blood 83.2 (1994): 553-60.

Assis, A., et al. "Effect of cytokines and chemokines on sickle neutrophil adhesion to fibronectin." Acta Haematol. 113.2 (2005): 130-36.

Ataga, K. I., et al. "Pulmonary hypertension in patients with sickle cell disease: a longitudinal study." Br.J.Haematol. 134.1 (2006): 109-15.

Ataga, K. I., et al. "Pulmonary hypertension in sickle cell disease." Am.J.Med. 117.9 (2004): 665-69.

Barlow-Stewartand, K. and L. Burnett. "Ethical considerations in the use of DNA for the diagnosis of diseases." Clin.Biochem.Rev. 27.1 (2006): 53-61. 
Barnett, C. F., P. Y. Hsue, and R. F. Machado. "Pulmonary hypertension: an increasingly recognized complication of hereditary hemolytic anemias and HIV infection." JAMA 299.3 (2008): 324-31.

Battistuzzi, G., et al. "Activity of adenosine deaminase allelic forms in intact erythrocytes and in lymphocytes." Ann.Hum.Genet. 45.Pt 1 (1981): 1519.

Behdad,A., et al. "Vascular smooth muscle cell expression of ectonucleotidase CD39 (ENTPD1) is required for neointimal formation in mice". Purinergic.Signal., (2009) 5, 335-342.

Belardinelli, L., J. Linden, and R. M. Berne. "The cardiac effects of adenosine." Prog.Cardiovasc.Dis. 32.1 (1989): 73-97.

Belcher, J. D., et al. "Activated monocytes in sickle cell disease: potential role in the activation of vascular endothelium and vaso-occlusion." Blood 96.7 (2000): 2451-59.

Bell, M. J., et al. "Interstitial adenosine, inosine, and hypoxanthine are increased after experimental traumatic brain injury in the rat." J.Neurotrauma 15.3 (1998): 163-70.

Ben, Addi A., et al. "Modulation of murine dendritic cell function by adenine nucleotides and adenosine: involvement of the $\mathrm{A}(2 \mathrm{~B})$ receptor." Eur.J.Immunol. 38.6 (2008): 1610-20.

Benveniste, E. N., L. P. Tang, and R. M. Law. "Differential regulation of astrocyte TNF-alpha expression by the cytokines TGF-beta, IL-6 and IL10." Int.J.Dev.Neurosci. 13.3-4 (1995): 341-49.

Bernaudin, F. and S. Verlhac. "[Stroke prevention in sickle-cell disease: results, hurdles and future perspectives]." Bull.Acad.Natl.Med. 192.7 (2008): 1383-93.

Berry, P. A., et al. "Hepatic dysfunction in sickle cell disease: a new system of classification based on global assessment." Clin.Gastroenterol.Hepatol. 5.12 (2007): 1469-76.

Bianco, P. and Robey P. Gehron. "Marrow stromal stem cells." J.Clin.Invest 105.12 (2000): 1663-68.

Biber, K., et al. "Interleukin-6 enhances expression of adenosine A(1) receptor mRNA and signaling in cultured rat cortical astrocytes and brain slices." Neuropsychopharmacology 24.1 (2001): 86-96. 
Bjorck, T., L. E. Gustafsson, and S. E. Dahlen. "Isolated bronchi from asthmatics are hyperresponsive to adenosine, which apparently acts indirectly by liberation of leukotrienes and histamine." Am.Rev.Respir.Dis. 145.5 (1992): 1087-91.

Blackburn, M. R., et al. "Adenosine mediates IL-13-induced inflammation and remodeling in the lung and interacts in an IL-13-adenosine amplification pathway." J.Clin.Invest 112.3 (2003): 332-44.

Blackburn, M. R., et al. "Metabolic consequences of adenosine deaminase deficiency in mice are associated with defects in alveogenesis, pulmonary inflammation, and airway obstruction." J.Exp.Med. 192.2 (2000): 159-70.

Bottini, N., et al. "Autism: evidence of association with adenosine deaminase genetic polymorphism." Neurogenetics. 3.2 (2001): 111-13.

Bottini, N., et al. "Adaptation to past malarial endemia and susceptibility to common diseases in modern populations: a study of adenosine deaminase and MN blood group genetic polymorphisms." Am.J.Phys.Anthropol. 128.1 (2005): 194-98.

Bouma, M. G., et al. "Differential regulatory effects of adenosine on cytokine release by activated human monocytes." J.Immunol. 153.9 (1994): 415968.

Bridges, K. R., et al. "A multiparameter analysis of sickle erythrocytes in patients undergoing hydroxyurea therapy." Blood 88.12 (1996): 4701-10.

Brinker, M. R., et al. "Bone mineral density of the lumbar spine and proximal femur is decreased in children with sickle cell anemia." Am.J.Orthop.(Belle.Mead NJ) 27.1 (1998): 43-49.

Brittain, J. E. and L. V. Parise. "The alpha4beta1 integrin in sickle cell disease." Transfus.Clin.Biol. 15.1-2 (2008): 19-22.

Brown, R. A., et al. "Elevated expression of adenosine A1 receptor in bronchial biopsy specimens from asthmatic subjects." Eur.Respir.J. 31.2 (2008): 311-19.

Buchanan, G. R., et al. "Sickle cell disease." Hematology.Am.Soc.Hematol.Educ.Program. (2004): 35-47.

Burnett, A. L. "Erectile dysfunction." J.Urol. 175.3 Pt 2 (2006): S25-S31.

Burnstock, G. "Historical review: ATP as a neurotransmitter." $\underline{\text { Trends }}$ Pharmacol.Sci. 27.3 (2006): 166-76. 
Caboot, J. B. and J. L. Allen. "Pulmonary complications of sickle cell disease in children." Curr.Opin.Pediatr. 20.3 (2008): 279-87.

Canalli, A. A., et al. "Granulocytic adhesive interactions and their role in sickle cell vaso-occlusion." Hematology. 10.5 (2005): 419-25.

Canalli, A. A., et al. "Increased adhesive properties of neutrophils in sickle cell disease may be reversed by pharmacological nitric oxide donation." Haematologica 93.4 (2008): 605-09.

Castro, O., et al. "The acute chest syndrome in sickle cell disease: incidence and risk factors. The Cooperative Study of Sickle Cell Disease." Blood 84.2 (1994): 643-49.

Castro, O., M. Hoque, and B. D. Brown. "Pulmonary hypertension in sickle cell disease: cardiac catheterization results and survival." Blood 101.4 (2003): 1257-61.

Castro, O., F. A. Lombardo, and V. R. Gordeuk. "The celestial fire of conscience." N.Engl.J.Med. 353.12 (2005): 1301-02.

Chakravarti, V. S., et al. "Chondroosseous dysplasia in severe combined immunodeficiency due to adenosine deaminase deficiency (chondroosseous dysplasia in ADA deficiency SCID)." Pediatr.Radiol. 21.6 (1991): 447-48.

Charache, S., et al. "Hydroxyurea and sickle cell anemia. Clinical utility of a myelosuppressive "switching" agent. The Multicenter Study of Hydroxyurea in Sickle Cell Anemia." Medicine (Baltimore) 75.6 (1996): 300-26.

Charache, S., et al. "Effect of hydroxyurea on the frequency of painful crises in sickle cell anemia. Investigators of the Multicenter Study of Hydroxyurea in Sickle Cell Anemia." N.Engl.J.Med. 332.20 (1995): 1317-22.

Chiang, P. H., et al. "Adenosine modulation of neurotransmission in penile erection." Br.J.Clin.Pharmacol. 38.4 (1994): 357-62.

Chomczynski, P. and N. Sacchi. "Single-step method of RNA isolation by acid guanidinium thiocyanate-phenol-chloroform extraction." Anal.Biochem. 162.1 (1987): 156-59.

Chui, D. H. and G. J. Dover. "Sickle cell disease: no longer a single gene disorder." Curr.Opin.Pediatr. 13.1 (2001): 22-27.

Chunn, J. L., et al. "Adenosine-dependent pulmonary fibrosis in adenosine deaminase-deficient mice." J.Immunol. 175.3 (2005): 1937-46. 
Chunn, J. L., et al. "Adenosine-dependent airway inflammation and hyperresponsiveness in partially adenosine deaminase-deficient mice." J.Immunol. 167.8 (2001): 4676-85.

Churchill, P. C. "Renal effects of 2-chloroadenosine and their antagonism by aminophylline in anesthetized rats." J.Pharmacol.Exp.Ther. 222.2 (1982): 319-23.

Claster, S. and E. P. Vichinsky. "Managing sickle cell disease." BMJ 327.7424 (2003): 1151-55.

Clohisy, D. R. "Could apoptosis be responsible for localized imbalances in bone cell homeostasis?" J.Lab Clin.Med. 134.3 (1999): 190-91.

Conran, N., et al. "Leukocyte numbers correlate with plasma levels of granulocyte-macrophage colony-stimulating factor in sickle cell disease." Ann.Hematol. 86.4 (2007): 255-61.

Creary, M., D. Williamson, and R. Kulkarni. "Sickle cell disease: current activities, public health implications, and future directions." J.Womens Health (Larchmt.) 16.5 (2007): 575-82.

Cronstein, B. N., et al. "The adenosine/neutrophil paradox resolved: human neutrophils possess both $A 1$ and $A 2$ receptors that promote chemotaxis and inhibit O2 generation, respectively." J.Clin.Invest 85.4 (1990): 115057.

Cronstein, B. N., et al. "Neutrophil adherence to endothelium is enhanced via adenosine A1 receptors and inhibited via adenosine A2 receptors." J.Immunol. 148.7 (1992): 2201-06.

Cummings, S. R., et al. "Epidemiology of osteoporosis and osteoporotic fractures." Epidemiol.Rev. 7 (1985): 178-208.

Dai, Y., et al. "Adenosine signaling, priapism and novel therapies." J.Sex Med. 6 Suppl 3 (2009): 292-301.

Davies, S. C. and A. Gilmore. "The role of hydroxyurea in the management of sickle cell disease." Blood Rev. 17.2 (2003): 99-109.

de, Mendonca A., A. M. Sebastiao, and J. A. Ribeiro. "Inhibition of NMDA receptor-mediated currents in isolated rat hippocampal neurones by adenosine A1 receptor activation." Neuroreport 6.8 (1995): 1097-100.

Di Nuzzo, D. V. and S. F. Fonseca. "[Sickle cell disease and infection]." J.Pediatr.(Rio J.) 80.5 (2004): 347-54. 
Dong,R.P., et al. "Characterization of adenosine deaminase binding to human CD26 on T cells and its biologic role in immune response". J.Immunol., (1996) 156, 1349-1355.

Dover, G. J., et al. "Hydroxyurea induction of hemoglobin $\mathrm{F}$ production in sickle cell disease: relationship between cytotoxicity and $\mathrm{F}$ cell production." Blood 67.3 (1986): 735-38.

Driscoll, M. C., et al. "Stroke risk in siblings with sickle cell anemia." Blood 101.6 (2003): 2401-04.

Dunwiddie, T. V. and S. A. Masino. "The role and regulation of adenosine in the central nervous system." Annu.Rev.Neurosci. 24 (2001): 31-55.

Durmaz, R., et al. "Nitric oxide level and adenosine deaminase activity in cerebrospinal fluid of patients with subarachnoid hemorrhage." Turk.Neurosurg. 18.2 (2008): 157-64.

Dutra, G. P., et al. "Lower frequency of the low activity adenosine deaminase allelic variant (ADA1*2) in schizophrenic patients." Rev.Bras.Psiquiatr. 32.3 (2010): 275-78.

Eckle, T., et al. "A2B adenosine receptor dampens hypoxia-induced vascular leak." Blood 111.4 (2008): 2024-35.

Eckle, T., et al. "A2B adenosine receptor signaling attenuates acute lung injury by enhancing alveolar fluid clearance in mice." J.Clin.Invest 118.10 (2008): 3301-15.

Eigler, A., et al. "Endogenous adenosine curtails lipopolysaccharide-stimulated tumour necrosis factor synthesis." Scand.J.Immunol. 45.2 (1997): 13239.

Elliott, L., et al. "Genetic polymorphisms associated with priapism in sickle cell disease." Br.J.Haematol. 137.3 (2007): 262-67.

Eltzschig,H.K.,et al. "Coordinated adenine nucleotide phosphohydrolysis and nucleoside signaling in posthypoxic endothelium: role of ectonucleotidases and adenosine A2B receptors". J.Exp.Med., (2003) 198, 783-796. 
Evans, B. A., et al. "Human osteoblast precursors produce extracellular adenosine, which modulates their secretion of IL-6 and osteoprotegerin." J.Bone Miner.Res. 21.2 (2006): 228-36.

Ewing, B. and P. Green. "Base-calling of automated sequencer traces using phred. II. Error probabilities." Genome Res. 8.3 (1998): 186-94.

Ewing, B., et al. "Base-calling of automated sequencer traces using phred. I. Accuracy assessment." Genome Res. 8.3 (1998): 175-85.

Ezeamuzie, C. I. and E. Philips. "Adenosine A3 receptors on human eosinophils mediate inhibition of degranulation and superoxide anion release." Br.J.Pharmacol. 127.1 (1999): 188-94.

Faria, M., et al. "Corpus cavernosum from men with vasculogenic impotence is partially resistant to adenosine relaxation due to endothelial $A(2 B)$ receptor dysfunction." J.Pharmacol.Exp.Ther. 319.1 (2006): 405-13.

Feoktistov, I. and I. Biaggioni. "Adenosine A2b receptors evoke interleukin-8 secretion in human mast cells. An enprofylline-sensitive mechanism with implications for asthma." J.Clin.Invest 96.4 (1995): 1979-86.

Feoktistov, I., et al. "Differential expression of adenosine receptors in human endothelial cells: role of $\mathrm{A} 2 \mathrm{~B}$ receptors in angiogenic factor regulation." Circ.Res. 90.5 (2002): 531-38.

Feoktistov, I., et al. "Hypoxia modulates adenosine receptors in human endothelial and smooth muscle cells toward an A2B angiogenic phenotype." Hypertension 44.5 (2004): 649-54.

Fiebich, B. L., et al. "Adenosine A2b receptors mediate an increase in interleukin (IL)- 6 mRNA and IL-6 protein synthesis in human astroglioma cells." J.Neurochem. 66.4 (1996): 1426-31.

Filippi, S., et al. "Functional adenosine receptors in human corpora cavernosa." Int.J.Androl 23.4 (2000): 210-17.

Forsythe, P., et al. "Adenosine induces histamine release from human bronchoalveolar lavage mast cells." Clin.Sci.(Lond) 96.4 (1999): 349-55.

Fowler, J. E., Jr., et al. "Priapism associated with the sickle cell hemoglobinopathies: prevalence, natural history and sequelae." J.Urol. 145.1 (1991): 65-68.

Franco,R.,et al. "Enzymatic and extraenzymatic role of ecto-adenosine deaminase in lymphocytes". Immunol.Rev., (1998) 161, 27-42. 
Fredholm, B. B. and T. V. Dunwiddie. "How does adenosine inhibit transmitter release?" Trends Pharmacol.Sci. 9.4 (1988): 130-34.

Fredholm, B. B., et al. "International Union of Pharmacology. XXV. Nomenclature and classification of adenosine receptors." Pharmacol.Rev. 53.4 (2001): 527-52.

Fredholm, B. B., et al. "Comparison of the potency of adenosine as an agonist at human adenosine receptors expressed in Chinese hamster ovary cells." Biochem.Pharmacol. 61.4 (2001): 443-48.

Frenette, P. S. "Sickle cell vasoocclusion: heterotypic, multicellular aggregations driven by leukocyte adhesion." Microcirculation. 11.2 (2004): 167-77.

Frenette, P. S. and G. F. Atweh. "Sickle cell disease: old discoveries, new concepts, and future promise." J.Clin.Invest 117.4 (2007): 850-58.

Frenette, P. S., et al. "Susceptibility to infection and altered hematopoiesis in mice deficient in both P- and E-selectins." Cell 84.4 (1996): 563-74.

Gallagher, J. A. "ATP P2 receptors and regulation of bone effector cells." J.Musculoskelet.Neuronal.Interact. 4.2 (2004): 125-27.

Gessi, S., et al. "A(3) adenosine receptors in human neutrophils and promyelocytic HL60 cells: a pharmacological and biochemical study." Mol.Pharmacol. 61.2 (2002): 415-24.

Gill, F. M., et al. "Clinical events in the first decade in a cohort of infants with sickle cell disease. Cooperative Study of Sickle Cell Disease." Blood 86.2 (1995): 776-83.

Gilroy, D. W., et al. "Inflammatory resolution: new opportunities for drug discovery." Nat.Rev.Drug Discov. 3.5 (2004): 401-16.

Gladwin, M. T., et al. "Pulmonary hypertension as a risk factor for death in patients with sickle cell disease." N.Engl.J.Med. 350.9 (2004): 886-95.

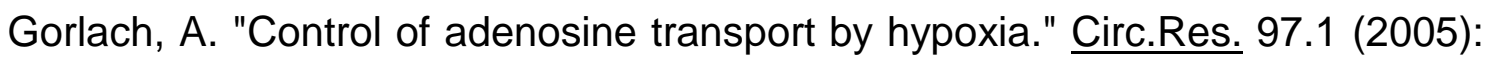
1-3.

Grant, M. B., et al. "Proliferation, migration, and ERK activation in human retinal endothelial cells through A(2B) adenosine receptor stimulation." Invest Ophthalmol.Vis.Sci. 42.9 (2001): 2068-73.

Gupta, R. and A. D. Adekile. "MRI follow-up and natural history of avascular necrosis of the femoral head in Kuwaiti children with sickle cell disease." J.Pediatr.Hematol.Oncol. 26.6 (2004): 351-53. 
Hankey, G. J. and J. W. Eikelboom. "Homocysteine and stroke." Curr.Opin.Neurol. 14.1 (2001): 95-102.

Hasko, G., et al. "A(2B) adenosine receptors in immunity and inflammation." Trends Immunol. 30.6 (2009): 263-70.

Hasko, G., et al. "Adenosine receptors: therapeutic aspects for inflammatory and immune diseases." Nat.Rev.Drug Discov. 7.9 (2008): 759-70.

Hasko, G., et al. "Shaping of monocyte and macrophage function by adenosine receptors." Pharmacol.Ther. 113.2 (2007): 264-75.

Hebbel, R. P., R. S. Schwartz, and N. Mohandas. "The adhesive sickle erythrocyte: cause and consequence of abnormal interactions with endothelium, monocytes/macrophages and model membranes." Clin.Haematol. 14.1 (1985): 141-61.

Hillery, C. A., et al. "Hydroxyurea therapy decreases the in vitro adhesion of sickle erythrocytes to thrombospondin and laminin." Br.J.Haematol. 109.2 (2000): 322-27.

Hirschhorn, R., et al. "Adenosine deaminase deficiency: frequency and comparative pathology in autosomally recessive severe combined immunodeficiency." Clin.Immunol.Immunopathol. 14.1 (1979): 107-20.

Hirschhorn, R., D. R. Yang, and A. Israni. "An Asp8Asn substitution results in the adenosine deaminase (ADA) genetic polymorphism (ADA 2 allozyme): occurrence on different chromosomal backgrounds and apparent intragenic crossover." Ann.Hum.Genet. 58.Pt 1 (1994): 1-9.

Hoebertz, A., T. R. Arnett, and G. Burnstock. "Regulation of bone resorption and formation by purines and pyrimidines." Trends Pharmacol.Sci. 24.6 (2003): 290-97.

Hofstra, T. C., et al. "Sickle erythrocytes adhere to polymorphonuclear neutrophils and activate the neutrophil respiratory burst." Blood 87.10 (1996): 4440-47.

Hua, X., et al. "Enhanced mast cell activation in mice deficient in the A2b adenosine receptor." J.Exp.Med. 204.1 (2007): 117-28.

Huang, S., et al. "Role of A2a extracellular adenosine receptor-mediated signaling in adenosine-mediated inhibition of T-cell activation and expansion." Blood 90.4 (1997): 1600-10. 
Hunsucker, S. A., B. S. Mitchell, and J. Spychala. "The 5'-nucleotidases as regulators of nucleotide and drug metabolism." Pharmacol.Ther. 107.1 (2005): 1-30.

Inwald, D. P., et al. "Platelet and leucocyte activation in childhood sickle cell disease: association with nocturnal hypoxaemia." Br.J.Haematol. 111.2 (2000): 474-81.

Jean-Baptiste, G. and Ceulaer K. De. "Osteoarticular disorders of haematological origin." Baillieres Best.Pract.Res.Clin.Rheumatol. 14.2 (2000): 307-23.

Johnson, S. M., et al. "5'-Nucleotidase as a marker of both general and local inflammation in rheumatoid arthritis patients." Rheumatology.(Oxford) 38.5 (1999): 391-96.

Kameoka,J., et al. "Direct association of adenosine deaminase with a $\mathrm{T}$ cell activation antigen, CD26". Science, (1993) 261, 466-469.

Kara, F. M., et al. "Adenosine A1 receptors (A1Rs) play a critical role in osteoclast formation and function." FASEB J. 24.7 (2010): 2325-33.

Kato, G. J., O. C. Onyekwere, and M. T. Gladwin. "Pulmonary hypertension in sickle cell disease: relevance to children." Pediatr.Hematol.Oncol. 24.3 (2007): 159-70.

Kim, S. H., et al. "Adenosine deaminase and adenosine receptor polymorphisms in aspirin-intolerant asthma." Respir.Med. 103.3 (2009): 356-63.

Knight, D., et al. "Adenosine A3 receptor stimulation inhibits migration of human eosinophils." J.Leukoc.Biol. 62.4 (1997): 465-68.

Kobayashi, T., T. Yamada, and Y. Okada. "The levels of adenosine and its metabolites in the guinea pig and rat brain during complete ischemia-in vivo study." Brain Res. 787.2 (1998): 211-19.

Kohno, Y., et al. "Activation of $A 3$ adenosine receptors on human eosinophils elevates intracellular calcium." Blood 88.9 (1996): 3569-74.

Koolpe, M., D. Pearson, and H. P. Benton. "Expression of both P1 and P2 purine receptor genes by human articular chondrocytes and profile of ligand-mediated prostaglandin E2 release." Arthritis Rheum. 42.2 (1999): 258-67. 
Korcok, J., et al. "Extracellular nucleotides act through P2X7 receptors to activate NF-kappaB in osteoclasts." J.Bone Miner.Res. 19.4 (2004): 64251.

Koshiba, M., et al. "Memory of extracellular adenosine A2A purinergic receptormediated signaling in murine T cells." J.Biol.Chem. 272.41 (1997): 25881-89.

Koumbourlis, A. C., et al. "Prevalence and reversibility of lower airway obstruction in children with sickle cell disease." J.Pediatr. 138.2 (2001): 188-92.

Kudo, O., et al. "Interleukin-6 and interleukin-11 support human osteoclast formation by a RANKL-independent mechanism." Bone 32.1 (2003): 1-7.

Kusano, Y., et al. "Role of adenosine A2 receptors in regulation of cerebral blood flow during induced hypotension." J.Cereb.Blood Flow Metab 30.4 (2010): 808-15.

Lasley, R. D., et al. "Evidence that cytosolic and ecto 5'-nucleotidases contribute equally to increased interstitial adenosine concentration during porcine myocardial ischemia." Basic Res.Cardiol. 94.3 (1999): 199-207.

Le, Vraux, V, et al. "Inhibition of human monocyte TNF production by adenosine receptor agonists." Life Sci. 52.24 (1993): 1917-24.

Lee, S. P., et al. "Biologically active CD40 ligand is elevated in sickle cell anemia: potential role for platelet-mediated inflammation." Arterioscler.Thromb.Vasc.Biol. 26.7 (2006): 1626-31.

Lennon, P. F., et al. "Neutrophil-derived 5'-adenosine monophosphate promotes endothelial barrier function via CD73-mediated conversion to adenosine and endothelial A2B receptor activation." J.Exp.Med. 188.8 (1998): 143343.

Leong, C. S. and P. Stark. "Thoracic manifestations of sickle cell disease." J.Thorac.Imaging 13.2 (1998): 128-34.

Lima, C. S., et al. "Risk factors for conjunctival and retinal vessel alterations in sickle cell disease." Acta Ophthalmol.Scand. 84.2 (2006): 234-41.

Linden, J. "Adenosine in tissue protection and tissue regeneration." Mol.Pharmacol. 67.5 (2005): 1385-87.

Loddick, S. A., A. V. Turnbull, and N. J. Rothwell. "Cerebral interleukin-6 is neuroprotective during permanent focal cerebral ischemia in the rat." J.Cereb.Blood Flow Metab 18.2 (1998): 176-79. 
Lonergan, G. J., D. B. Cline, and S. L. Abbondanzo. "Sickle cell anemia." Radiographics 21.4 (2001): 971-94.

Lum, A. F., et al. "Inflammatory potential of neutrophils detected in sickle cell disease." Am.J.Hematol. 76.2 (2004): 126-33.

MacDermot, K. D., et al. "Short stature/short limb skeletal dysplasia with severe combined immunodeficiency and bowing of the femora: report of two patients and review." J.Med.Genet. 28.1 (1991): 10-17.

Machado, R. F. and M. T. Gladwin. "Chronic sickle cell lung disease: new insights into the diagnosis, pathogenesis and treatment of pulmonary hypertension." Br.J.Haematol. 129.4 (2005): 449-64.

Madigan, C. and P. Malik. "Pathophysiology and therapy for haemoglobinopathies. Part I: sickle cell disease." Expert.Rev.Mol.Med. 8.9 (2006): 1-23.

Makis, A. C., E. C. Hatzimichael, and K. L. Bourantas. "The role of cytokines in sickle cell disease." Ann.Hematol. 79.8 (2000): 407-13.

Marone, G., et al. "Adenosine receptors on human leukocytes. IV. Characterization of an A1/Ri receptor." Int.J.Clin.Lab Res. 22.4 (1992): 235-42.

Matsuda, S., et al. "Interleukin-6 prevents ischemia-induced learning disability and neuronal and synaptic loss in gerbils." Neurosci.Lett. 204.1-2 (1996): 109-12.

McNamara, N., et al. "Adenosine up-regulation of the mucin gene, MUC2, in asthma." FASEB J. 18.14 (2004): 1770-72.

McPherson, J. A., et al. "Adenosine $\mathrm{A}(2 \mathrm{~A})$ receptor stimulation reduces inflammation and neointimal growth in a murine carotid ligation model." Arterioscler.Thromb.Vasc.Biol. 21.5 (2001): 791-96.

$\mathrm{Mi}, \mathrm{T}$., et al. "Excess adenosine in murine penile erectile tissues contributes to priapism via A2B adenosine receptor signaling." J.Clin.Invest 118.4 (2008): 1491-501.

Miller, S. T., et al. "Silent infarction as a risk factor for overt stroke in children with sickle cell anemia: a report from the Cooperative Study of Sickle Cell Disease." J.Pediatr. 139.3 (2001): 385-90.

Milner, P. F., et al. "Sickle cell disease as a cause of osteonecrosis of the femoral head." N.Engl.J.Med. 325.21 (1991): 1476-81. 
Mirabet, M., et al. "Expression of A2B adenosine receptors in human lymphocytes: their role in T cell activation." J.Cell Sci. 112 ( Pt 4) (1999): 491-502.

Miyamoto, T., et al. "Bifurcation of osteoclasts and dendritic cells from common progenitors." Blood 98.8 (2001): 2544-54.

Moffatt, M. F., et al. "Genetic variants regulating ORMDL3 expression contribute to the risk of childhood asthma." Nature 448.7152 (2007): 470-73.

Morimoto,C. \& Schlossman,S.F. "The structure and function of CD26 in the Tcell immune response". Immunol.Rev., (1998) 161, 55-70.

Morris, C. R., et al. "Dysregulated arginine metabolism, hemolysis-associated pulmonary hypertension, and mortality in sickle cell disease." JAMA 294.1 (2005): 81-90.

Mota, E. G., et al. "Evaluation of diametral tensile strength and Knoop microhardness of five nanofilled composites in dentin and enamel shades." Stomatologija. 8.3 (2006): 67-69.

Mustafa, S. J., et al. "Effect of a specific and selective A(2B) adenosine receptor antagonist on adenosine agonist AMP and allergen-induced airway responsiveness and cellular influx in a mouse model of asthma." J.Pharmacol.Exp.Ther. 320.3 (2007): 1246-51.

Nickerson, D. A., V. O. Tobe, and S. L. Taylor. "PolyPhred: automating the detection and genotyping of single nucleotide substitutions using fluorescence-based resequencing." Nucleic Acids Res. 25.14 (1997): 2745-51.

Noto, T., et al. "Role of adenosine and P2 receptors in the penile tumescence in anesthetized dogs." Eur.J.Pharmacol. 425.1 (2001): 51-55.

Novitskiy, S. V., et al. "Adenosine receptors in regulation of dendritic cell differentiation and function." Blood 112.5 (2008): 1822-31.

Ochi, S., et al. "Pathological role of osteoclast costimulation in arthritis-induced bone loss." Proc.Natl.Acad.Sci.U.S.A 104.27 (2007): 11394-99.

Ohene-Frempong, K., et al. "Cerebrovascular accidents in sickle cell disease: rates and risk factors." Blood 91.1 (1998): 288-94.

Okpala, I. "The intriguing contribution of white blood cells to sickle cell disease a red cell disorder." Blood Rev. 18.1 (2004): 65-73. 
Okpala, I., et al. "Relationship between the clinical manifestations of sickle cell disease and the expression of adhesion molecules on white blood cells." Eur.J.Haematol. 69.3 (2002): 135-44.

Olah, M. E. and G. L. Stiles. "Adenosine receptor subtypes: characterization and therapeutic regulation." Annu.Rev.Pharmacol.Toxicol. 35 (1995): 581-606.

Orriss, I. R., et al. "Osteoblast responses to nucleotides increase during differentiation." Bone 39.2 (2006): 300-09.

Palmer, T. M. and G. L. Stiles. "Adenosine receptors." Neuropharmacology 34.7 (1995): 683-94.

Palmqvist, P., et al. "IL-6, leukemia inhibitory factor, and oncostatin M stimulate bone resorption and regulate the expression of receptor activator of NFkappa B ligand, osteoprotegerin, and receptor activator of NF-kappa B in mouse calvariae." J.Immunol. 169.6 (2002): 3353-62.

Panther, E., et al. "Expression and function of adenosine receptors in human dendritic cells." FASEB J. 15.11 (2001): 1963-70.

Pavlakis, S. G., et al. "Brain infarction in sickle cell anemia: magnetic resonance imaging correlates." Ann.Neurol. 23.2 (1988): 125-30.

Peachell, P. T. and S. K. Morcos. "Effect of radiographic contrast media on histamine release from human mast cells and basophils." Br.J.Radiol. 71.841 (1998): 24-30.

Peakman, M. C. and S. J. Hill. "Adenosine A2B-receptor-mediated cyclic AMP accumulation in primary rat astrocytes." Br.J.Pharmacol. 111.1 (1994): 191-98.

Pearson, T., et al. "Plasticity of purine release during cerebral ischemia: clinical implications?" J.Cell Mol.Med. 7.4 (2003): 362-75.

Perelman, N., et al. "Placenta growth factor activates monocytes and correlates with sickle cell disease severity." Blood 102.4 (2003): 1506-14.

Persico, A. M., et al. "Adenosine deaminase alleles and autistic disorder: casecontrol and family-based association studies." Am.J.Med.Genet. 96.6 (2000): 784-90.

Phatarpekar, P. V., J. Wen, and Y. Xia. "Role of adenosine signaling in penile erection and erectile disorders." J.Sex Med. 7.11 (2010): 3553-64. 
Pilitsis, J. G. and H. K. Kimelberg. "Adenosine receptor mediated stimulation of intracellular calcium in acutely isolated astrocytes." Brain Res. 798.1-2 (1998): 294-303.

Platt, O. S., et al. "Mortality in sickle cell disease. Life expectancy and risk factors for early death." N.Engl.J.Med. 330.23 (1994): 1639-44.

Polosa, R. "Adenosine-receptor subtypes: their relevance to adenosinemediated responses in asthma and chronic obstructive pulmonary disease." Eur.Respir.J. 20.2 (2002): 488-96.

Polosa, R. and M. R. Blackburn. "Adenosine receptors as targets for therapeutic intervention in asthma and chronic obstructive pulmonary disease." Trends Pharmacol.Sci. 30.10 (2009): 528-35.

Ponnoth, D. S. and Mustafa S. Jamal. "Adenosine receptors and vascular inflammation." Biochim.Biophys.Acta (2010).

Porter, J. T. and K. D. McCarthy. "Adenosine receptors modulate [Ca2+]i in hippocampal astrocytes in situ." J.Neurochem. 65.4 (1995): 1515-23.

Ralevic, V. and G. Burnstock. "Receptors for purines and pyrimidines." Pharmacol.Rev. 50.3 (1998): 413-92.

Redding-Lallinger, R. "Questions in the management of sickle cell." J.Pediatr. 149.5 (2006): 595-97.

Redding-Lallinger, R. and C. Knoll. "Sickle cell disease--pathophysiology and treatment." Curr.Probl.Pediatr.Adolesc.Health Care 36.10 (2006): 34676.

Resta,R., Yamashita,Y., \& Thompson,L.F. Ecto-enzyme and signaling functions of lymphocyte CD73". Immunol.Rev., (1998) 161, 95-109.

Retey, J. V., et al. "A functional genetic variation of adenosine deaminase affects the duration and intensity of deep sleep in humans." Proc.Natl.Acad.Sci.U.S.A 102.43 (2005): 15676-81.

Rogachev, B., et al. "Adenosine is upregulated during peritonitis and is involved in downregulation of inflammation." Kidney Int. 70.4 (2006): 675-81.

Roman, J., et al. "Adenosine induces fibronectin expression in lung epithelial cells: implications for airway remodeling." Am.J.Physiol Lung Cell Mol.Physiol 290.2 (2006): L317-L325.

Rongen, G. A., et al. "Cardiovascular pharmacology of purines." Clin.Sci.(Lond) 92.1 (1997): 13-24. 
Rongen, G. A., et al. "Presynaptic inhibition of norepinephrine release from sympathetic nerve endings by endogenous adenosine." Hypertension 27.4 (1996): 933-38.

Rotter, M., et al. "Molecular crowding limits the role of fetal hemoglobin in therapy for sickle cell disease." J.Mol.Biol. 347.5 (2005): 1015-23.

Rotter, M. A., et al. "Heterogeneous nucleation in sickle hemoglobin: experimental validation of a structural mechanism." Biophys.J. 89.4 (2005): 2677-84.

Rounds, S., et al. "Mechanism of extracellular ATP- and adenosine-induced apoptosis of cultured pulmonary artery endothelial cells." Am.J.Physiol 275.2 Pt 1 (1998): L379-L388.

Ryzhov, S., et al. "Adenosine-activated mast cells induce IgE synthesis by B lymphocytes: an A2B-mediated process involving Th2 cytokines IL-4 and IL-13 with implications for asthma." J.Immunol. 172.12 (2004): 7726-33.

Ryzhov, S., et al. "Effect of A2B adenosine receptor gene ablation on proinflammatory adenosine signaling in mast cells." J.Immunol. 180.11 (2008): 7212-20.

Saccucci, P., et al. "Association of adenosine deaminase polymorphism with mild mental retardation." J.Child Neurol. 21.9 (2006): 753-56.

Safranow, K., et al. "ADA*2 allele of the adenosine deaminase gene may protect against coronary artery disease." Cardiology 108.4 (2007): 27581.

Saleh, A. W., H. F. Hillen, and A. J. Duits. "Levels of endothelial, neutrophil and platelet-specific factors in sickle cell anemia patients during hydroxyurea therapy." Acta Haematol. 102.1 (1999): 31-37.

Salmon, J. E., et al. "Human mononuclear phagocytes express adenosine A1 receptors. A novel mechanism for differential regulation of Fc gamma receptor function." J.Immunol. 151.5 (1993): 2775-85.

Salmon, J. E. and B. N. Cronstein. "Fc gamma receptor-mediated functions in neutrophils are modulated by adenosine receptor occupancy. A1 receptors are stimulatory and A2 receptors are inhibitory." J.Immunol. 145.7 (1990): 2235-40.

Santoli, F., et al. "Pulmonary function in sickle cell disease with or without acute chest syndrome." Eur.Respir.J. 12.5 (1998): 1124-29. 
Statistical Analyses System - SAS. User's guide.Version 9.13. Cary: SAS Institute, 2003.

Sauer, A. V., et al. "ADA-deficient SCID is associated with a specific microenvironment and bone phenotype characterized by RANKL/OPG imbalance and osteoblast insufficiency." Blood 114.15 (2009): 3216-26.

Schett, G. "Cells of the synovium in rheumatoid arthritis. Osteoclasts." Arthritis Res.Ther. 9.1 (2007): 203.

Seidman, C., F. Kirkham, and S. Pavlakis. "Pediatric stroke: current developments." Curr.Opin.Pediatr. 19.6 (2007): 657-62.

Serjeant, G. R. "The emerging understanding of sickle cell disease." Br.J.Haematol. 112.1 (2001): 3-18.

Sitkovsky,M. \& Lukashev,D. "Regulation of immune cells by local-tissue oxygen tension: HIF1 alpha and adenosine receptors". Nat.Rev.Immunol., (2005) 5, 712-721.

Shimegi, S. "Mitogenic action of adenosine on osteoblast-like cells, MC3T3-E1." Calcif.Tissue Int. 62.5 (1998): 418-25.

Shin, H. I., et al. "Gp130-mediated signaling is necessary for normal osteoblastic function in vivo and in vitro." Endocrinology 145.3 (2004): 1376-85.

shley-Koch, A. E., et al. "Identification of genetic polymorphisms associated with risk for pulmonary hypertension in sickle cell disease." Blood 111.12 (2008): 5721-26.

Sitaraman, S. V., et al. "Neutrophil-epithelial crosstalk at the intestinal lumenal surface mediated by reciprocal secretion of adenosine and IL-6." J.Clin.Invest 107.7 (2001): 861-69.

Soliman, A. T., et al. "Decreased bone mineral density in prepubertal children with sickle cell disease: correlation with growth parameters, degree of siderosis and secretion of growth factors." J.Trop.Pediatr. 44.4 (1998): 194-98.

Spicuzza, L., C. Bonfiglio, and R. Polosa. "Research applications and implications of adenosine in diseased airways." Trends Pharmacol.Sci. 24.8 (2003): 409-13.

Steinberg, M. H. "Genetic etiologies for phenotypic diversity in sickle cell anemia." ScientificWorldJournal. 9 (2009): 46-67. 
Steinberg, M. H. and A. H. Adewoye. "Modifier genes and sickle cell anemia." Curr.Opin.Hematol. 13.3 (2006): 131-36.

Steinberg, M. H., et al. "Effect of hydroxyurea on mortality and morbidity in adult sickle cell anemia: risks and benefits up to 9 years of treatment." JAMA 289.13 (2003): 1645-51.

Strouse, J. J., et al. "Hydroxyurea for sickle cell disease: a systematic review for efficacy and toxicity in children." Pediatrics 122.6 (2008): 1332-42.

Stubbs, G., et al. "Adenosine deaminase activity decreased in autism." J.Am.Acad.Child Psychiatry 21.1 (1982): 71-74.

Styles, L. A., et al. "Decrease of very late activation antigen-4 and CD36 on reticulocytes in sickle cell patients treated with hydroxyurea." Blood 89.7 (1997): 2554-59.

Sun, C. X., et al. "Role of A2B adenosine receptor signaling in adenosinedependent pulmonary inflammation and injury." J.Clin.Invest 116.8 (2006): 2173-82.

Takayanagi, H. "Osteoimmunology: shared mechanisms and crosstalk between the immune and bone systems." Nat.Rev.Immunol. 7.4 (2007): 292-304.

Tang, Z., et al. "Polymorphisms in adenosine receptor genes are associated with infarct size in patients with ischemic cardiomyopathy." Clin.Pharmacol.Ther. 82.4 (2007): 435-40.

Tostes, R. C., et al. "Determination of adenosine effects and adenosine receptors in murine corpus cavernosum." J.Pharmacol.Exp.Ther. 322.2 (2007): 678-85.

Toulmond, S., et al. "Local infusion of interleukin-6 attenuates the neurotoxic effects of NMDA on rat striatal cholinergic neurons." Neurosci.Lett. 144.1-2 (1992): 49-52.

Traina, F., et al. "Chronic liver abnormalities in sickle cell disease: a clinicopathological study in 70 living patients." Acta Haematol. 118.3 (2007): 129-35.

Tsai, J. C., et al. "Promotion of vascular smooth muscle cell growth by homocysteine: a link to atherosclerosis." Proc.Natl.Acad.Sci.U.S.A 91.14 (1994): 6369-73.

Turhan, A., et al. "Primary role for adherent leukocytes in sickle cell vascular occlusion: a new paradigm." Proc.Natl.Acad.Sci.U.S.A 99.5 (2002): 3047-51. 
Van, Belle H., F. Goossens, and J. Wynants. "Formation and release of purine catabolites during hypoperfusion, anoxia, and ischemia." Am.J.Physiol 252.5 Pt 2 (1987): H886-H893.

VanderJagt, D. J., et al. "Assessment of the bone status of Nigerian children and adolescents with sickle cell disease using calcaneal ultrasound and serum markers of bone metabolism." Calcif.Tissue Int. 71.2 (2002): 13340.

Varani, K., et al. "Alteration of adenosine receptors in patients with chronic obstructive pulmonary disease." Am.J.Respir.Crit Care Med. 173.4 (2006): 398-406.

Vekilov, P. G. "Sickle-cell haemoglobin polymerization: is it the primary pathogenic event of sickle-cell anaemia?" Br.J.Haematol. 139.2 (2007): 173-84.

Vendramini, E. C., et al. "Lung function and airway hyperresponsiveness in adult patients with sickle cell disease." Am.J.Med.Sci. 332.2 (2006): 6872.

Verlaan, D. J., et al. "Allele-specific chromatin remodeling in the ZPBP2/GSDMB/ORMDL3 locus associated with the risk of asthma and autoimmune disease." Am.J.Hum.Genet. 85.3 (2009): 377-93.

Vermes, C., et al. "Shedding of the interleukin-6 (IL-6) receptor (gp80) determines the ability of IL-6 to induce gp130 phosphorylation in human osteoblasts." J.Biol.Chem. 277.19 (2002): 16879-87.

Vichinsky, E. P., et al. "Causes and outcomes of the acute chest syndrome in sickle cell disease. National Acute Chest Syndrome Study Group." N.Engl.J.Med. 342.25 (2000): 1855-65.

Vichinsky, E. P., et al. "The perioperative complication rate of orthopedic surgery in sickle cell disease: report of the National Sickle Cell Surgery Study Group." Am.J.Hematol. 62.3 (1999): 129-38.

Villagra, J., et al. "Platelet activation in patients with sickle disease, hemolysisassociated pulmonary hypertension, and nitric oxide scavenging by cellfree hemoglobin." Blood 110.6 (2007): 2166-72.

Walker, B. A., et al. "Adenosine A3 receptor expression and function in eosinophils." Am.J.Respir.Cell Mol.Biol. 16.5 (1997): 531-37.

Wardas, J. "Neuroprotective role of adenosine in the CNS." Pol.J.Pharmacol. 54.4 (2002): 313-26. 
Ware, H. E., et al. "Sickle cell disease and silent avascular necrosis of the hip." J.Bone Joint Surg.Br. 73.6 (1991): 947-49.

Williams, T. N. "Red blood cell defects and malaria." Mol.Biochem.Parasitol. 149.2 (2006): 121-27.

Winn, H. R., R. Rubio, and R. M. Berne. "Brain adenosine production in the rat during 60 seconds of ischemia." Circ.Res. 45.4 (1979): 486-92.

Wun, T., et al. "Activated monocytes and platelet-monocyte aggregates in patients with sickle cell disease." Clin.Lab Haematol. 24.2 (2002): 81-88.

Wun, T., et al. "Platelet activation and platelet-erythrocyte aggregates in patients with sickle cell anemia." J.Lab Clin.Med. 129.5 (1997): 507-16.

Xaus, J., et al. "IFN-gamma up-regulates the A2B adenosine receptor expression in macrophages: a mechanism of macrophage deactivation." J.Immunol. 162.6 (1999): 3607-14.

Yang, D., et al. "The A2B adenosine receptor protects against inflammation and excessive vascular adhesion." J.Clin.Invest 116.7 (2006): 1913-23.

Yonezawa, A., et al. "[Adenosine and adenosine triphosphate]." Nippon Rinsho 60 Suppl 6 (2002): 52-56.

Young, H. W., et al. "A3 adenosine receptor signaling contributes to airway inflammation and mucus production in adenosine deaminase-deficient mice." J.Immunol. 173.2 (2004): 1380-89.

Zeng, D., et al. "Heparin attenuates symptoms and mast cell degranulation induced by AMP nasal provocation." J.Allergy Clin.Immunol. 114.2 (2004): 316-20.

Zhao, P., et al. "Hypoxia suppresses the production of MMP-9 by human monocyte-derived dendritic cells and requires activation of adenosine receptor A2b via cAMP/PKA signaling pathway." Mol.Immunol. 45.8 (2008): 2187-95.

Zhong, $\mathrm{H}$., et al. "A(2B) adenosine receptors increase cytokine release by bronchial smooth muscle cells." Am.J.Respir.Cell Mol.Biol. 30.1 (2004): 118-25.

Zhong, H., et al. "Synergy between A2B adenosine receptors and hypoxia in activating human lung fibroblasts." Am.J.Respir.Cell Mol.Biol. 32.1 (2005): 2-8. 
Zhong, $H_{\text {. }}$, et al. "A2B adenosine receptors induce IL-19 from bronchial epithelial cells, resulting in TNF-alpha increase." Am.J.Respir.Cell Mol.Biol. 35.5 (2006): 587-92.

Zimmermann, K., P. W. Reeh, and B. Averbeck. "ATP can enhance the protoninduced CGRP release through P2Y receptors and secondary PGE(2) release in isolated rat dura mater." Pain 97.3 (2002): 259-65.

Zoroglu, S. S., et al. "Increased oxidative stress and altered activities of erythrocyte free radical scavenging enzymes in autism." Eur.Arch.Psychiatry Clin.Neurosci. 254.3 (2004): 143-47. 
8. ANEXOS 


\subsection{Anexo 1. Termo de Consentimento Livre e Esclarecido}

\section{HOSPITAL DAS CLÍNICAS DA FACULDADE DE MEDICINA DE RIBEIRAO PRETO DA UNIVERSIDADE DE SÃO PAULO}

\section{TERMO DE CONSENTIMENTO LIVRE E ESCLARECIDO}

Você está sendo convidado(a) a participar desta pequisa. A participação é voluntária. Após ser esclarecido(a) sobre as informações contidas neste documento, no caso de aceitar fazer parte do estudo, assine ao final deste documento.

Nome da Pesquisa: "Identificação de Polimorfismos nos Receptores de Adenosina e suas Associações com Diferentes Características Fisiopatológicas dos Pacientes com Anemia Falciforme"

Pesquisadores Responsáveis: Prof. Dr. Rodrigo Alexandre Panepucci e Carolina Dias Carlos.

\section{Descrição da Pesquisa:}

Na Anemia Falciforme, a oclusão de vasos (VO) e isquemia tecidual (crises dolorosas) caracterizam a doença. Alem das crises dolorosas, os pacientes falciformes apresentam outras manifestações clínicas como o priapismo, baixa resistência imune e certas complicações pulmonares.

Estudos recentes demonstraram que níveis elevados de uma substância chamada adenosina podem estar ligados a algumas das manifestações clínicas da Anemia Falciforme, como o priaprismo, a hiperresponsividade das vias aéreas assim como a inflamação e a fibrose pulmonar. A atuação da adenosina pode ocorrer através de receptores, encontrados em diferentes tecidos e órgãos dos pacientes. Estes receptores interpretam os níveis de adenosina resultando em diferentes manifestações nos tecidos e órgãos. Estes receptores podem ter diferenças (polimorfismos) de paciente para paciente e isto poderia explicar porque alguns pacientes apresentam sintomas da doença de maneira mais acentuada que outros. Adicionalmente, os níveis de adenosina podem ser reduzidos por uma enzima (Adenosina Deaminase - ADA), que também pode diferir de paciente a paciente. 
Com isto em vista, este projeto propõe identificar os polimorfismos nestes receptores de adenosina e na enzima ADA que possam estar ligadas a diferentes manifestações clinicas dos pacientes.

Assim, a determinação de uma potencial associação destes polimorfismos com diferentes características clínicas pode levar a um melhor entendimento dos processos fisiopatológicos da anemia falciforme.

Caso o paciente concorde em colaborar com esta pesquisa, o paciente simplesmente terá o sangue periférico coletado por punção de veia (cerca de 10 a 15 $\mathrm{mL}$ ), de forma semelhante à coleta de sangue para realização de exame de sangue. Desta forma, nenhum procedimento estranho ou danoso ao paciente será realizado. Mesmo que o paciente não concorde em participar da pesquisa, seu atendimento se dará da mesma forma.

Esta pesquisa pode beneficiar os pacientes portadores de Anemia Falciforme, pois pode eventualmente ajudar na identificação de pacientes de risco, possibilitando um manejo racional dos mesmos, em termos de cuidados específicos, ou ainda, levar ao futuro desenvolvimento de terapias alternativas para os pacientes.

O paciente não terá nenhuma despesa proveniente da participação nesta pesquisa.

Caso o paciente não concorde em participar desta pesquisa, isto NÃO irá alterar de forma alguma o seu atendimento.

Assim se desejar participar desta pesquisa, Ihe asseguramos:

a) A garantia de receber a resposta a qualquer pergunta ou esclarecimento de qualquer dúvida a respeito dos procedimentos, riscos, benefícios e de outras situações relacionadas com a pesquisa e o tratamento a que serei submetido;

b) A liberdade de retirar o meu consentimento e deixar de participar do estudo, a qualquer momento, sem que isso traga prejuízo à continuidade do meu tratamento;

c) A segurança de que não serei identificado e que será mantido o caráter confidencial da informação relacionada à minha privacidade;

d) O compromisso de que me será prestada informação atualizada durante o estudo, ainda que esta possa afetar a minha vontade de continuar dele participando; 
e) O compromisso de que serei devidamente acompanhado e assistido durante todo o período de minha participação no projeto, bem como de que será garantida a continuidade do meu tratamento, após a conclusão dos trabalhos de pesquisa.

Nome: Assinatura:

(Pesquisador)

Fui devidamente esclarecido e declaro que concordo inteiramente com as condições que me foram apresentadas e que livremente manifesto a minha vontade em participar do referido projeto.

Nome: Assinatura:

(Paciente ou Responsável)

Ribeirão Preto, de de 201

Qualquer dúvida sobre esta pesquisa, entrar em contato pelo telefone 3602-2223 com:

Dr Rodrigo Alexandre Panepucci ou Sra. Carolina Dias Carlos.

(Laboratório de hematologia, Hospital das Clínicas, FMRP-USP). 


\subsection{Anexo 2. Frequências Alélicas}

Freqüências alélicas dos polimorfismos nos genes ADORA1,ADORA 2B, ADORA 3 e ADA para STA, HP, priapismo, alterações ósseas e estenose/AVC e suas probabilidades de associação entre afetados e não afetados.

\begin{tabular}{cccccc}
\hline \multirow{2}{*}{ Gene } & SNP & Alelo & CTR ( $\mathbf{n = 1 6 5 )}$ & STA $(\mathbf{n}=\mathbf{4 2})$ & P valor \\
CTR vs. STA \\
\hline ADORA 1 & rs16851030 & $\mathrm{C}$ & 0.930 & 0.869 & 0.112 \\
& & $\mathrm{~T}$ & 0.06 & 0.131 & \\
ADORA 3 & rs35511654 & $\mathrm{G}$ & 0.924 & 0.928 & 1.0 \\
& & $\mathrm{~T}$ & 0.075 & 0.071 & \\
ADORA 2B & 968 G>T & $\mathrm{G}$ & 0.921 & 0.881 & 0.271 \\
& & $\mathrm{~T}$ & 0.078 & 0.119 & \\
ADORA 2B & \multirow{2}{*}{ 1007 C>T } & $\mathrm{C}$ & 0.897 & 0.809 & $0.032^{*}$ \\
& & $\mathrm{~T}$ & 0.095 & 0.190 & \\
ADA & $\mathrm{G} 22 \mathrm{~A}$ & $\mathrm{G}$ & 0.969 & 0.976 & 1.0 \\
& & $\mathrm{~A}$ & 0.030 & 0.023 & \\
\hline
\end{tabular}

\begin{tabular}{|c|c|c|c|c|c|}
\hline \multirow[b]{2}{*}{ Gene } & \multirow[b]{2}{*}{ SNP } & \multirow[b]{2}{*}{ Alelo } & \multicolumn{2}{|c|}{ Frequência Alélica } & \multirow{2}{*}{$\begin{array}{c}\text { p valor } \\
\text { CTR vs. H.P }\end{array}$} \\
\hline & & & CTR $(n=168)$ & H.P $(n=39)$ & \\
\hline \multirow[t]{2}{*}{ ADORA 1} & rs16851030 & C & 0.913 & 0.935 & 0.650 \\
\hline & & $T$ & 0.08 & 0.06 & \\
\hline \multirow[t]{2}{*}{ ADORA 3} & rs35511654 & G & 0.928 & 0.910 & 0.629 \\
\hline & & $T$ & 0.071 & 0.089 & \\
\hline \multirow[t]{2}{*}{ ADORA 2B } & $968 \mathrm{G}>\mathrm{T}$ & G & 0.922 & 0.871 & 0.174 \\
\hline & & $T$ & 0.077 & 0.128 & \\
\hline \multirow[t]{2}{*}{ ADORA 2B } & $1007 \mathrm{C}>\mathrm{T}$ & C & 0.892 & 0.820 & 0.115 \\
\hline & & $T$ & 0.107 & 0.179 & \\
\hline \multirow[t]{2}{*}{ ADA } & G $22 \mathrm{~A}$ & G & 0.970 & 0.974 & 1.0 \\
\hline & & $A$ & 0.029 & 0.025 & \\
\hline
\end{tabular}

\section{Frequência Alélica}

\begin{tabular}{cccccc} 
Gene & SNP & Alelo & CTR $(\mathbf{n}=\mathbf{6 9})$ & PRIAP. $(\mathbf{n}=\mathbf{2 4})$ & $\begin{array}{c}\text { CTR vs. } \\
\text { PRIAP }\end{array}$ \\
\hline ADORA 1 & rs16851030 & C & 0.898 & 0.916 & 0.783 \\
& & T & 0.101 & 0.083 & \\
ADORA 3 & rs35511654 & G & 0.934 & 0.9375 & 0.783 \\
& & T & 0.065 & 0.062 & \\
ADORA 2B & 968 G>T & G & 0.907 & 0.934 & 0.764 \\
& & T & 0.092 & 0.092 & \\
ADORA 2B & \multirow{2}{*}{$1007 \mathrm{C}>\mathrm{T}$} & $\mathrm{C}$ & 0.826 & 0.913 & 0.164 \\
& & $\mathrm{~T}$ & 0.173 & 0.087 &
\end{tabular}




\begin{tabular}{|c|c|c|c|c|c|}
\hline \multirow[t]{2}{*}{ ADA } & \multirow[t]{2}{*}{ G $22 \mathrm{~A}$} & $\mathrm{G}$ & 0.977 & 0.958 & \multirow[t]{2}{*}{0.606} \\
\hline & & $A$ & 0.022 & 0.041 & \\
\hline
\end{tabular}

\begin{tabular}{|c|c|c|c|c|c|}
\hline \multirow[b]{2}{*}{ Gene } & \multirow[b]{2}{*}{ SNP } & \multirow[b]{2}{*}{ Alelo } & \multicolumn{2}{|c|}{ Frequência Alélica } & \multirow{2}{*}{$\begin{array}{c}\text { p valor } \\
\text { CTR vs.ALT.OSS }\end{array}$} \\
\hline & & & $\operatorname{CTR}(n=131)$ & ALT.OSS $(n=63)$ & \\
\hline \multirow[t]{2}{*}{ ADORA 1} & rs16851030 & C & 0.911 & 0.928 & 0.695 \\
\hline & & $\mathrm{T}$ & 0.088 & 0.071 & \\
\hline \multirow[t]{2}{*}{ ADORA 3} & rs35511654 & G & 0.923 & 0.936 & 0.686 \\
\hline & & $\mathrm{T}$ & 0.076 & 0.063 & \\
\hline \multirow[t]{2}{*}{ ADORA 2B } & $968 \mathrm{G}>\mathrm{T}$ & G & 0.884 & 0.976 & $0.0012^{*}$ \\
\hline & & $\mathrm{T}$ & 0.115 & 0.023 & \\
\hline \multirow[t]{2}{*}{ ADORA 2B } & $1007 \mathrm{C}>\mathrm{T}$ & C & 0.842 & 0.960 & $0.00029 *$ \\
\hline & & $\mathrm{T}$ & 0.157 & 0.039 & \\
\hline \multirow[t]{2}{*}{ ADA } & G $22 \mathrm{~A}$ & G & 0.973 & 0.959 & 0.531 \\
\hline & & A & 0.026 & 0.041 & \\
\hline
\end{tabular}

\begin{tabular}{|c|c|c|c|c|c|}
\hline \multirow[b]{2}{*}{ Gene } & \multirow[b]{2}{*}{ SNP } & \multicolumn{3}{|c|}{ Frequência Alélica } & \multirow{2}{*}{$\begin{array}{l}\text { p valor } \\
\text { CTR vs. AVC }\end{array}$} \\
\hline & & Alelo & CTR (n=178) & ESTENOSE/ AVC $(n=42)$ & \\
\hline \multirow[t]{2}{*}{ ADORA 1} & rs16851030 & $\mathrm{C}$ & 0.921 & 0.892 & 0.511 \\
\hline & & $\mathrm{T}$ & 0.078 & 0.107 & \\
\hline \multirow[t]{2}{*}{ ADORA 3} & rs35511654 & G & 0.927 & 0.916 & 0.818 \\
\hline & & $\mathrm{T}$ & 0.073 & 0.083 & \\
\hline \multirow[t]{2}{*}{ ADORA 2B } & $968 \mathrm{G}>\mathrm{T}$ & G & 0.904 & 0.964 & 0.079 \\
\hline & & $\mathrm{T}$ & 0.095 & 0.035 & \\
\hline \multirow[t]{2}{*}{ ADORA 2B } & $1007 \mathrm{C}>\mathrm{T}$ & C & 0.870 & 0.940 & 0.063 \\
\hline & & $\mathrm{T}$ & 0.129 & 0.059 & \\
\hline \multirow[t]{2}{*}{ ADA } & G $22 \mathrm{~A}$ & G & 0.969 & 0.988 & 0.476 \\
\hline & & A & 0.030 & 0.011 & \\
\hline
\end{tabular}




\subsection{Análises Adicionais}

Freqüências alélicas dos polimorfismos nos genes TGFBR3 e ORMDL3 para STA, HP, priapismo, alterações ósseas e estenose/AVC e suas probabilidades de associação entre afetados e não afetados.

\begin{tabular}{cccccc}
\hline & & & \multicolumn{2}{c}{ Frequência Alélica } & p valor \\
Gene & SNP & Alelo & CTR $(\mathbf{n}=\mathbf{1 6 5})$ & STA $(\mathbf{n}=\mathbf{4 2})$ & CTR vs. STA \\
\hline TGFBR3 & rs7526590 & A & 0.839 & 0.857 & 0.741 \\
& & T & 0.160 & 0.142 & \\
ORMDL3 & rs7216389 & T & 0.690 & 0.714 & 0.695 \\
& & C & 0.309 & 0.285 & \\
\hline
\end{tabular}

\begin{tabular}{cccccc}
\hline \multirow{2}{*}{ Gene } & & & \multicolumn{2}{c}{ Frequência Genotípica } & p valor \\
TGFBR3 & SNP & Genótipo & CTR $(\mathbf{n}=\mathbf{1 6 5})$ & STA $(\mathbf{n}=\mathbf{4 2})$ & CTR vs. STA \\
\hline & rs7526590 & AA & 0.703 & 0.738 & 0.735 \\
& & AT & 0.272 & 0.238 & \\
ORMDL3 & TS7216389 & TT & 0.024 & 0.023 & \\
& & 0.509 & 0.5 & 0.712 \\
& & TC & 0.363 & 0.428 & \\
& & CC & 0.127 & 0.071 & \\
\hline
\end{tabular}

\begin{tabular}{cccccc}
\hline & & \multicolumn{2}{c}{ Frequência Alélica } & p valor \\
Gene & SNP & Alelo & CTR $(\mathbf{n}=\mathbf{1 6 8})$ & H.P $(\mathbf{n}=\mathbf{3 9})$ & CTR vs. H.P \\
\hline TGFBR3 & rs7526590 & A & 0.851 & 0.807 & 0.389 \\
& & T & 0.148 & 0.192 & \\
ORMDL3 & rs7216389 & T & 0.705 & 0.653 & 0.415 \\
& & C & 0.294 & 0.346 & \\
\hline
\end{tabular}

\begin{tabular}{|c|c|c|c|c|c|}
\hline \multirow[b]{2}{*}{ Gene } & \multirow[b]{2}{*}{ SNP } & \multirow{2}{*}{$\begin{array}{c}\text { Genótip } \\
\text { o } \\
\end{array}$} & \multicolumn{2}{|c|}{ Frequência Genotípica } & \multirow{2}{*}{$\begin{array}{l}\text { p valor } \\
\text { CTR vs. H.P }\end{array}$} \\
\hline & & & CTR ( $n=168)$ & H.P $(n=39)$ & \\
\hline \multirow[t]{3}{*}{ TGFBR3 } & rs7526590 & AA & 0.726 & 0.641 & 0.382 \\
\hline & & AT & 0.25 & 0.333 & \\
\hline & & TT & 0.023 & 0.025 & \\
\hline \multirow[t]{3}{*}{ ORMDL3 } & rs7216389 & TT & 0.511 & 0.487 & 0.451 \\
\hline & & $\mathrm{TC}$ & 0.386 & 0.333 & \\
\hline & & $\mathrm{CC}$ & 0.101 & 0.179 & \\
\hline
\end{tabular}




\begin{tabular}{|c|c|c|c|c|c|}
\hline \multirow[b]{2}{*}{ Gene } & \multirow[b]{2}{*}{ SNP } & \multirow[b]{2}{*}{ Alelo } & \multicolumn{2}{|c|}{ Frequência Alélica } & \multirow{2}{*}{$\begin{array}{l}\text { p valor } \\
\text { CTR vs. } \\
\text { PRIAP }\end{array}$} \\
\hline & & & $\operatorname{CTR}(n=69)$ & PRIAP. $(n=24)$ & \\
\hline \multirow[t]{2}{*}{ TGFBR3 } & rs7526590 & $A$ & 0.833 & 0.729 & 0.133 \\
\hline & & $\mathrm{T}$ & 0.166 & 0.270 & \\
\hline \multirow[t]{2}{*}{ ORMDL3 } & rs7216389 & $T$ & 0.735 & 0.717 & 0.847 \\
\hline & & C & 0.264 & 0.282 & \\
\hline
\end{tabular}

\begin{tabular}{cccccc}
\hline & & & \multicolumn{2}{c}{ Frequência Genotípica } & p valor \\
Gene & SNP & Genótipo & CTR $(\mathbf{n}=69)$ & PRIAP. $(\mathbf{n}=\mathbf{2 4})$ & PRIAP \\
\hline TGFBR3 & rs7526590 & AA & 0.681 & 0.541 & 0.134 \\
& & AT & 0.304 & 0.375 & \\
& & TT & 0.014 & 0.083 & \\
ORMDL3 & rs7216389 & TT & 0.544 & 0.434 & 0.843 \\
& & TC & 0.382 & 0.565 & \\
& & CC & 0.073 & 0 & \\
\hline
\end{tabular}

\begin{tabular}{cccccc}
\hline & & & \multicolumn{2}{c}{ Frequência Alélica } & $\begin{array}{c}\text { p valor } \\
\text { CTR }\end{array}$ \\
Gene & SNP & Alelo & CTR $(\mathbf{n}=131)$ & ALT.OSS ( $\mathbf{n}=\mathbf{6 3})$ & vs.ALT.OSS \\
\hline TGFBR3 & rs7526590 & A & 0.846 & 0.841 & 1.0 \\
& & T & 0.153 & 0.158 & \\
ORMDL3 & rs7216389 & T & 0.687 & 0.698 & 0.907 \\
& & C & 0.313 & 0.301 & \\
\hline
\end{tabular}

\begin{tabular}{cccccc}
\hline & & & \multicolumn{2}{c}{ Frequência Genotípica } & $\begin{array}{c}\text { p valor } \\
\text { CTR }\end{array}$ \\
Gene & SNP & Genótipo & CTR $(\mathbf{n}=\mathbf{1 3 1})$ & ALT.OSS ( $\mathbf{n}=\mathbf{6 3})$ & vs.ALT.OSS \\
\hline TGFBR3 & rs7526590 & AA & 0.715 & 0.714 & $\mathbf{1 . 0}$ \\
& & AT & 0.261 & 0.253 & \\
ORMDL3 & rs7216389 & TT & 0.023 & 0.031 & \\
& & TT & 0.503 & 0.492 & 0.913 \\
& & TC & 0.366 & 0.412 & \\
\hline
\end{tabular}




\begin{tabular}{|c|c|c|c|c|c|}
\hline Gene & SNP & Alelo & $\begin{array}{l}\text { Frequência } \\
\text { Alélica } \\
\text { CTR ( } n=178)\end{array}$ & ESTENOSE/ AVC $(n=42)$ & $\begin{array}{c}\text { p valor } \\
\text { CTR vs. AVC }\end{array}$ \\
\hline \multirow[t]{2}{*}{ TGFBR3 } & rs7526590 & $A$ & 0.848 & 0.821 & 0.619 \\
\hline & & $\mathrm{T}$ & 0.151 & 0.178 & \\
\hline \multirow[t]{2}{*}{ ORMDL3 } & rs7216389 & $\mathrm{T}$ & 0.696 & 0.654 & 0.518 \\
\hline & & C & 0.303 & 0.345 & \\
\hline
\end{tabular}

\begin{tabular}{cccccc}
\hline & & & \multicolumn{2}{c}{ Frequência Genotípica } & p valor \\
Gene & SNP & Genótipo & CTR ( $\mathbf{n = 1 7 8 )}$ & ESTENOSE/ AVC ( $\mathbf{n = 4 2 )}$ & CTR vs. AVC \\
\hline TGFBR3 & rs7526590 & AA & 0.713 & 0.690 & 0.611 \\
& & AT & 0.269 & 0.261 & \\
ORMDL3 & rs7216389 & TT & 0.016 & 0.047 & \\
& & TT & 0.511 & 0.452 & \\
& & TC & 0.370 & 0.404 & \\
& & CC & 0.117 & 0.142 & \\
\hline
\end{tabular}


Página | 155 